This is the peer reviewed version of the following article:

Mrózek, O., Vinklárek, J., Růžičková, Z. and Honzíček, J. (2016), Indenyl Compounds with Constrained Hapticity: The Effect of Strong Intramolecular Coordination. Eur. J. Inorg. Chem., 2016: 5250-5264. doi:10.1002/ejic.201601029

This article may be used for non-commercial purposes in accordance With Wiley-VCH Terms and Conditions for self-archiving".

This postprint version is available from http://hdl.handle.net/10195/67606 


\title{
Indenyl compounds with constrained hapticity: effect of strong intramolecular coordination.
}

\author{
Ondřej Mrózek, ${ }^{[a]}$ Jaromír Vinklárek, ${ }^{[a]} Z^{[d e n ̌ k a ~ R u ̊ z ̌ i c ̌ k o v a ́, ~}{ }^{[a]}$ and Jan Honzíček ${ }^{*[b]}$
}

\begin{abstract}
A series of cyclopentadienyl and indenyl molybdenum(II) compounds with intramolecularly coordinated pyridine arm, including scorpionate-like species bearing two irreversibly coordinated arms on indenyl core, was synthesized and characterized. All presented structural types were confirmed by $\mathrm{X}$-ray diffraction analysis. Due to $\pi$-basicity of pyridine, the intramolecular interaction is considerably stronger than in case of analogous species bearing tertiary amines in the side chain. Although the starting compounds for syntheses are isostructural, the reaction outcomes differ considerably. The cyclopentadienyl precursor gives a pentacoordinated $\eta^{5}: K N$-compound while the indenyl analogue produces a hexacoordinated species with unprecedented $\eta^{3}: k N$-coordination mode of the indenyl ligand representing an unusual example of so-called indenyl effect. The unusually high stability of $\eta^{3}: k N$-coordination compounds toward $\eta^{3}$ to $\eta^{5}$ haptotropic rearrangement was clarified by theoretical calculations. As the strong intramolecular interaction prevents rotation of indenyl, it cannot reach a conformation suitable for $\eta^{3}$ to $\eta^{5}$ rearrangement. As a result, the low hapticity is effectively locked.
\end{abstract}

\section{Introduction}

Cyclopentadienyl compounds of the transition metals attract considerable attention since ferrocene, $\left(\eta^{5}-\mathrm{Cp}\right)_{2} \mathrm{Fe}\left(\mathrm{Cp}=\mathrm{C}_{5} \mathrm{H}_{5}\right)$, was discovered in early 1950's. ${ }^{[1]}$ In the last decade, an increasing number of new ring-substituted cyclopentadienyl compounds has appeared in the literature. ${ }^{[2]}$ The variations in cyclopentadienyl ligand periphery often result in dramatic changes in physical, chemical and biological properties of the corresponding compounds. ${ }^{[3]}$ These changes can be, in particular cases, attributed to electronic and steric effects caused by the partial or full replacement of the hydrogen atoms by other groups. ${ }^{[4]}$

A formal replacement of the cyclopentadienyl ligand with indenyl, a congener with annulated benzene ring ( $I n d=\mathrm{C}_{9} \mathrm{H}_{7}$ ), usually accelerates the rates of substitution reactions due to a lower energetic barrier of the haptotropic shift of the $\pi$-ligand. This so-

[a] O. Mrózek, J. Vinklárek, Z. Růžičková

Department of General and Inorganic Chemistry,

Faculty of Chemical Technology, University of Pardubice

Studentská 573, 53210 Pardubice, Czech Republic

[b] J. Honzíček

Institute of Chemistry and Technology of Macromolecular Materials

Faculty of Chemical Technology, University of Pardubice

Studentská 573, 53210 Pardubice, Czech Republic

E-mail: jan.honzicek@upce.cz

Supporting information for this article is given via a link at the end of the document. called "indenyl effect" has been initially attributed to enhanced stability of $\eta^{3}$-intermediates in the association reaction pathway as a consequence of the aromatic gain of the adjacent sixmembered ring. ${ }^{[5]}$ Although this approach is sometimes still accepted, it neglects different thermodynamic stability of $\eta^{5}$-Cp and $\eta^{5}$-Ind species that may play a crucial role in rearrangement as revealed by Veiros et al. ${ }^{[6]}$ They have demonstrated that the acceleration of associative substitution reactions is a direct consequence of the different bonding of the ligands to the metal in $\eta^{5}$ and $\eta^{3}$ coordination modes. Hence, $\left(\eta^{5}-\mathrm{Cp}\right)-\mathrm{M}$ bond is considerably stronger than the $\left(\eta^{5}-\mathrm{Ind}\right)-\mathrm{M}$ while $\left(\eta^{3}-\mathrm{Cp}\right)-\mathrm{M}$ is weaker than $\left(\eta^{3}-\right.$ Ind $)-M$ bond. This is reflected in higher stability of $\eta^{5}$-Cp complexes and $\eta^{3}$-Ind intermediates or transition states proving both a thermodynamic and a kinetic origin of the "indenyl effect" in associative reactions.

Some other mechanisms of the indenyl effect have been proposed for dissociative processes those are naturally not consistent with $\eta^{5}-\eta^{3}$ rearrangement. The electron deficient intermediate could be stabilized by interaction with sixmembered ring. ${ }^{[7]}$ Although nature of the intermediate was not fully clarified, the indenyl ligand could achieve $\eta^{9}$-coordination mode that was documented later on low valent zirconium species. ${ }^{[8]}$ When dissociative substitution reaction involves the "spin forbidden" mechanism, the acceleration could be attributed to lower barrier of spin crossover as recently evidenced on iron(II) compounds. ${ }^{[9]}$

The molybdenum(II) compounds were found to be very suitable for the investigation of $\eta^{5}-\eta^{3}$ rearrangements due to pronounced stability of $\eta^{3}$-indenyl species. Hence, they are often accessible from $\eta^{5}$-species by simple association of $2 \mathrm{e}$ donor into the coordination sphere of molybdenum(II) ${ }^{[10-13]}$ or 2 e reduction of molybdenum(IV) compounds. ${ }^{[14]}$

The aim of the present work is to demonstrate the effect of annulated benzene ring on reactivity of cyclopentadienyl molybdenum compounds bearing strong $\mathrm{N}$-donor in the side chain. The unprecedented structural motif consisting of $\eta^{3}$ indenyl species with strong intramolecular coordination does NOT undergo usual $\eta^{3}-\eta^{5}$ rearrangement due to kinetic stabilization as evidenced by combined experimental/theoretical study. To best of our knowledge, this is the first example of "locking" the species in $\eta^{3}$-coordination mode by intramolecular coordination.

\section{Results and Discussion}

Synthesis of allyl molybdenum precursors

The starting (2-pyridyl)methyl-substituted congeners of [ $\left(\eta^{3}\right.$ $\left.\left.\mathrm{C}_{3} \mathrm{H}_{5}\right)\left(\eta^{5}-\mathrm{Cp}\right) \mathrm{Mo}(\mathrm{CO})_{2}\right]\left(\mathrm{Cp}^{\prime}=\mathrm{Cp}\right.$, Ind) were prepared using a general procedure developed by Faller et al. ${ }^{[15]}$ Functionalized cyclopentadiene $\mathrm{C}_{5} \mathrm{H}_{4} \mathrm{NCH}_{2} \mathrm{C}_{5} \mathrm{H}_{5}$ (3) and indene 3- 
$\left(\mathrm{C}_{5} \mathrm{H}_{4} \mathrm{NCH}_{2}\right) \mathrm{C}_{9} \mathrm{H}_{7}$ (4), necessary for the assembly, were synthesized using reaction of freshly distilled 2(chloromethyl)pyridine with sodium cyclopentadienide (1-Na) and sodium indenide (2-Na), respectively (Scheme 1).
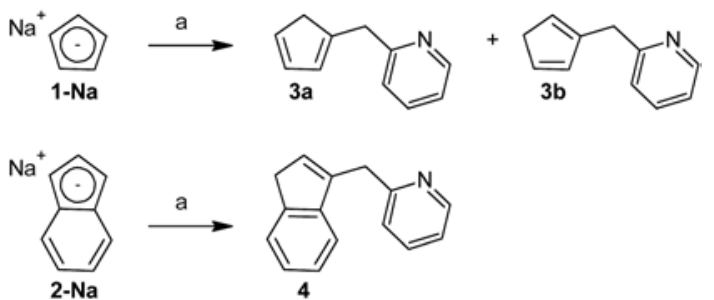

Scheme 1. Synthesis of functionalized cyclopentadiene 3 and indene 4. Reagents: a) $\mathrm{C}_{5} \mathrm{H}_{4} \mathrm{NCH}_{2} \mathrm{Cl} / \mathrm{THF}$.

The indene 4 was further used for synthesis of isotopically substituted derivative 1-D-3- $\left(\mathrm{C}_{5} \mathrm{H}_{4} \mathrm{NCH}_{2}\right) \mathrm{C}_{9} \mathrm{H}_{6}$ (4-D) and 1,3disubstituted indene 1,3- $\left(\mathrm{C}_{5} \mathrm{H}_{4} \mathrm{NCH}_{2}\right)_{2} \mathrm{C}_{9} \mathrm{H}_{6}$ (5), see Scheme 2. ${ }^{1} \mathrm{H}$ and ${ }^{13} \mathrm{C}\left\{{ }^{1} \mathrm{H}\right\}$ NMR spectroscopic measurements reveal that the compound 3 forms a mixture tautomers. At room temperature, 1- and 2-isomer appear in molar ratio $1.2: 1$. In case of compound $\mathbf{4}$, only one tautomer was detected after the distillation purification step. The analytically pure sample of 1,3disubstituted indene $\mathbf{5}$ was obtained after chromatographic purification step. The obtained sample was not contaminated with 1,1-isomer (expected side product) as evidenced by NMR measurements but its appearance in the product crude is not fully disproved. In case of 4-D, the efficiency of labeling was verified by ${ }^{1} \mathrm{H}$ NMR spectroscopy. The spectrum reveals that one hydrogen atom on $s p^{3}$ carbon of indene framework is fully substituted with deuterium.

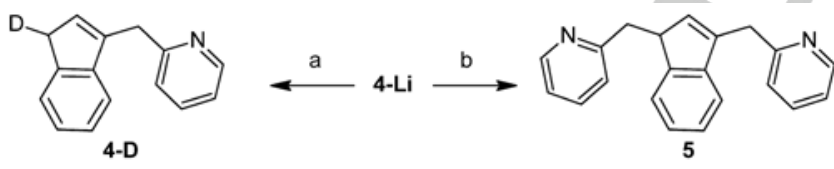

Scheme 2. Synthesis of functionalized indenes 4-D and 5. Reagents: a) $\mathrm{D}_{2} \mathrm{O} / \mathrm{THF}$; b) $\mathrm{C}_{5} \mathrm{H}_{4} \mathrm{NCH}_{2} \mathrm{Cl} / \mathrm{THF}$.
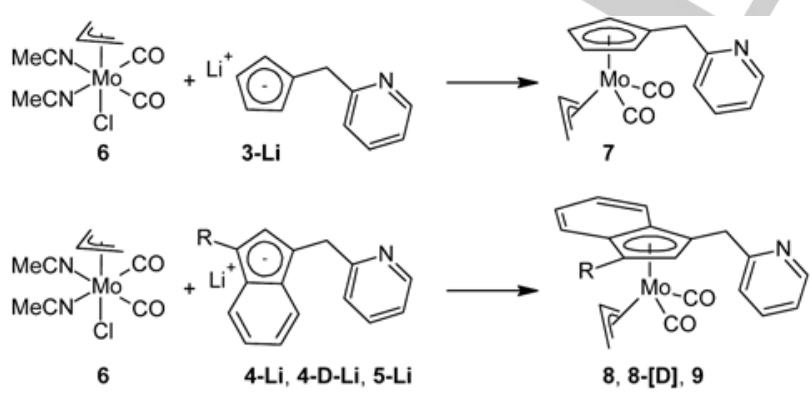

$$
\begin{array}{ll}
\text { 4-Li, 8: } R=H & \text { 4-D-Li: } R=D \\
\text { 5-Li, 9: } R=\mathrm{CH}_{2} \mathrm{C}_{5} \mathrm{H}_{4} \mathrm{~N} & \text { 8-[D]: } R=[D]
\end{array}
$$

Scheme 3. Synthesis of molybdenum compounds 7-9 and 8-[D].
Lithium cyclopentadienide $\mathbf{3}-\mathbf{L i}$, prepared by deprotonation of cyclopentadienes $\mathbf{3}$ with $n$-BuLi, react with chloride complex $\left[\left(\eta^{3}-\right.\right.$ $\left.\mathrm{C}_{3} \mathrm{H}_{5}\right) \mathrm{Mo}(\mathrm{CO})_{2}(\mathrm{NCMe})_{2} \mathrm{Cl}$ (6) to give cyclopentadienyl complex $\left[\left(\eta^{3}-\mathrm{C}_{3} \mathrm{H}_{5}\right)\left(\eta^{5}-\mathrm{C}_{5} \mathrm{H}_{4} \mathrm{NCH}_{2} \mathrm{C}_{5} \mathrm{H}_{4}\right) \mathrm{Mo}(\mathrm{CO})_{2}\right]$ (7), see Scheme 3. Indenyl complexes $\left[\left(\eta^{3}-\mathrm{C}_{3} \mathrm{H}_{5}\right)\left\{\eta^{5}-1-\left(\mathrm{C}_{5} \mathrm{H}_{4} \mathrm{NCH}_{2}\right) \mathrm{C}_{9} \mathrm{H}_{6}\right\} \mathrm{Mo}(\mathrm{CO})_{2}\right]$ (8), $\left[\left(\eta^{3}-\mathrm{C}_{3} \mathrm{H}_{5}\right)\left\{\eta^{5}-1,3-\left(\mathrm{C}_{5} \mathrm{H}_{4} \mathrm{NCH}_{2}\right)_{2} \mathrm{C}_{9} \mathrm{H}_{5}\right\} \mathrm{Mo}(\mathrm{CO})_{2}\right]$ (9) and isotopically labeled species $\left[\left(\eta^{3}-\mathrm{C}_{3} \mathrm{H}_{5}\right)\left\{\eta^{5}-1-\left(\mathrm{C}_{5} \mathrm{H}_{4} \mathrm{NCH}_{2}\right)-3-\right.\right.$ $\left.\left.[\mathrm{D}] \mathrm{C}_{9} \mathrm{H}_{5}\right\} \mathrm{Mo}(\mathrm{CO})_{2}\right]$ (8-[D]) were prepared accordingly starting from indenes 4, 5, and 4-D, respectively.

The alternative route is available for lithium indenide 4-Li. It is given by hydrolithiation reaction of benzofulvene 4' using SuperHydride. The starting 4' was prepared in medium yield by condensation of indene (2) with 2-pyridinecarboxaldehyde. The ${ }^{1} \mathrm{H}$ and ${ }^{13} \mathrm{C}\left\{{ }^{1} \mathrm{H}\right\}$ NMR measurements revealed appearance of the less steric hindered $E$-isomer only. This assignment was confirmed by X-ray diffraction analysis; see Figure 1 . The molecule 4' is almost planar structure. The dihedral angle between plane of the benzofulvene moiety and the pyridine ring is $3.72(5)^{\circ}$.

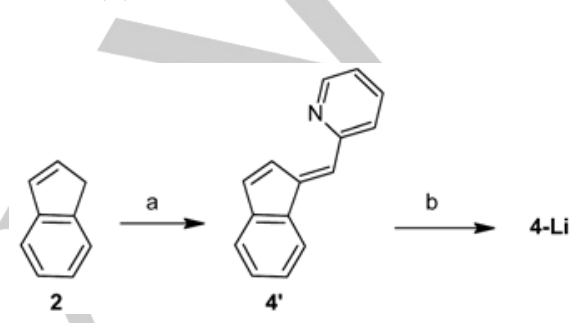

Scheme 4. Synthesis of 4-Li via fulvene intermediate. Reagents: a) $\mathrm{C}_{5} \mathrm{H}_{4} \mathrm{NCHO}, \mathrm{MeONa} / \mathrm{MeOH} ;$ b) $\mathrm{Li}_{[}\left[\mathrm{Et}_{3} \mathrm{BH}\right] / \mathrm{Et}_{2} \mathrm{O}$.

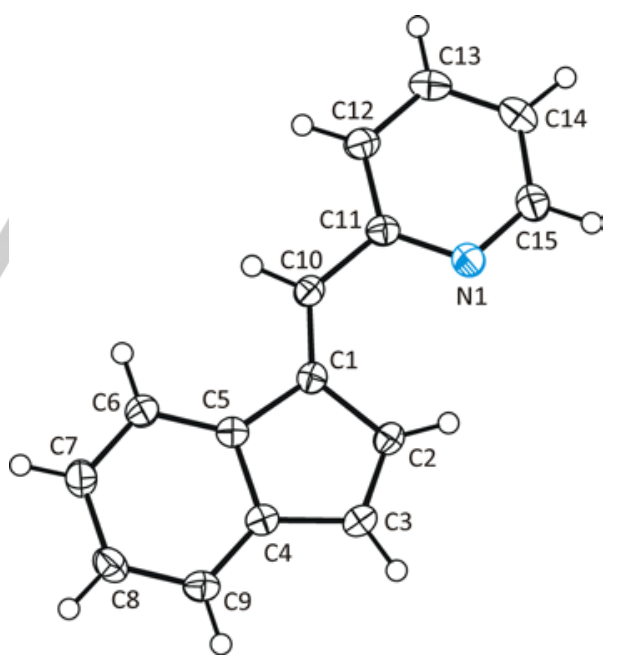

Figure 1. ORTEP drawing of benzofulvene 4'. The labeling scheme for all non-hydrogen atoms is shown. Thermal ellipsoids are drawn at the $50 \%$ probability level.

Infrared spectrum of the cyclopentadienyl molybdenum compound 7 shows two CO stretching bands at 1927 and 1838 $\mathrm{cm}^{-1}$. Higher wavenumbers observed for indenyl derivatives 8 and $9\left(\sim 1933\right.$ and $\left.\sim 1854 \mathrm{~cm}^{-1}\right)$ reflect lower electron density on central metals that is caused by weaker donor properties of the indenyl ligand. Raman spectrum, measured for $\mathbf{9}$, verifies the assignment of the band at lower frequency to symmetric vibration mode $\left(v_{s}\right)$ as evident from considerably higher 
intensity. ${ }^{1} \mathrm{H}$ NMR spectra of the compounds $7-9$ reveals presence of two conformers arising from two distinct orientations of the allyl ligand. This behavior is in line with counterparts bearing unsubstituted cyclopentadienyl and indenyl ligands. ${ }^{[15]}$ Deuterium substituted indene 4-D was used for synthesis of molybdenum compound selectively labeled in the position 3 of the indenyl ligand 8-[D]. High efficiency of the labeling (65\%) is due to lower acidity of deuterium at the $s p^{3}$ carbon atom of 4-D when compared corresponding proton.

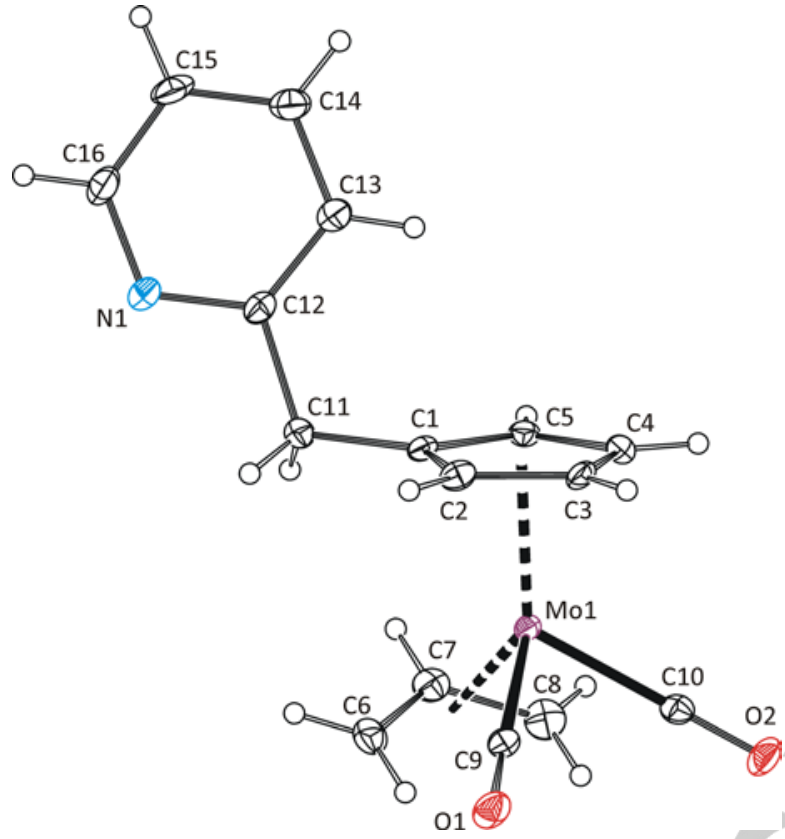

Figure 2. ORTEP drawing of molecule $\left[\left(\eta^{3}-\mathrm{C}_{3} \mathrm{H}_{5}\right)\left(\eta^{5}\right.\right.$ $\left.\mathrm{C}_{5} \mathrm{H}_{4} \mathrm{NCH}_{2} \mathrm{C}_{5} \mathrm{H}_{4}\right) \mathrm{Mo}(\mathrm{CO})_{2}$ ] present in crystal structure of 7 . The labeling scheme for all non-hydrogen atoms is shown. Thermal ellipsoids are drawn at the $30 \%$ probability level. Only one of two crystallographically independent molecules is shown for clarity.

Table 1. Geometric parameters of the tetracoordinated molydbenum complexes. ${ }^{[a]}$

\begin{tabular}{llll}
\hline & $7^{[b]}$ & $7^{[b]}$ & 9 \\
\hline $\mathrm{Mo}-\mathrm{Cg}\left(\mathrm{C}_{5}\right)$ & $2.014(3)$ & $2.022(3)$ & $2.027(2)$ \\
$\mathrm{Mo}-\mathrm{Cg}\left(\mathrm{C}_{3}\right)$ & $2.043(6)$ & $2.053(3)$ & $2.048(3)$ \\
$\mathrm{Mo}-\mathrm{C}(\mathrm{CO})$ & $1.966(6)$ & $1.948(6)$ & $1.938(3)$ \\
& $1.941(4)$ & $1.936(4)$ & $1.936(3)$ \\
$\mathrm{C}(\mathrm{CO})-\mathrm{Mo}-\mathrm{C}(\mathrm{CO})$ & $78.7(2)$ & $79.4(2)$ & $80.0(2)$ \\
$\mathrm{Cg}\left(\mathrm{C}_{5}\right)-\mathrm{Mo}-$ & $127.0(4)$ & $127.2(2)$ & $126.9(1)$ \\
$\mathrm{Cg}\left(\mathrm{C}_{3}\right)$ & & & \\
\hline
\end{tabular}

[a] Distances are given in $\AA$; angles are given in ${ }^{\circ}$. [b] Two crystallographically independent molecules in the unit cell.

Structures of molybdenum compounds $\mathbf{7}$ and $\mathbf{9}$ were determined by X-ray diffraction analysis. The molecules have a distorted tetrahedral structure with two carbonyl ligand, $\eta^{3}$-allyl and $\eta^{5}$ coodrinated $\pi$-ligand around molybdenum in the formal oxidation state II. Pyridine arms are not coordinated that obeys the 18electron rule. ${ }^{[16]}$

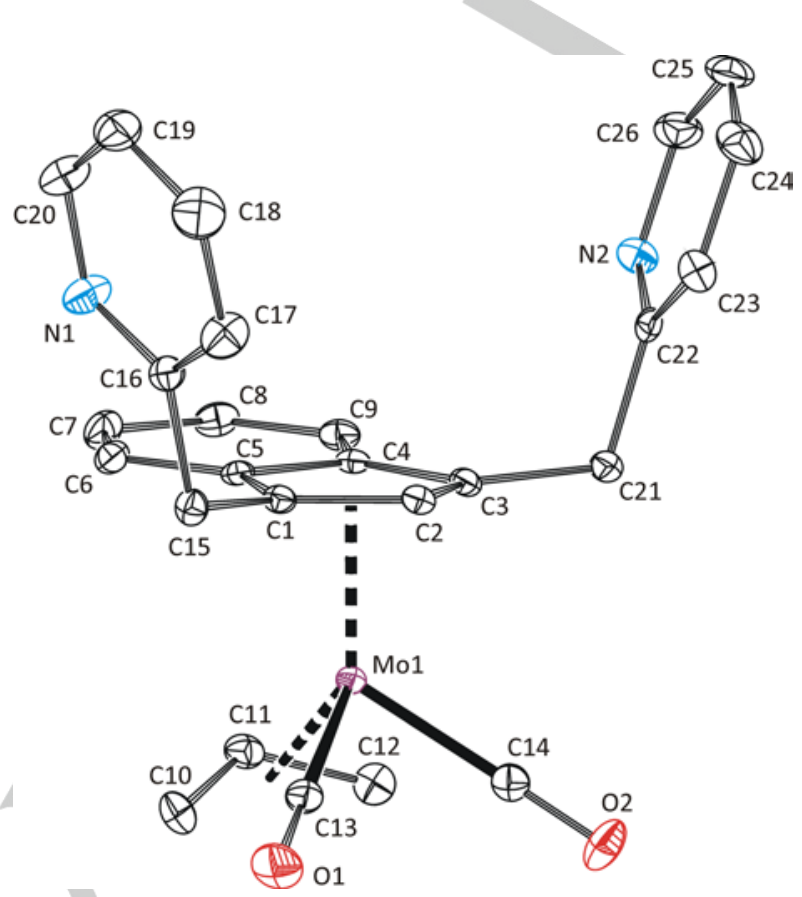

Figure 3. ORTEP drawing of molecule $\left[\left(\eta^{3}-\mathrm{C}_{3} \mathrm{H}_{5}\right)\left\{\eta^{5}-1,3\right.\right.$ $\left.\left(\mathrm{C}_{5} \mathrm{H}_{4} \mathrm{NCH}_{2}\right)_{2} \mathrm{C}_{9} \mathrm{H}_{5}\right\} \mathrm{Mo}(\mathrm{CO})_{2}$ ] present in crystal structure of 9. The labeling scheme for all non-hydrogen atoms is shown. Thermal ellipsoids are drawn at the $30 \%$ probability level. Hydrogen atoms are omitted for clarity.

Cyclopentadienyl molybdenum compounds with intramolecular coordination

Reaction of cyclopentadienyl molybdenum compound 7 with $\mathrm{HBF}_{4} \cdot \mathrm{Et}_{2} \mathrm{O}$ in presence of acetonitrile gives dicationic complex 10 with protonated pyridine arm. In acetonitrile solution, this compound undergoes slow deprotonation that is accompanied by exchange of $\mathrm{MeCN}$ ligand with pyridine of the side chain, see Scheme 5. The appeared compound with intramolecularly bonded pyridine arm (11) is inert toward strong acids in presence of coordinating solvents (e.g. $\mathrm{HBF}_{4} \cdot \mathrm{Et}_{2} \mathrm{O} / \mathrm{MeCN}$ ) that demonstrates high stability of $\left(\eta^{5}: \mathrm{KN}-\mathrm{C}_{5} \mathrm{H}_{4} \mathrm{NCH}_{2} \mathrm{C}_{5} \mathrm{H}_{4}\right) \mathrm{Mo}$ moiety. Putative intermediate of the deprotonation reaction, $\left[\left(\eta^{5}-\right.\right.$ $\left.\left.\mathrm{C}_{5} \mathrm{H}_{4} \mathrm{NCH}_{2} \mathrm{C}_{5} \mathrm{H}_{4}\right) \mathrm{Mo}(\mathrm{CO})_{2}(\mathrm{NCMe})_{2}\right]\left[\mathrm{BF}_{4}\right]$, was not observed probably due to fast coordination of the pyridine arm that is driven by strong chelating effect.

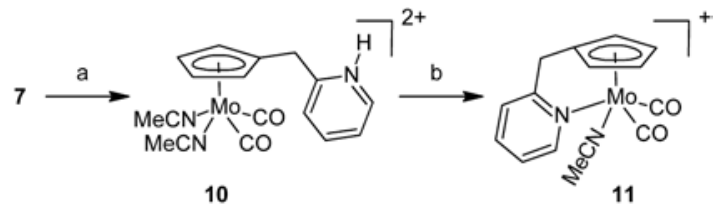

Scheme 5. Reactivity of cyclopentadienyl compound 7. Reagents: a) $\mathrm{HBF}_{4} \cdot \mathrm{Et}_{2} \mathrm{O}(2 \mathrm{eq}$. $\left.) / \mathrm{MeCN}, \mathrm{b}\right)$ acetone.

Infrared and Raman spectra of the compounds $\mathbf{1 0}$ and $\mathbf{1 1}$ show two CO stretching bands at higher wavelengths than observed 
for allyl precursor $\mathbf{7}$ that is in line with lower electron density on central metal. Intramolecular coordination of pyridine was easily recognized by ${ }^{1} \mathrm{H}$ NMR spectroscopy since the compound $\mathbf{1 0}$ is $C_{\mathrm{s}}$ symmetric while the species with coordinated pyridine arm $\mathbf{1 1}$ belongs to the point group $C_{1}$. This decrease of the molecular symmetry is distinct mainly on the pattern of signals assigned to methylene bridge and cyclopentadienyl ring. Hence, magnetically equivalent protons of $\mathrm{CH}_{2}$ group in $\mathbf{1 0}$ give one singlet at $4.10 \mathrm{ppm}$ while a quartet $\mathrm{AB}\left(\Delta \bar{\delta}_{\mathrm{AB}}=0.09 \mathrm{ppm},{ }^{2} \mathrm{~J}=\right.$ $19.8 \mathrm{~Hz}$ ) at $4.39 \mathrm{ppm}$ was observed for compound 11. Furthermore, the $C_{\mathrm{s}}$-symmetric species $\mathbf{1 0}$ gives two pseudotriplets (AA'BB' spin system) at 5.66 and 5.96 for four protons of cyclopentadienyl ring while lower symmetric compound $\mathbf{1 1}$ show four multiplets (ABCD spin system) at 5.19-6.65 ppm.

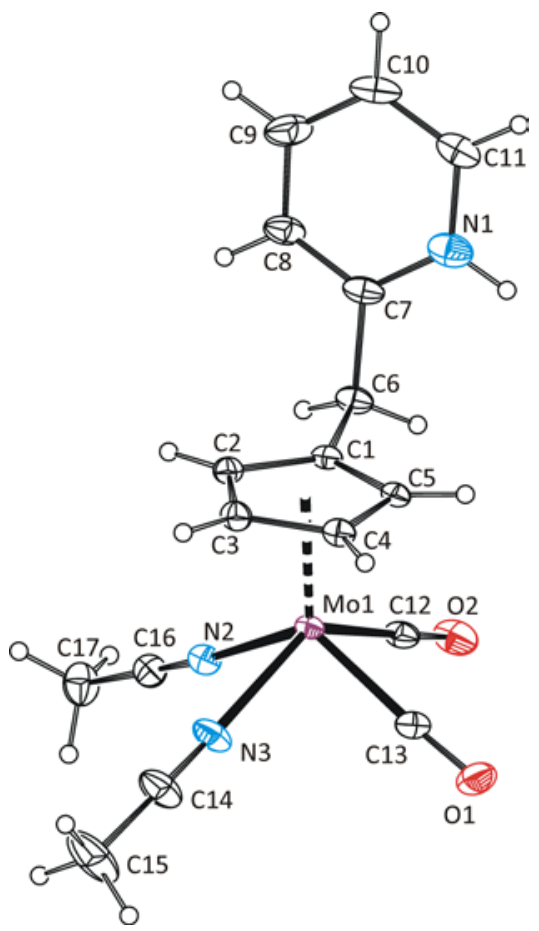

Figure 4. ORTEP drawing of dication $\left[\left(\eta^{5}-\right.\right.$ $\left.\left.\mathrm{C}_{5} \mathrm{H}_{4} \mathrm{NHCH}_{2} \mathrm{C}_{5} \mathrm{H}_{4}\right) \mathrm{Mo}(\mathrm{CO})_{2}(\mathrm{NCMe})_{2}\right]^{2+}$ present in crystal structure of 10 . The labeling scheme for all non-hydrogen atoms is shown. Thermal ellipsoids are drawn at the $30 \%$ probability level.

The crystal structures of the compounds 10 and $\mathbf{1 1}$ were determined by X-ray diffraction analysis (Figs 4 an 5). Both compounds have a distorted square-pyramidal structure with $\eta^{5}$ bonded cyclopentadienyl ligand in the apical position and two carbonyls in adjacent vertices of the basal plane. In 10, two acetonitrile ligands occupy the remaining vertices of the basal plane. In case of 11, these two positions are occupied with acetonitrile ligand and intramolecularly bonded pyridine.

Bond distance Mo-N [2.229(4)-2.238(4) A] is considerably shorter than reported for species bearing intramolecularly coordinated tertiary amine $\left[\left(\eta^{5}: \mathrm{KN}\right.\right.$ $\left.\left.\mathrm{Me}_{2} \mathrm{NCH}_{2} \mathrm{CH}_{2} \mathrm{C}_{5} \mathrm{H}_{4}\right) \mathrm{Mo}(\mathrm{CO})_{2} \mathrm{l}\right]\left[(2.380(3) \AA]^{[17]}\right.$ but comparable with more nucleophilic primary amine $\left[\left(\eta^{5}: K N\right.\right.$ $\left.\left.\mathrm{H}_{2} \mathrm{NCH}_{2} \mathrm{CH}_{2} \mathrm{C}_{5} \mathrm{H}_{4}\right) \mathrm{Mo}(\mathrm{CO})_{2}\left(\mathrm{PPh}_{3}\right)\right]\left[\mathrm{PF}_{6}\right][2.254(8) \AA] .{ }^{[18]}$

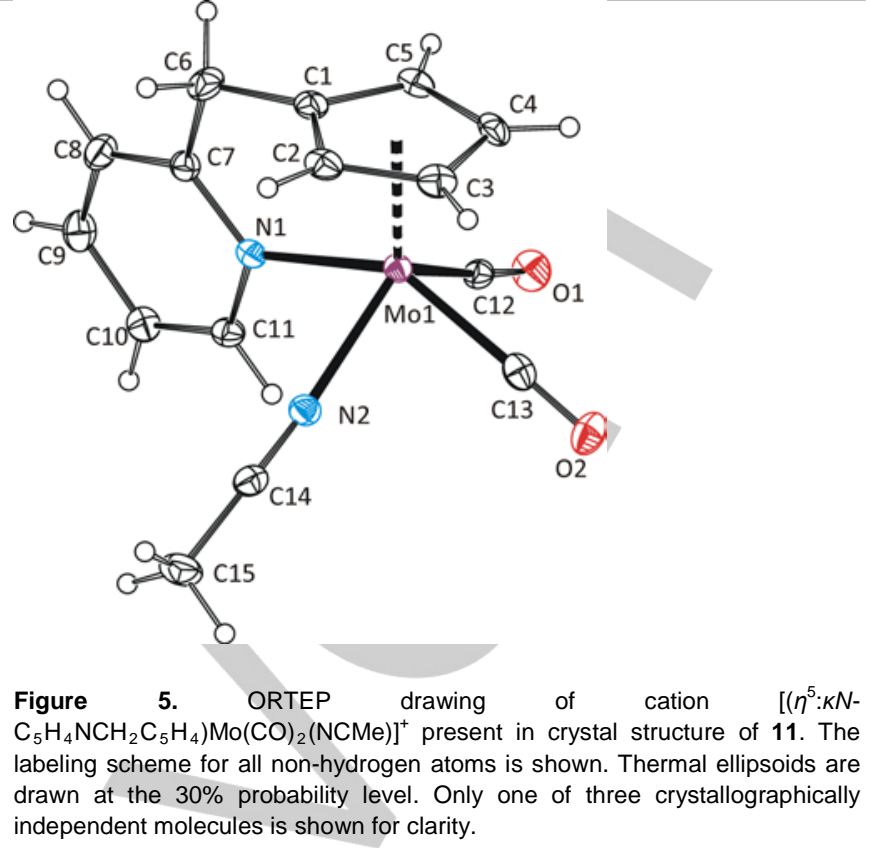
independent molecules is shown for clarity.

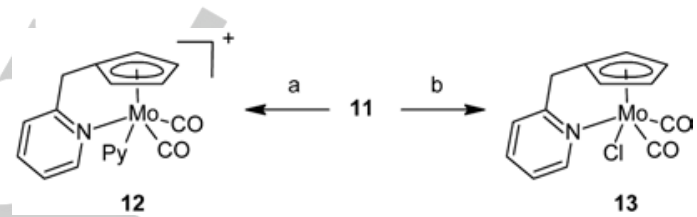

Scheme 6. Reactivity of cyclopentadienyl compound 11. Reagents: a) $\mathrm{Py} / \mathrm{CH}_{2} \mathrm{Cl}_{2}$, b) $\left[\mathrm{Me}_{4} \mathrm{~N}\right] \mathrm{Cl} /$ acetone.

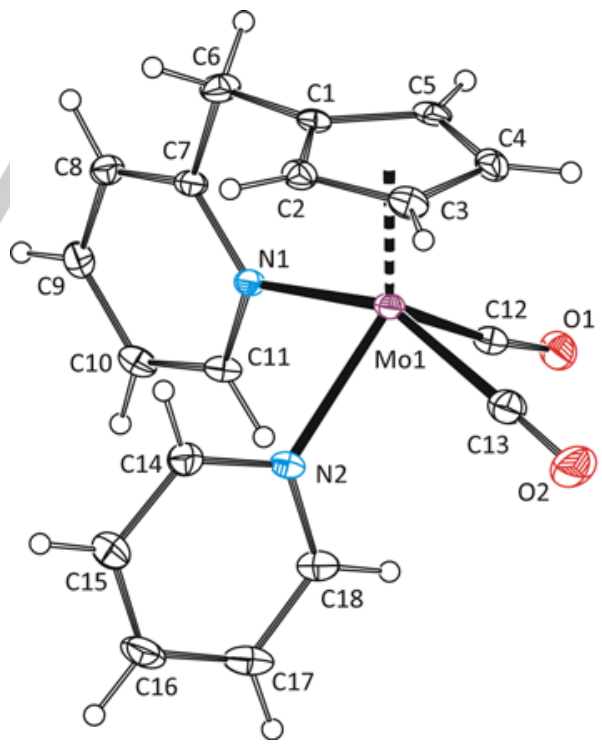

Figure 6. ORTEP drawing of cation $\left[\left(\eta^{5}: K N-\mathrm{C}_{5} \mathrm{H}_{4} \mathrm{NCH}_{2} \mathrm{C}_{5} \mathrm{H}_{4}\right) \mathrm{Mo}(\mathrm{CO})_{2}(\mathrm{py})\right]^{+}$ present in crystal structure of $\mathbf{1 2}$. The labeling scheme for all non-hydrogen atoms is shown. Thermal ellipsoids are drawn at the $30 \%$ probability level.

Acetonitrile ligand of the compound $\mathbf{1 1}$ could be easily exchanged by 2e-ligands such as pyridine of chloride, see Scheme 6. ${ }^{1} \mathrm{H}$ NMR spectra of the products 12 and 13 show a pattern consistent with $C_{1}$ molecular symmetry. Methylene 
groups of the intramolecular bridge give quartets $A B(12: \delta=$ $4.55 \mathrm{ppm}, \Delta \delta_{\mathrm{AB}}=0.30 \mathrm{ppm},{ }^{2} \mathrm{~J}=19.8 \mathrm{~Hz} ; 13: \delta=4.26 \mathrm{ppm}$, $\Delta \delta_{A B}=0.06 \mathrm{ppm},{ }^{2} \mathrm{~J}=19.8 \mathrm{~Hz}$ ) that is typical for rigid lowsymmetric compounds. Protons of cyclopentadienyl ring appear as four multiplets of the ABCD spin system.

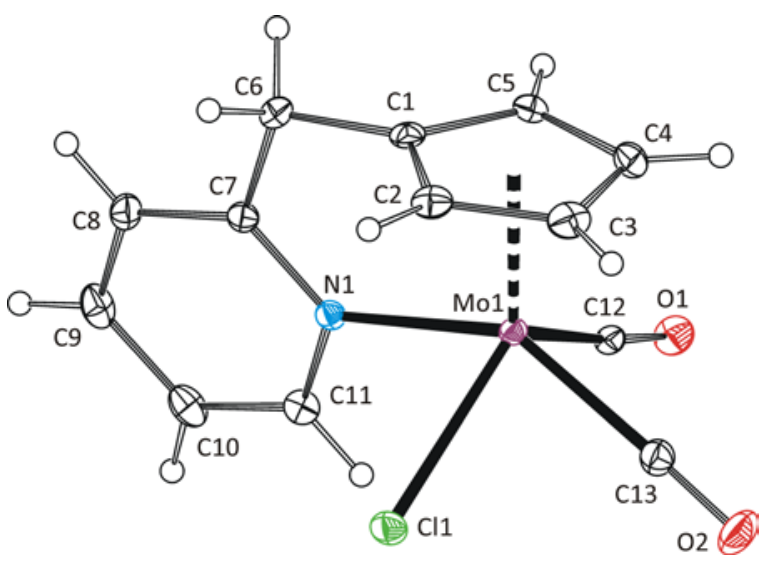

Figure 7. ORTEP drawing of molecule $\left[\left(\eta^{5}: \mathrm{KN}-\mathrm{C}_{5} \mathrm{H}_{4} \mathrm{NCH}_{2} \mathrm{C}_{5} \mathrm{H}_{4}\right) \mathrm{Mo}(\mathrm{CO})_{2} \mathrm{Cl}\right]$ present in crystal structure of $\mathbf{1 3}$. The labeling scheme for all non-hydrogen atoms is shown. Thermal ellipsoids are drawn at the $30 \%$ probability level.
Infrared and Raman spectra of the neutral chloride complex $\mathbf{1 3}$ show the $\mathrm{CO}$ stretching bands at considerably lower wavenumbers than cationic analogues bearing acetonitrile (11) or pyridine ligand (12). It is due to higher electron density on metal that enhances back donation into $\pi^{*}$-orbitals of carbonyl ligands.

Structures of 12 and 13, elucidated by analytical and spectroscopic measurements, were further verified by X-ray diffraction analysis (Figs. 6 and 7). In case of 12, the bond distance between molybdenum atom and nitrogen of the pyridine ligand $[\mathrm{Mo}-\mathrm{N} 2=2.230(3) \AA]$ is very similar to intramolecularly coordinated pyridine arm [Mo-N2 = 2.256(3) $\AA$ ]. Evidently, the chelate effect on the bond distance Mo-N1 is here compensated with weaker trans effect of the carbonyl ligands $\left[\mathrm{N} 1-\mathrm{Mo}-\mathrm{C} 13=150.1(2)^{\circ}, \mathrm{N} 2-\mathrm{Mo}-\mathrm{C} 12=104.9(2)^{\circ}\right]$.

The compounds $\mathbf{1 2}$ and $\mathbf{1 3}$ are inert toward excess of pyridine and $\left[\mathrm{Me}_{4} \mathrm{~N}\right] \mathrm{Cl}$, respectively. It suggests considerably stronger intramolecular interaction than recently reported for analogues with tertiary amines connected to cyclopentadienyl ring via ethylene bridge. ${ }^{[19]}$ Due to $\pi$-basicity of pyridine, the $\left(\eta^{5}: \mathrm{KN}\right.$ $\left.\mathrm{C}_{5} \mathrm{H}_{4} \mathrm{NCH}_{2} \mathrm{C}_{5} \mathrm{H}_{4}\right) \mathrm{Mo}^{\prime \prime}$ moiety of $\mathbf{1 1}$ is not disrupted even by strong $\mathrm{N}, \mathrm{N}$-chelators (e.g. bpy, phen). We note that tertiary amine-functionalized analogues give under similar conditions solely species without intramolecular interaction $\left[\left(\eta^{5}\right.\right.$ $\left.\mathrm{R}_{2} \mathrm{NCH}_{2} \mathrm{CH}_{2} \mathrm{C}_{5} \mathrm{H}_{4}\right) \mathrm{Mo}(\mathrm{CO})_{2}$ (phen)][BF $]_{4}^{[19]}$

Table 2. Geometric parameters of the pentacoordinated molydbenum complexes. ${ }^{[a]}$

\begin{tabular}{|c|c|c|c|c|c|c|}
\hline & 10 & $11^{[\mathrm{b}]}$ & $11^{[\mathrm{b}]}$ & $11^{[\mathrm{b}]}$ & 12 & 13 \\
\hline $\mathrm{Mo}-\mathrm{Cg}\left(\mathrm{C}_{5}\right)$ & $1.980(1)$ & $1.964(1)$ & $1.968(2)$ & $1.961(1)$ & $1.985(3)$ & $1.9767(3)$ \\
\hline \multirow[t]{2}{*}{ Mo-C(CO) } & $1.981(4)$ & $1.999(4)$ & $2.017(4)$ & $2.009(4)$ & $2.028(4)$ & $1.942(2)$ \\
\hline & $1.966(3)$ & $1.942(4)$ & $1.954(4)$ & $1.947(4)$ & $1.928(4)$ & $1.993(2)$ \\
\hline Mo-N1 & - & $2.229(4)$ & $2.238(4)$ & $2.234(4)$ & $2.256(3)$ & $2.237(2)$ \\
\hline \multirow[t]{2}{*}{ Mo- $-X^{[c]}$} & $2.165(3)$ & $2.156(3)$ & $2.150(3)$ & 2.15 & $2.230(3)$ & $2.4910(4)$ \\
\hline & $2.167(3)$ & & & & & \\
\hline $\mathrm{C}(\mathrm{CO})-\mathrm{Mo}-\mathrm{C}(\mathrm{CO})$ & $74.6(2)$ & $76.3(2)$ & $77.7(2)$ & $75.8(2)$ & $78.8(2)$ & $77.3(1)$ \\
\hline $\mathrm{X}-\mathrm{Mo}-\mathrm{N}^{[\mathrm{c}]}$ & $78.4(2)$ & $77.9(2)$ & $78.0(2)$ & $79.0(2)$ & $78.8(1)$ & $78.85(4)$ \\
\hline$\alpha^{[d]}$ & - & $0.3(3)$ & $3.0(3)$ & $0.2(3)$ & $1.1(3)$ & $8.3(2)$ \\
\hline$\beta^{[\mathrm{e}]}$ & - & $10.2(5)$ & $1.3(5)$ & $8.6(5)$ & $1.2(4)$ & $0.8(2)$ \\
\hline
\end{tabular}

[a] Distances are given in $\AA$; angles are given in ${ }^{\circ}$. [b] Three crystallographically independent molecules in the unit cell. [c] 10: $X=N 2, N 311,12: X=N 2 ; 13: X=C l 1$. [d] a represents orientation of the pyridine toward axis defined by $\mathrm{Mo}-\mathrm{Cg}(\mathrm{C} 5)$. It is defined as absolute value of dihedral angle $\mathrm{Cg}(\mathrm{C} 5)-\mathrm{Mo1}-\mathrm{N} 1-\mathrm{C} 7$. [e] $\beta$ represents twisting of the coordinated arm. It is defined as absolute value of dihedral angle $\mathrm{C} 1-\mathrm{C} 6-$ C7-N1.

Indenyl molybdenum compounds with intramolecular coordination

Reaction of indenyl molybdenum compound 8 with $\mathrm{HBF}_{4} \cdot \mathrm{Et}_{2} \mathrm{O}$ in presence of acetonitrile leads, similarly as in case of cyclopentadienyl analogue 7 , to exchange of $\eta^{3}$-allyl ligand with acetonitrile ligands. Surprisingly, the standard work up does not give expected pentacoordinated species with $\eta^{5}$-bonded indenyl but solely hexacoordinated $\eta^{3}$-indenyl complex with intramolecularly coordinated pyridine arm 14, see Scheme 7 .
The infrared spectrum shows two bands in range typical for terminal carbonyl ligands. The hapticity of indenyl ligand was elucidated from ${ }^{1} \mathrm{H}$ NMR measurements. Since the compound 14 gives one set of sharp signals at room, consistent with $C_{1}$ molecular symmetry, fluxional behavior is not expected in solution. According to previous studies on indenyl compounds without substituents in five-membered ring, ${ }^{[10,12,13]}$ the chemical shifts of $\mathrm{H}^{1 / 3}$ and $\mathrm{H}^{2}$ are diagnostic for hapticity elucidation Hence, in case of the organometallic compounds bearing $\eta^{3}$ - 
indenyl ligand, the signal of $\mathrm{H}^{2}$ appears at considerably lower field than $\mathrm{H}^{1 / 3}$ while $\eta^{5}$-species have the signal of $\mathrm{H}^{2}$ at higher field. This relation is, of course, applicable on our species bearing a substituent in position 1 but only after unambiguous assignment of two doublets $\left({ }^{2} \mathrm{~J}=3.9 \mathrm{~Hz}\right)$ to $\mathrm{H}^{2}$ and $\mathrm{H}^{3}$. It led as to use deuterium labeled derivative 8-[D] for synthesis of 14-[D] (Scheme 7). The labeling results in considerable decrease of the doublet at $5.14 \mathrm{ppm}\left(\mathrm{H}^{3}\right)$ in intensity and in broadening of signal at $6.83 \mathrm{ppm}\left(\mathrm{H}^{2}\right)$ due to spin-spin interactions $\mathrm{H}^{2}-[\mathrm{D}]^{3}$. This experiment unambiguously revealed $\eta^{3}$-coordination mode of the indenyl ligand that was confirmed in solid state by $\mathrm{X}$-ray diffraction analysis (Fig. 8).

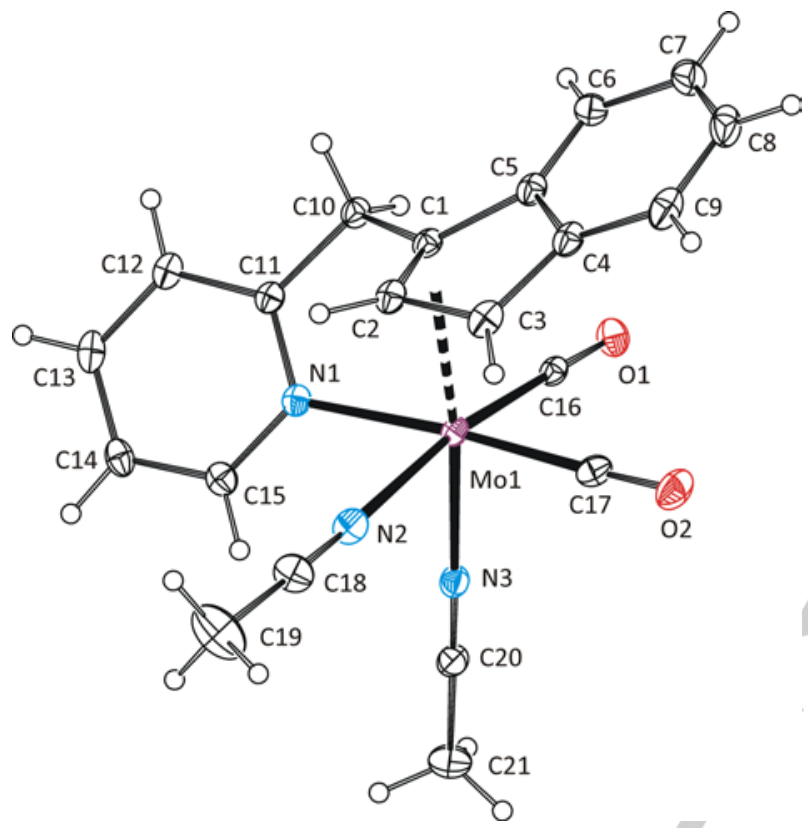

Figure 8. ORTEP drawing of cation $\left[\left\{\eta^{3}: K N-1\right.\right.$ $\left.\left.\left(\mathrm{C}_{5} \mathrm{H}_{4} \mathrm{NCH}_{2}\right) \mathrm{C}_{9} \mathrm{H}_{6}\right\} \mathrm{Mo}(\mathrm{CO})_{2}(\mathrm{NCMe})_{2}\right]^{+}$present in crystal structure of 14. $\mathrm{CH}_{2} \mathrm{Cl}_{2}$. The labeling scheme for all non-hydrogen atoms is shown. Thermal ellipsoids are drawn at the $30 \%$ probability level.

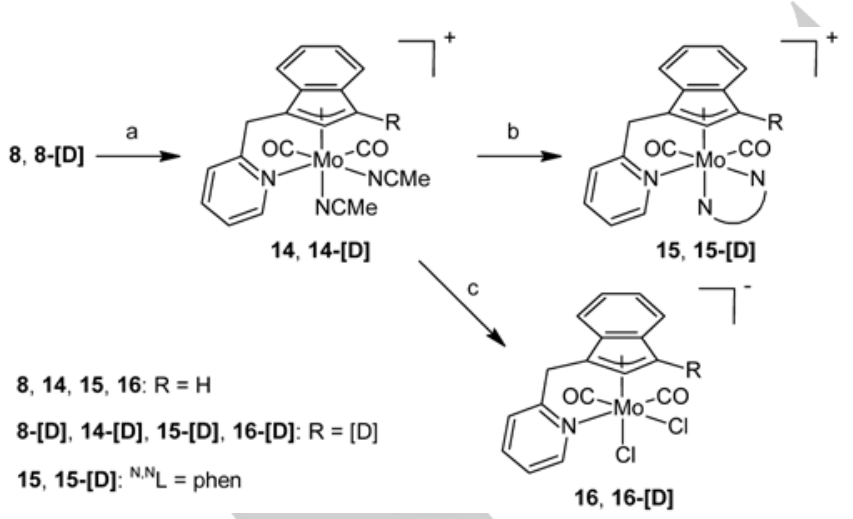

Scheme 7. Reactivity of indenyl compounds 8 and 8-[D]. Reagents: a) $\mathrm{HBF}_{4} \cdot \mathrm{Et}_{2} \mathrm{O}$ (1 eq.), $\mathrm{MeCN}$ (2 eq.)/CH $\mathrm{CH}_{2} \mathrm{Cl}_{2}, \quad$ b) phen/MeCN, c) $\left[\mathrm{Me}_{4} \mathrm{~N}\right] \mathrm{Cl} /$ acetone.

Exchange of acetonitrile ligands does not disrupt coordination of the pyridine arm as demonstrated on reactions with 1,10phenanthroline and $\left[\mathrm{Me}_{4} \mathrm{~N}\right] \mathrm{Cl}$, see Scheme 7 . In both cases, only products of simple ligand exchange were isolated. The retention of indenyl ligand hapticity in the species 15 and $\mathbf{1 6}$ was confirmed by deuterium labeling study. Similarly as observed for compound 14, the signal the indenyl proton $\mathrm{H}^{2}$ appears in ${ }^{1} \mathrm{H}$ NMR spectra at considerably lower filed that signal of $\mathrm{H}^{3}$.

Although the appearance of dichloride $\mathbf{1 6}$ seems to be obvious, it is rather unusual. From mechanistic point of view, one may expect formation of pentacoordinated species with coordination sphere resembling the recently described chloride complex [ $\left(\eta^{5}-\right.$ $\left.\left.4,7-\mathrm{Me}_{2} \mathrm{C}_{9} \mathrm{H}_{5}\right) \mathrm{Mo}(\mathrm{CO})_{2}(\mathrm{py}) \mathrm{Cl}\right] .{ }^{[12]}$ The unusual stability of the compound $\mathbf{1 6}$ is probably not only a result of constrained geometry but also due to high energetic barrier of the $\eta^{3}: \eta^{5}$ indenyl ring slippage as will be discussed in detail later on compound 14

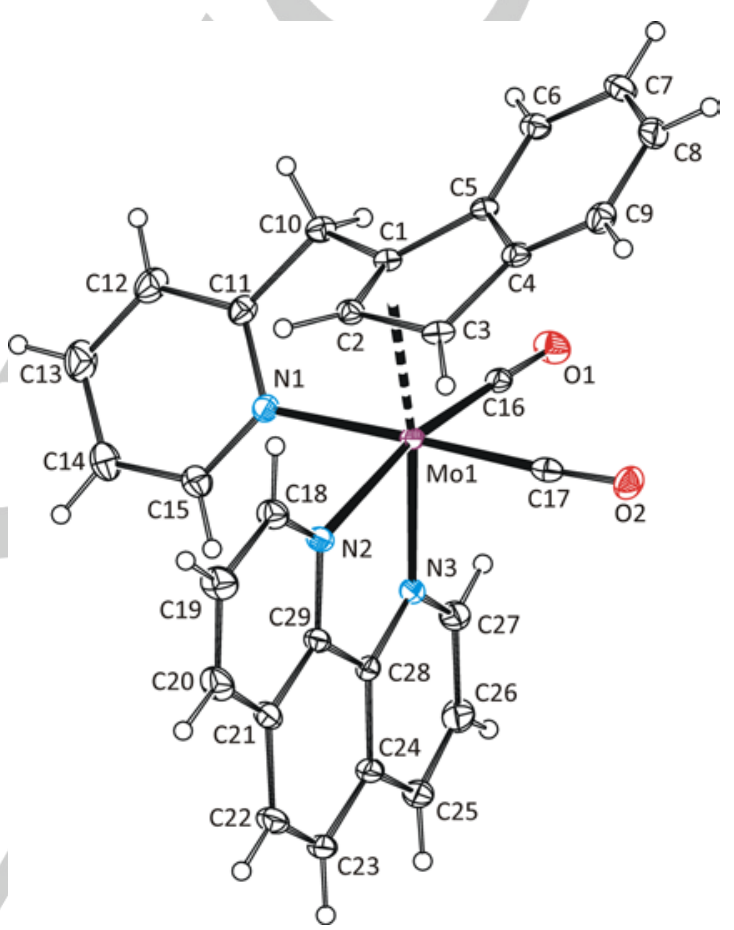

Figure 9. ORTEP drawing of cation $\left[\left\{\eta^{3}: K N-1\right.\right.$ $\left.\left(\mathrm{C}_{5} \mathrm{H}_{4} \mathrm{NCH}_{2}\right) \mathrm{C}_{9} \mathrm{H}_{6}\right\} \mathrm{Mo}(\mathrm{CO})_{2}$ (phen) $]^{+}$present in crystal structure of 15 . The labeling scheme for all non-hydrogen atoms is shown. Thermal ellipsoids are drawn at the $30 \%$ probability level.

Crystal structures of 14,15 and $16 \cdot{ }^{1} / \mathrm{Me}_{2} \mathrm{CO}$ were determined by X-ray diffraction analysis (Figures 8-10). The molecules have a distorted octahedral structure with one face occupied by centroid of the indenyl ligand and two carbonyl ligands. The opposite octahedral face is occupied by nitrogen atom of pyridine arm and two donor atoms of remaining ligands. Due to short intramolecular bridge, the pyridine arm and indenyl are in cis-configuration. High values of envelop fold angle $[\Omega=$ 25.0(5)-26.3(6) $\left.{ }^{\circ}\right]$ and $\Delta(\mathrm{M}-\mathrm{C})[0.830(5)-0.871(4) \AA]$, observed for indenyl ligand, verifies the $\eta^{3}$-coordination mode. The indenyl ligand takes configuration with $\mathrm{C}_{6}$-ring above carbonyls that is common for the hexacoordinated molybdenum compounds without intramolecular coordination. $\left.{ }^{[12,} 13,20\right]$ The $\eta^{3}: \mathrm{KN}$ coordination mode of the $s$ functionalized indenyl ligand is unprecedented. Hence, the more conventional $\eta^{5}: K N$ was reported for number of lanthanide ${ }^{[21]}$ and group IV metal 
compounds. ${ }^{[22]}$ The species of intermediate hapticity between $\eta^{5}$ and $\eta^{2: 1}$ was described on nickel complex $\left[\left\{\eta^{5 \leftrightarrow 2: 1}: K N-1-\right.\right.$ $\left.\left.\left(\mathrm{C}_{5} \mathrm{H}_{4} \mathrm{NCH}_{2}\right) \mathrm{C}_{9} \mathrm{H}_{6}\right\} \mathrm{Ni}\left(\mathrm{PPh}_{3}\right)\right]\left[\mathrm{BPh}_{4}\right]$. This species has shown considerably lower values of $\Omega\left[11.48(14)^{\circ}\right]$ and $\Delta(\mathrm{M}-\mathrm{C})$ $[0.242(3) \AA]$ than observed for $\eta^{3}: k N$-molybdenum complexes reported here; see Table $3 .^{[23]}$ In contrast to cyclopentadienyl compounds 11-13, the indenyl complexes do not have the plane of pyridine ring parallel to the axis $\mathrm{Cg}-\mathrm{Mo}$ and the arm is twisted as evident from considerably higher values of the parameters $\alpha$ $\left[34.2(3)-38.0(3)^{\circ}\right]$ and $\beta\left[19.6(6)-31.2(5)^{\circ}\right]$, respectively (cf. with data in Table 2). Furthermore, the intramolecular bond Mo-N1 is considerably longer than observed for cyclopentadienyl species 11-13. The prolongation, observed for indenyl compounds, is due to more efficient trans effect of the carbonyl ligands. This phenomenon also clarifies the systematically longer bonds Mo$\mathrm{X}_{\text {eq }}$ when compared to Mo- $\mathrm{X}_{\mathrm{ax}}$, see Table 3.

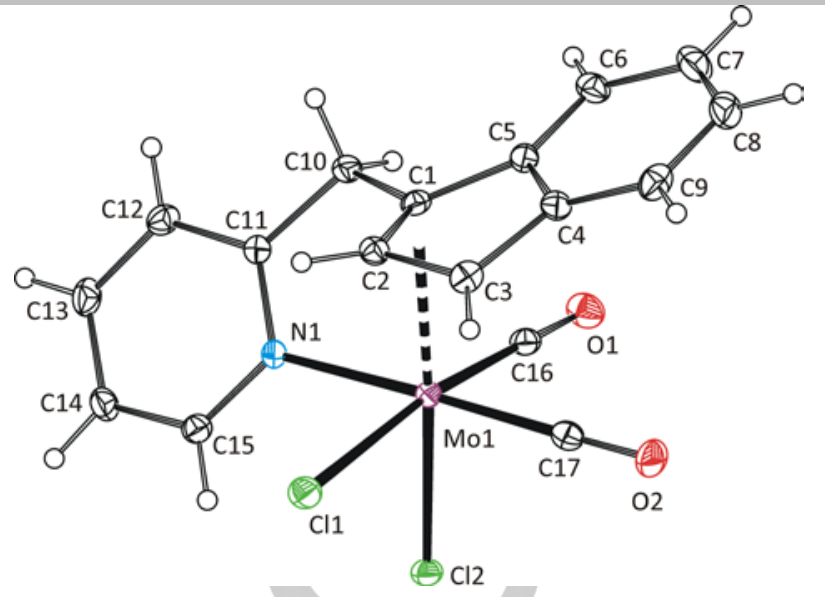

Figure 10. ORTEP drawing of anion $\left[\left\{\eta^{3}: K N-1-\right.\right.$ $\left.\left.\left(\mathrm{C}_{5} \mathrm{H}_{4} \mathrm{NCH}_{2}\right) \mathrm{C}_{9} \mathrm{H}_{6}\right\} \mathrm{Mo}(\mathrm{CO})_{2} \mathrm{Cl}_{2}\right]^{-}$present in crystal structure of $16 \cdot{ }^{1} /{ }_{2} \mathrm{Me}_{2} \mathrm{CO}$ The labeling scheme for all non-hydrogen atoms is shown. Thermal ellipsoids are drawn at the $30 \%$ probability level. Only one of two crystallographically independent molecules is shown for clarity.

Table 3. Geometric parameters of the hexacoordinated molybdenum complexes. ${ }^{[a]}$

\begin{tabular}{|c|c|c|c|c|c|}
\hline & 14. $\mathrm{CH}_{2} \mathrm{Cl}_{2}$ & 15 & $16 \cdot{ }^{1} / 2 \mathrm{Me}_{2} \mathrm{CO}^{[\mathrm{b}]}$ & $16 \cdot 1 / 2 \mathrm{Me}_{2} \mathrm{CO}^{[\mathrm{b}]}$ & 18 \\
\hline $\mathrm{Mo}-\mathrm{Cg}\left(\mathrm{C}_{3}\right)$ & $2.069(4)$ & $2.063(4)$ & $2.078(4)$ & $2.043(5)$ & $2.051(1)$ \\
\hline \multirow[t]{2}{*}{ Mo-C(CO) } & $2.002(4)$ & $1.978(4)$ & $1.960(5)$ & $1.947(6)$ & $1.979(2)$ \\
\hline & $1.966(4)$ & $1.957(4)$ & $1.934(5)$ & $1.932(6)$ & $1.963(2)$ \\
\hline Mo-N1 & $2.270(3)$ & $2.274(3)$ & $2.282(4)$ & $2.268(4)$ & $2.284(2)$ \\
\hline Mo- $X_{\text {eq }}{ }^{[c]}$ & $2.222(4)$ & $2.259(3)$ & $2.568(2)$ & $2.544(2)$ & $2.302(2)$ \\
\hline Mo- $\mathrm{X}_{\mathrm{ax}}{ }^{[\mathrm{d}]}$ & $2.162(4)$ & $2.200(4)$ & $2.517(2)$ & $2.506(2)$ & $2.167(2)$ \\
\hline $\mathrm{X}_{\mathrm{ax}}-\mathrm{Mo}-\mathrm{Cg}\left(\mathrm{C}_{3}\right)^{[\mathrm{d}]}$ & $172.9(2)$ & $171.6(2)$ & $175.2(2)$ & $176.6(2)$ & $171.7(1)$ \\
\hline $\mathrm{C}(\mathrm{CO})-\mathrm{Mo}-\mathrm{C}(\mathrm{CO})$ & $82.6(2)$ & $82.0(2)$ & $81.6(2)$ & $82.3(2)$ & $80.6(1)$ \\
\hline $\mathrm{N} 1-\mathrm{Mo}-\mathrm{X}_{\mathrm{eq}}{ }^{[\mathrm{c}]}$ & $83.7(2)$ & $88.0(2)$ & $87.0(1)$ & $86.1(1)$ & $95.2(1)$ \\
\hline$\Omega^{[\mathrm{e}]}$ & $25.5(5)$ & $26.3(4)$ & $25.0(5)$ & $26.3(6)$ & $26.9(3)$ \\
\hline$\Delta(\mathrm{M}-\mathrm{C})^{[\mathrm{f}]}$ & $0.842(4)$ & $0.871(4)$ & $0.830(5)$ & $0.849(6)$ & $0.842(3)$ \\
\hline$\alpha^{[g]}$ & $34.2(3)$ & $35.0(3)$ & $35.3(3)$ & $38.0(3)$ & $40.2(2)^{[i]}$ \\
\hline$\beta^{[h]}$ & $31.2(5)$ & $26.3(5)$ & $26.6(5)$ & $19.6(6)$ & $23.8(3)^{[i]}$ \\
\hline
\end{tabular}

[a] Distances are given in $\AA$; angles are given in ${ }^{\circ}$. [b] Two crystallographically independent molecules in the unit cell. [c] 14. $\mathrm{CH}_{2} \mathrm{Cl}_{2}, 15,17: \mathrm{X}_{\text {eq }}=\mathrm{N} 2 ; 16 \cdot{ }^{1} /{ }_{2} \mathrm{Me}_{2} \mathrm{CO}: \mathrm{X}_{\text {eq }}=\mathrm{Cl}$. [d] 14. $\mathrm{CH}_{2} \mathrm{Cl}_{2}, 15,17: \mathrm{X}_{\mathrm{ax}}=\mathrm{N} 3 ; 16 \cdot{ }^{1} /{ }_{2} \mathrm{Me}_{2} \mathrm{CO}$ : $\mathrm{X}_{\mathrm{ax}}=\mathrm{Cl} 2$. [e] $\Omega$ is the envelope fold angle defined as the angle between planes defined by $\mathrm{C} 1, \mathrm{C} 2$ and $\mathrm{C} 3$ and that of $\mathrm{C} 1, \mathrm{C} 3, \mathrm{C} 4$ and $\mathrm{C}_{5}{ }^{[24]}[\mathrm{f}] \Delta(\mathrm{M}-\mathrm{C})$ represents the differences in the metal-carbon bonds. It is defined as the difference between the averages of the metal-carbon distances Mo-C4 and Mo-C5 and those of Mo-C1, Mo-C2 and $\mathrm{M}-\mathrm{C} 3{ }^{[24]}[\mathrm{g}] \alpha$ is defined as absolute value of dihedral angle $\mathrm{Cg}(\mathrm{C} 3)-\mathrm{Mo1}-\mathrm{N} 1-\mathrm{C} 11$; $[\mathrm{h}] \beta$ is defined as absolute value of dihedral angle C1-C10-C11-N1. [i] The values for the second coordinated arm are $\alpha=35.3(2)^{\circ}$; $\beta=25.5(3)^{\circ}$.

Indenyl complex bearing two pyridine arms 9 reacts with $\mathrm{HBF}_{4} \cdot \mathrm{Et}_{2} \mathrm{O}$ to give dicationic species 17 , see Scheme 8 . In this compound, one pyridine arm is protonated while the second one is intramolecularly coordinated to the central metal. The indenyl ring is $\eta^{3}$-bonded as evident from low-fielded signal of $\mathrm{H}^{2}(\delta=$ $7.18 \mathrm{ppm})$. The methylene group of the uncoordinated arm gives quartets $A B$ with very low value of the $\Delta \delta_{A B}(0.04 \mathrm{ppm})$. Considerably higher separation appears in the coordinated arm 
$\left(\Delta \delta_{\mathrm{AB}}=0.28 \mathrm{ppm}\right)$ that is in line with observations on structurally related complexes 14-16. The pyridinium ring in side arm of 17 could be deprotonated by excess of pyridine. This process is accompanied with exchange of the MeCN ligand (in cis-position to indenyl) with pyridine of the side chain to gives novel scorpionate-like compound $\mathbf{1 8}$ with two irreversibly coordinated arms on indenyl core. Due to steric hindrance, the $\mathrm{MeCN}$ ligand (in trans-position to indenyl) is not exchanged by pyridine. Nevertheless, it could be exchanged by less demanding chloride ligand to give compound $\mathbf{1 9}$, see Scheme 9 .

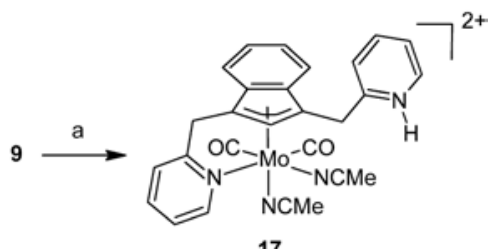

Scheme 8. Reactivity of indenyl compound 9. Reagents: a) $\mathrm{HBF}_{4} \cdot \mathrm{Et}_{2} \mathrm{O}$ (3 eq.) $/ \mathrm{MeCN}$.

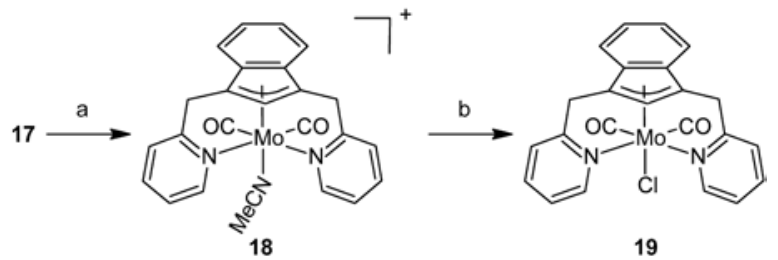

Scheme 9. Reactivity of indenyl compound 17. Reagents: a) py b) $\left[\mathrm{Me}_{4} \mathrm{~N}\right] \mathrm{Cl} /$ acetone.

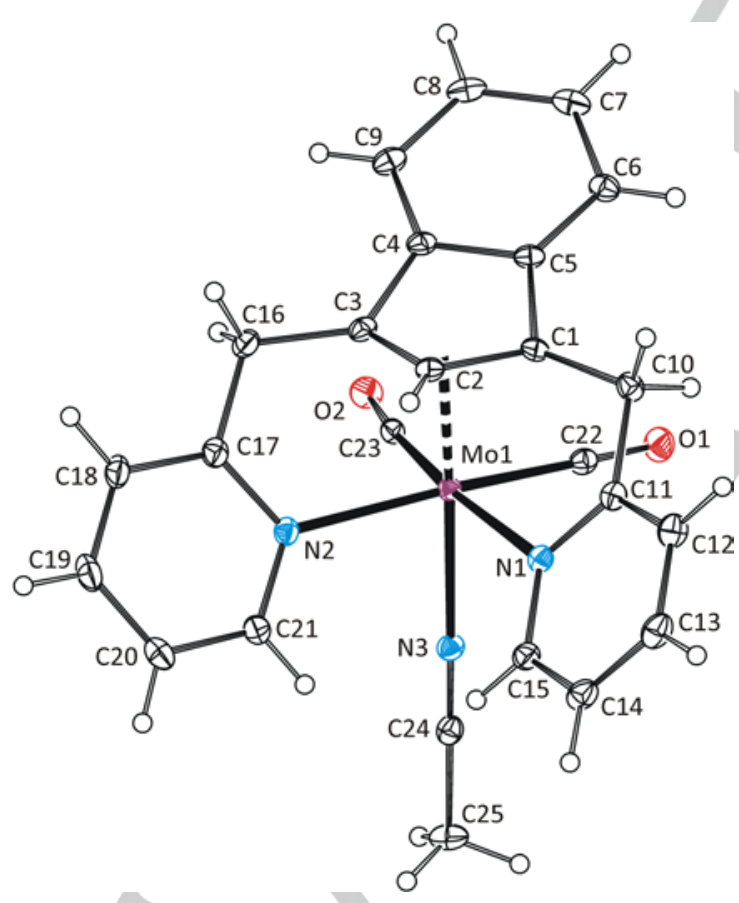

Figure 11. ORTEP drawing of cation $\left[\left\{\eta^{3}: k N, N-1,3\right.\right.$ $\left.\left.\left(\mathrm{C}_{5} \mathrm{H}_{4} \mathrm{NCH}_{2}\right)_{2} \mathrm{C}_{9} \mathrm{H}_{5}\right\} \mathrm{Mo}(\mathrm{CO})_{2}(\mathrm{NCMe})\right]^{+}$present in crystal structure of 18 . The labeling scheme for all non-hydrogen atoms is shown. Thermal ellipsoids are drawn at the $30 \%$ probability level.
The compounds with two intramolecularly bonded pyridine arms (18 and 19) are $C_{s}$ symmetric as evident from pattern of the ${ }^{1} \mathrm{H}$ NMR spectra. In both cases, methylene groups give one quartet $\mathrm{AB}$ with ${ }^{2} \mathrm{~J} \sim 19.5 \mathrm{~Hz}\left(\right.$ 18: $\Delta \bar{\delta}_{\mathrm{AB}}=0.27 \mathrm{ppm}$, 19: $\Delta \bar{\delta}_{\mathrm{AB}}=0.39$ ppm). The indenyl proton $\mathrm{H}^{2}$ appears at low field (18: $6.38 \mathrm{ppm}$, 19: $6.26 \mathrm{ppm}$ ) that is consistent with $\eta^{3}$-coordination mode. In case of the compound 18, the proposed molecular structure was confirmed in solid state by X-ray diffraction analysis, see Figure 11. The molecule has a distorted octahedral structure of approximate $C_{\mathrm{s}}$ symmetry. The tridentate indenyl ligand is coordinated symmetrically as revealed from similar bond lengths Mo-N, see Table 3. The $\eta^{3}$-coordination mode of indenyl is evidenced by high values of ring slip parameters $\Omega$ [26.9(3) $]$ and $\Delta(\mathrm{M}-\mathrm{C})[0.842(3) \AA \AA]$.

\section{Theoretical studies}

Unusually high stability of the $\eta^{3}$-indenyl molybdenum compounds led us to theoretical investigation of haptotropic rearrangement for the compound $\mathbf{1 4}$. From mechanistic point of view, the rearrangement should be associated with abstraction of one acetonitrile ligand to obey $18 \mathrm{e}$ rule. ${ }^{[16]}$ Before exploration of the putative pathways for the species 14, the energy profile of indenyl molybdenum species without intramolecular interaction, $\left[\left(\eta^{3}-\right.\right.$ Ind $\left.) \mathrm{Mo}(\mathrm{CO})_{2}(\mathrm{NCMe})_{3}\right]\left[\mathrm{BF}_{4}\right]$, was investigated. It will be used for comparative purposes since preceding experimental study provides a clear identification of equilibrium reaction between $\mathbf{A}$ and $\mathbf{D}{ }^{{ }^{[25]}}$ We note that this system was previously a subject of theoretical studies ${ }^{[10,26]}$ but full energy profile of the rearrangement is still missing. The minima and the transition states were optimized at density functional level of theory (B3LYP) and the corresponding structures are shown in the energy profiles together with selected geometric parameters. The energy is always referred to the starting compound.

The mechanism of the haptotropic rearrangement for $\left[\left(\eta^{3}\right.\right.$ Ind) $\left.\mathrm{Mo}(\mathrm{CO})_{2}(\mathrm{NCMe})_{3}\right]\left[\mathrm{BF}_{4}\right]$ is shown in Figure 12 . In accordance with previous theoretical studies, $\left.{ }^{10}, 26\right]$ the hexacoordinated species with $\mathrm{C}_{6}$-ring of indenyl ligand above carbonyls (A) shows lowest electronic energy. Nevertheless, the product of rearrangement $\left[\left(\eta^{5}-\mathrm{Ind}\right) \mathrm{Mo}(\mathrm{CO})_{2}(\mathrm{NCMe})_{2}\right]\left[\mathrm{BF}_{4}\right]$, appearing via dissociative mechanism, is favored at room temperature on entropic grounds as revealed from negative value of Gibbs free energy obtained for conformer ' $D^{\prime}(\Delta G=-8.3$ $\left.\mathrm{kcal} \cdot \mathrm{mol}^{-1}\right)$. The spontaneous release of acetonitrile well correlates with our recent experiments those give single crystals of ' $\mathbf{D}$ ' from acetonitrile solution. ${ }^{[27]}$

Since opposite orientation of the indenyl ligand toward $\mathrm{Mo}(\mathrm{CO})_{2}$ moiety is observed for the species A and $\mathbf{D}^{\prime}$, the haptotropic rearrangement have to include the $180^{\circ}$ rotation of the indenyl ligand. The rotation barrier of $\eta^{3}$-bonded indenyl ligand is 9.3 $\mathrm{kcal} \cdot \mathrm{mol}^{-1}$. The conformer with the indenyl rotated $\sim 90^{\circ}$ (B) has an energy $5.9 \mathrm{kcal} \cdot \mathrm{mol}^{-1}$ and the conformer $\mathbf{C}$ with $180^{\circ}$ rotation ( $\mathrm{C}_{6}$-ring trans to carbonyls) $7.8 \mathrm{kcal} \cdot \mathrm{mol}^{-1}$. The rotation of the $\eta^{5}$ bonded indenyl ligand in pentacoordinated species D' is also kinetically allowed as evidenced by low energy barrier of 8.5 $\mathrm{kcal} \cdot \mathrm{mol}^{-1}$. The transition states of ring slippage step were calculated for three pairs of conformers with the same orientation of indenyl ligand ( $\mathbf{T S} \mathbf{A F}_{\mathrm{AF}}, \mathbf{T S}_{\mathrm{BE}}$ and $\mathbf{T} \mathbf{S}_{\mathrm{CD}}$ ). The lowest barrier $\left(16.9 \mathrm{kcal} \cdot \mathrm{mol}^{-1}\right)$ appears between conformers $\mathbf{C}$ and $\mathbf{D}$ having $\mathrm{C}_{6}$-ring of indenyl ligand trans to carbonyl ligands. In appropriate transition state $\left(\mathbf{T S}_{\mathbf{C D}}\right)$, the indenyl ring slips from $\eta^{3}$ to $\eta^{5}$, as evidenced by folding angle $(\Omega)$ of $15.6^{\circ}$, while 
dissociation of the Mo- $\mathrm{N}_{\mathrm{ax}}$ bond is underway with a distance of $2.93 \AA$ and a Wiberg index (WI) ${ }^{[28]}$ of 0.23 , indicating a weak interaction. The pathways of the ring slippage starting from conformers $\mathbf{A}$ and $\mathbf{B}$ are kinetically disfavored owing to considerably higher activation energies $\left(\mathrm{TS}_{\mathrm{AF}}\right.$ : $33.1 \mathrm{kcal} \cdot \mathrm{mol}^{-1}$;
$\left.\mathrm{TS}_{\mathrm{BE}}: 24.5 \mathrm{kcal} \cdot \mathrm{mol}^{-1}\right)$. Consequently, the preferred pathway comprises $180^{\circ}$ rotation of $\eta^{3}$-bonded indenyl ligand $(\mathbf{A} \rightarrow \mathbf{B} \rightarrow$ C) followed with $\eta^{3}$ to $\eta^{5}$ indenyl ring slippage accompanied with acetonitrile abstraction (C $\rightarrow$ D') that is a rate determining step.

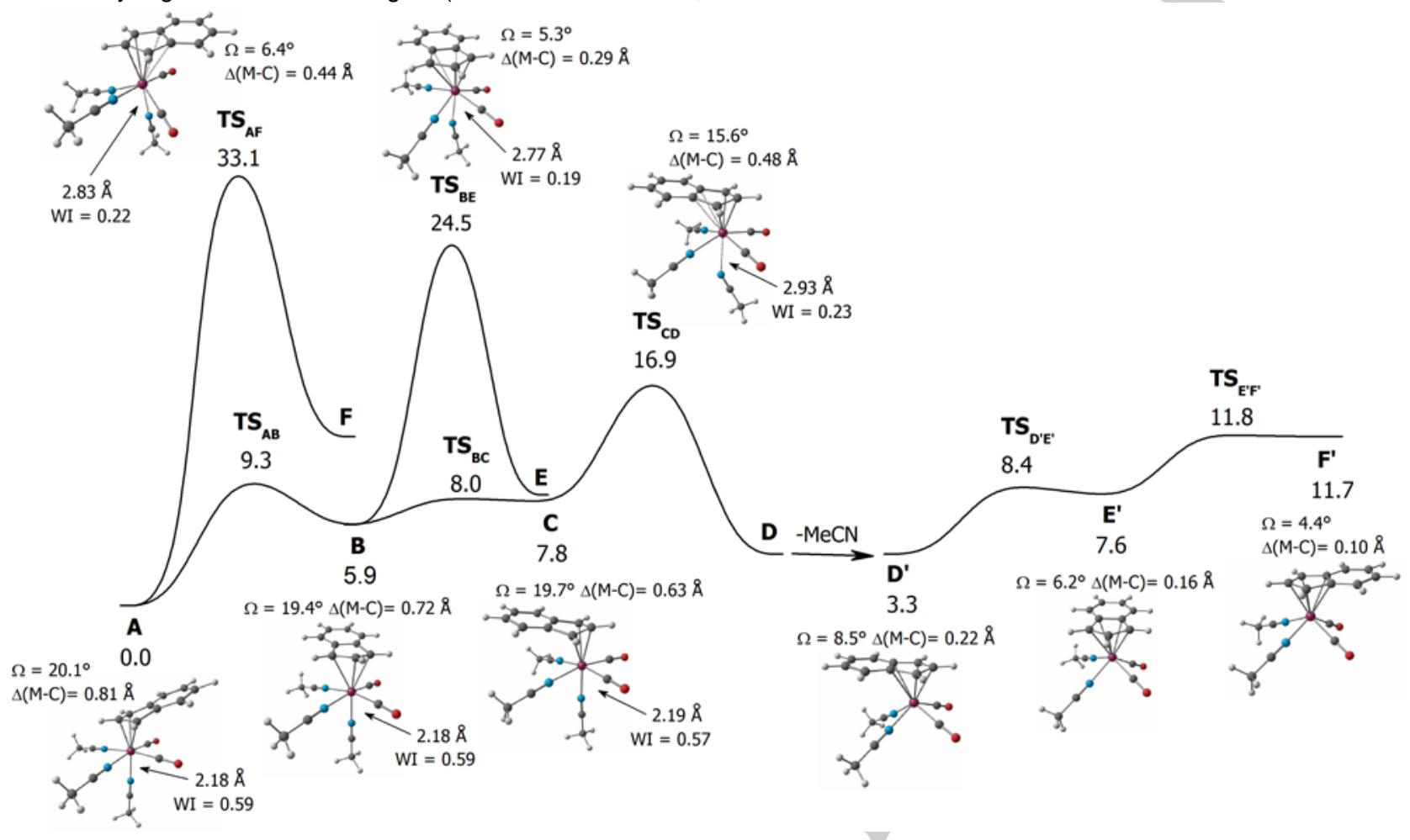

Figure 12. Energy profile (B3LYP) for haptotropic rearrangement of the indenyl ligand in molybdenum $\mathrm{complex}\left[\left(\eta^{3}-\mathrm{Ind}\right) \mathrm{Mo}(\mathrm{CO})_{2}(\mathrm{NCMe})_{3}\right]\left[\mathrm{BF} \mathrm{F}_{4}\right]$. The energy is given in $\mathrm{kcal} \cdot \mathrm{mol}^{-1}$ and referred to reagent $\mathbf{A}$. The structures of transition states related to indenyl rotation $\left(\mathbf{T S}_{\mathrm{AB}^{\mathrm{B}}}, \mathbf{T S}_{\mathrm{BC},}, \mathbf{T S}_{\mathrm{D}^{\prime} \mathrm{E}^{\prime}}\right.$ and $\left.\mathbf{T S} \mathbf{E}_{\mathrm{E}^{\prime} \mathrm{F}^{\prime}}\right)$ are omitted for clarity.

In case of compound 14, the observed isomer with $\mathrm{C}_{6}$-ring of indenyl ligand above carbonyls (14-A), is thermodynamically favored as confirmed by theoretical calculations. Hence, the virtual isomer with $\mathrm{C}_{6}$-ring above $\mathrm{Mo}(\mathrm{CO})(\mathrm{NCMe})$ moiety (14-B) is $5.0 \mathrm{kcal} \cdot \mathrm{mol}^{-1}$ less stable $\left(\Delta \mathrm{G}=5.2 \mathrm{kcal} \cdot \mathrm{mol}^{-1}\right)$. We note that further suggested isomer with $\mathrm{C}_{6}$-ring trans to carbonyls is not an energetic minimum due to strain of the coordinated pyridine arm. As the rotation of the indenyl ligand is restricted by strong intramolecular interaction, the observed species 14-A could only rearrange to $14 C^{\prime}$ ' while the thermodynamically favored product 14D' is only available from virtual isomer 14-B, see Figure 13. The transition $\mathbf{1 4 - A} \rightarrow \mathbf{1 4} \mathbf{C}^{\prime}$ is not kinetically allowed due to high activation energy $\left(41.7 \mathrm{kcal} \cdot \mathrm{mol}^{-1}\right)$. In accordance to aforementioned system without intramolecular coordination, the $\eta^{3}$ to $\eta^{5}$ slippage is more convenient in the other orientations of the indenyl ligand. Hence, the transition 14-B $\rightarrow$ 14D' shows considerably lower activation energy $\left(17.5 \mathrm{kcal} \cdot \mathrm{mol}^{-1}\right)$ and significant free energy gain $\left(\Delta G=-9.9 \mathrm{kcal} \cdot \mathrm{mol}^{-1}\right)$. As the isomer for the kinetically allowed pathway (14-B) is not available in the reaction mixture, the $\eta^{3}$ to $\eta^{5}$ cannot proceed under mild conditions.

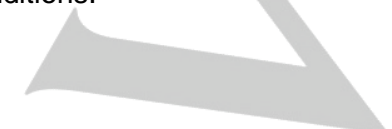

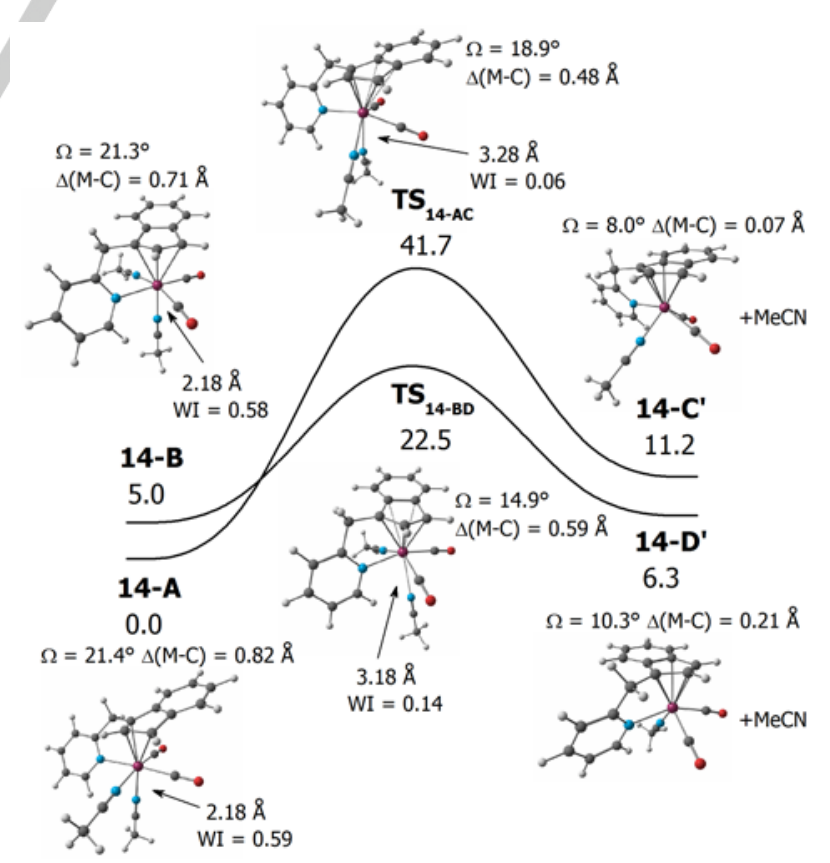

Figure 13. Energy profile (B3LYP) of haptotropic rearrangement of the indenyl ligand in complex 14 . The energy is given in $\mathrm{kcal} \cdot \mathrm{mol}^{-1}$ and referred to reagent 14-A. 


\section{Conclusions}

In conclusion, we have demonstrated an unusual example of indenyl effect on cyclopentadienyl and indenyl molybdenum compounds with pyridine in the side chain (7 and 8). Although the species are isostructural, their reactivity differs considerably. The cyclopentadienyl compound $\mathbf{7}$ produces rather convenient pentacoordinated $\eta^{5}: K N$-species $\mathbf{1 1}$ while hexacoordinated species with unprecedented $\eta^{3}: k N$-coordination mode 14 was synthesized from the indenyl analogue 8 under similar reaction conditions. Further experiments, performed on both products, have confirmed the irreversible character of intramolecular coordination. The unusually high stability of indenyl complex 14 toward $\eta^{3}$ to $\eta^{5}$ haptotropic rearrangement was clarified by theoretical calculations. Since strong intramolecular interaction prevents rotation of indenyl ligand, it cannot achieve conformation suitable for haptotropic rearrangement. Thus, the intramolecular coordination performs as a lock preserving low hapticity of the indenyl ligand.

\section{Experimental Section}

Methods and materials. All operations were performed under nitrogen atmosphere using conventional Schlenk-line techniques. The solvents were purified and dried by standard methods. ${ }^{[29]}$ Starting materials were available commercially or prepared according to literature procedures: $\mathrm{NaCp}(\mathbf{1}),{ }^{[30]} \mathrm{Nalnd}(\mathbf{2}),{ }^{[31]}\left[\left(\eta^{3}-\mathrm{C}_{3} \mathrm{H}_{5}\right) \mathrm{Mo}(\mathrm{CO})_{2}(\mathrm{NCMe})_{2} \mathrm{Cl}\right](\mathbf{6}) .{ }^{[15]}$

Measurements. Infrared and Raman spectra were recorded on a Nicolet iS50 FTIR spectrometer equipped a Raman module (Nd:YAG laser emitting at $1064 \mathrm{~cm}^{-1}$ ). The infrared spectra were recorded in the $4000-400 \mathrm{~cm}^{-1}$ region (resolution $1 \mathrm{~cm}^{-1}$ ) using Diamond Smart Orbit ATR. Raman spectra were recorded in the $4000-100 \mathrm{~cm}^{-1}$ region (resolution $2 \mathrm{~cm}^{-1}$ ) in glass capillaries. The ${ }^{1} \mathrm{H}$ and ${ }^{13} \mathrm{C}\left\{{ }^{1} \mathrm{H}\right\}$ NMR spectra were recorded on a Bruker Avance 400 and Bruker Avance 500 spectrometers at $300 \mathrm{~K}$ in $\mathrm{CDCl}_{3}, \mathrm{CD}_{3} \mathrm{CN}$, acetone- $\mathrm{d}_{6}$ and DMSO- $\mathrm{d}_{6}$. The chemical shifts are given in ppm relative to TMS. Mass spectrometry was performed on a quadruple mass spectrometer (LCMS 2010, Shimadzu, Japan). The sample was injected into the mass spectrometer with infusion mode at a constant flow rate of $10 \mu \mathrm{L} / \mathrm{min}$. Electrospray ionization-mass spectrometry (ESI-MS) was used for the identification of analyzed samples.

Synthesis of $\mathbf{C}_{5} \mathrm{H}_{4} \mathrm{NCH}_{2} \mathrm{Cl}$. A solution of $\mathrm{KOH}(15 \mathrm{~g}, 0.27 \mathrm{~mol})$ in distilled water $(150 \mathrm{~mL})$ was cooled to $0^{\circ} \mathrm{C}$ and treated with $\mathrm{C}_{5} \mathrm{H}_{4} \mathrm{NCH}_{2} \mathrm{Cl} \cdot \mathrm{HCl}(21.3 \mathrm{~g}, 0.13 \mathrm{~mol})$. The reaction mixture was extracted with $\mathrm{CH}_{2} \mathrm{Cl}_{2}(4 \times 50 \mathrm{~mL})$ and combined organic layers were dried with magnesium sulfate. The volatiles were evaporated on rotavapor and the crude product was vacuum distilled at $74^{\circ} \mathrm{C}$ (10 Torr). Yield: $14.9 \mathrm{~g}$ (0.12 $\mathrm{mol}, 90 \%)$. Colorless liquid. Analytical and spectroscopic data are in line with those published elsewhere. ${ }^{[32]}$

Synthesis of $\mathrm{C}_{5} \mathrm{H}_{4} \mathrm{NCH}_{2} \mathrm{C}_{5} \mathrm{H}_{5}$ (3). A solution of $\mathrm{NaCp} \mathrm{(1;} 4.40 \mathrm{~g}, 50$ mmol) in THF $(150 \mathrm{~mL})$ was cooled to $0^{\circ} \mathrm{C}$, treated with $\mathrm{C}_{5} \mathrm{H}_{4} \mathrm{NCH}_{2} \mathrm{Cl}$ $(5.87 \mathrm{~g}, 46 \mathrm{mmol})$ dropwise and stirred at room temperature overnight. The reaction mixture was poured into distilled water $(75 \mathrm{~mL})$ and crude product was extracted with $\mathrm{CH}_{2} \mathrm{Cl}_{2}(4 \times 50 \mathrm{~mL})$. Combined organic layers were dried with magnesium sulfate. The volatiles were evaporated on rotavapor and the crude product was vacuum distilled using Kugelrohr apparatus $\left(150^{\circ} \mathrm{C}, 10\right.$ Torr). Yield: $4.55 \mathrm{~g}(29 \mathrm{mmol}, 63 \%)$. Pale yellow liquid. Analytical and spectroscopic data are in line with those published elsewhere. ${ }^{[33]}$
Synthesis of $3-\left(\mathrm{C}_{5} \mathrm{H}_{4} \mathrm{NCH}_{2}\right) \mathrm{C}_{9} \mathrm{H}_{7}$ (4). The reaction was carried out as described for compound 3 but with Nalnd (2; $6.91 \mathrm{~g}, 50 \mathrm{mmol})$. The crude product was vacuum distilled using Kugelrohr apparatus $\left(300^{\circ} \mathrm{C}, 6\right.$ Pa). Yield: $4.00 \mathrm{~g}(19 \mathrm{mmol}, 42 \%)$. Orange liquid. Analytical and spectroscopic data are in line with those published elsewhere. ${ }^{[33]}$

Synthesis of 1-D-3-( $\left.\mathrm{C}_{5} \mathrm{H}_{4} \mathrm{NCH}_{2}\right) \mathrm{C}_{9} \mathrm{H}_{6} \quad$ (4-D). A solution of 3- $\left(\mathrm{C}_{5} \mathrm{H}_{4} \mathrm{NCH}_{2}\right) \mathrm{C}_{9} \mathrm{H}_{7}(4 ; 5.18 \mathrm{~g}, 25 \mathrm{mmol})$ in THF (30 mL) was cooled to $0^{\circ} \mathrm{C}$, treated with a solution of ${ }^{\mathrm{n}} \mathrm{BuLi}$ in hexane $(15.6 \mathrm{~mL}, 1.6 \mathrm{~mol} / \mathrm{L}, 25$ $\mathrm{mmol}$ ) dropwise and stirred for $30 \mathrm{~min}$. at this temperature. The reaction mixture was treated with $\mathrm{D}_{2} \mathrm{O}(3 \mathrm{~mL}, 165 \mathrm{mmol})$ dropwise, allowed to warm up to room temperature, slowly poured into distillated water (50 $\mathrm{mL})$ and extracted with $\mathrm{CH}_{2} \mathrm{Cl}_{2}(4 \times 50 \mathrm{~mL})$. Combined organic layers were dried with magnesium sulfate. The volatiles were evaporated on rotavapor and the product was vacuum distilled using Kugelrohr apparatus $\left(240^{\circ} \mathrm{C}, 6 \mathrm{~Pa}\right)$. Yield: $4.4 \mathrm{~g}(21 \mathrm{mmol}, 72 \%)$. Orange liquid. ${ }^{1} \mathrm{H}$ NMR $\left(\mathrm{CDCl}_{3}, 400.13 \mathrm{MHz}\right): \delta=3.44\left(\mathrm{~m}, 1 \mathrm{H}, \mathrm{H}^{1}, \mathrm{C}_{9} \mathrm{H}_{6}\right), 4.20(\mathrm{~s}, 2 \mathrm{H}$, $\left.\mathrm{CH}_{2}\right), 6.33\left(\mathrm{~m}, 1 \mathrm{H}, \mathrm{H}^{2}, \mathrm{C}_{9} \mathrm{H}_{6}\right), 7.20\left(\mathrm{ddd},{ }^{3} \mathrm{~J}\left({ }^{1} \mathrm{H},{ }^{1} \mathrm{H}\right)=7.5 \mathrm{~Hz},{ }^{3} \mathrm{~J}\left({ }^{1} \mathrm{H},{ }^{1} \mathrm{H}\right)=\right.$ $\left.5.1 \mathrm{~Hz},{ }^{4} \mathrm{~J}\left({ }^{1} \mathrm{H},{ }^{1} \mathrm{H}\right)=0.7 \mathrm{~Hz}, 1 \mathrm{H}, \mathrm{H}^{4 / 5}, \mathrm{C}_{5} \mathrm{H}_{4} \mathrm{~N}\right), 7.24-7.35\left(\mathrm{~m}, 3 \mathrm{H}, \mathrm{H}^{4-7}\right.$ $\left.\mathrm{C}_{9} \mathrm{H}_{6}\right), 7.39\left(\mathrm{~d},{ }^{3} \mathrm{~J}\left({ }^{1} \mathrm{H},{ }^{1} \mathrm{H}\right)=7.6 \mathrm{~Hz}, \mathrm{H}^{4 / 7}, \mathrm{C}_{9} \mathrm{H}_{6}\right), 7.53\left(\mathrm{~d},{ }^{3} \mathrm{~J}\left({ }^{1} \mathrm{H},{ }^{1} \mathrm{H}\right)=7.6\right.$ $\left.\mathrm{Hz}, \mathrm{H}^{3 / 6}, \mathrm{C}_{5} \mathrm{H}_{4} \mathrm{~N}\right), 7.63\left(\mathrm{td},{ }^{3} \mathrm{~J}\left({ }^{1} \mathrm{H},{ }^{1} \mathrm{H}\right)=7.6 \mathrm{~Hz},{ }^{4} \mathrm{~J}\left({ }^{1} \mathrm{H},{ }^{1} \mathrm{H}\right)=1.7 \mathrm{~Hz}, \mathrm{H}^{4 / 5}\right.$, $\left.\mathrm{C}_{5} \mathrm{H}_{4} \mathrm{~N}\right), 8.65\left(\mathrm{~d},{ }^{3} \mathrm{~J}\left({ }^{1} \mathrm{H},{ }^{1} \mathrm{H}\right)=4.6 \mathrm{~Hz}, \mathrm{H}^{3 / 6}, \mathrm{C}_{5} \mathrm{H}_{4} \mathrm{~N}\right)$.

Synthesis of 1-( $\left.\mathrm{C}_{5} \mathrm{H}_{4} \mathrm{NCH}\right) \mathrm{C}_{9} \mathrm{H}_{6}$ (4'). A solution of sodium methanolate $(10.8 \mathrm{~g}, 200 \mathrm{mmol})$ in methanol $(250 \mathrm{~mL})$ was treated with indene $(10 \mathrm{~mL}$, $86 \mathrm{mmol}$ ) and 2-pyridinecarboxaldehyde (5.68 g, $53 \mathrm{mmol})$. The reaction mixture was heated under reflux for $1 \mathrm{~h}$ and then stirred at room temperature overnight. The solution was diluted with water $(300 \mathrm{~mL})$ and extracted with pentane $(5 \times 200 \mathrm{~mL})$. The combined organic layers were dried with magnesium sulfate and volatiles were vacuum evaporated on rotavapor. The crude product was purified by column chromatography on silica (hexane : $\mathrm{Et}_{2} \mathrm{O}-1$ : 1). Yield: $5.22 \mathrm{~g} \mathrm{(25} \mathrm{mmol,} \mathrm{48 \% ).} \mathrm{Yellow}$ crystals. Mp: $114{ }^{\circ} \mathrm{C}$. Anal. Calcd. for $\mathrm{C}_{15} \mathrm{H}_{11} \mathrm{~N}$ : C, 87.77; $\mathrm{H}, 5.40 ; \mathrm{N}, 6.83$. Found: $\mathrm{C}, 87.59 ; \mathrm{H}, 5.36 ; \mathrm{N}, 6.91 .{ }^{1} \mathrm{H} \mathrm{NMR}\left(\mathrm{CDCl}_{3} ; 500.20 \mathrm{MHz}\right): \delta=$ $7.06\left(\mathrm{dd},{ }^{3} \mathrm{~J}\left({ }^{1} \mathrm{H},{ }^{1} \mathrm{H}\right)=5.6 \mathrm{~Hz},{ }^{4} \mathrm{~J}\left({ }^{1} \mathrm{H},{ }^{1} \mathrm{H}\right)=1.5 \mathrm{~Hz}, 1 \mathrm{H}, \mathrm{H}^{3}, \mathrm{C}_{9} \mathrm{H}_{6}\right), 7.21-$ $7.34\left(\mathrm{~m}, 1 \mathrm{H}\right.$ of $\mathrm{C}_{5} \mathrm{H}_{4} \mathrm{~N}, \mathrm{H}^{5}$ and $3 \mathrm{H}$ of $\left.\mathrm{C}_{9} \mathrm{H}_{6}, \mathrm{H}^{4-7}\right), 7.41(\mathrm{~s}, 1 \mathrm{H}$, $\left.\mathrm{C}_{9} \mathrm{H}_{6} \mathrm{CHC}_{5} \mathrm{H}_{4} \mathrm{~N}\right), 7.56\left(\mathrm{~d},{ }^{3} \mathrm{~J}\left({ }^{1} \mathrm{H},{ }^{1} \mathrm{H}\right)=7.9 \mathrm{~Hz}, 1 \mathrm{H}, \mathrm{H}^{3}, \mathrm{C}_{5} \mathrm{H}_{4} \mathrm{~N}\right), 7.65$ $\left(\mathrm{d},{ }^{3} \mathrm{~J}\left({ }^{1} \mathrm{H},{ }^{1} \mathrm{H}\right)=5.6 \mathrm{~Hz}, 1 \mathrm{H}, \mathrm{H}^{2}, \mathrm{C}_{9} \mathrm{H}_{6}\right), 7.71\left(\mathrm{~d},{ }^{3} \mathrm{~J}\left({ }^{1} \mathrm{H},{ }^{1} \mathrm{H}\right)=7.3 \mathrm{~Hz}, 1 \mathrm{H}\right.$ $\left.\mathrm{H}^{4 / 7}, \mathrm{C}_{9} \mathrm{H}_{6}\right), 7.75\left(\mathrm{ddd},{ }^{3} \mathrm{~J}\left({ }^{1} \mathrm{H},{ }^{1} \mathrm{H}\right)=7.9 \mathrm{~Hz},{ }^{3} \mathrm{~J}\left({ }^{1} \mathrm{H},{ }^{1} \mathrm{H}\right)=7.6 \mathrm{~Hz},{ }^{4} \mathrm{~J}\left({ }^{1} \mathrm{H},{ }^{1} \mathrm{H}\right)=\right.$ $\left.1.9 \mathrm{~Hz}, 1 \mathrm{H}, \mathrm{H}^{4}, \mathrm{C}_{5} \mathrm{H}_{4} \mathrm{~N}\right), 8.75$ (ddd, ${ }^{3} \mathrm{~J}\left({ }^{1} \mathrm{H},{ }^{1} \mathrm{H}\right)=4.8 \mathrm{~Hz},{ }^{4} \mathrm{~J}\left({ }^{1} \mathrm{H},{ }^{1} \mathrm{H}\right)=1.7$ $\left.\mathrm{Hz},{ }^{5} \mathrm{~J}\left({ }^{1} \mathrm{H},{ }^{1} \mathrm{H}\right)=0.8 \mathrm{~Hz}, 1 \mathrm{H}, \mathrm{H}^{6}, \mathrm{C}_{5} \mathrm{H}_{4} \mathrm{~N}\right) .{ }^{13} \mathrm{C}\left\{{ }^{1} \mathrm{H}\right\} \mathrm{NMR}\left(\mathrm{CDCl}_{3} ; 125.77\right.$ $\mathrm{MHz}): \delta=119.7\left(1 \mathrm{C}, \mathrm{C}^{4 / 7}, \mathrm{C}_{9} \mathrm{H}_{6}\right), 121.3\left(1 \mathrm{C}, \mathrm{C}^{5 / 6}, \mathrm{C}_{9} \mathrm{H}_{6}\right), 122.6\left(1 \mathrm{C}, \mathrm{C}^{4 / 7}\right.$, $\left.\mathrm{C}_{9} \mathrm{H}_{6}\right), 125.6\left(1 \mathrm{C}, \mathrm{C}^{5}, \mathrm{C}_{5} \mathrm{H}_{4} \mathrm{~N}\right), 125.9\left(1 \mathrm{C}, \mathrm{C}_{9} \mathrm{H}_{6} \mathrm{CHC}_{5} \mathrm{H}_{4} \mathrm{~N}\right), 126.2$ (1C $\left.\mathrm{C}^{3}, \mathrm{C}_{5} \mathrm{H}_{4} \mathrm{~N}\right), 127.6\left(1 \mathrm{C}, \mathrm{C}^{2}, \mathrm{C}_{9} \mathrm{H}_{6}\right), 128.4\left(1 \mathrm{C}, \mathrm{C}^{5 / 6}, \mathrm{C}_{9} \mathrm{H}_{6}\right), 136.1\left(1 \mathrm{C}, \mathrm{C}^{3}\right.$, $\left.\mathrm{C}_{9} \mathrm{H}_{6}\right), 136.9\left(1 \mathrm{C}, \mathrm{C}^{4}, \mathrm{C}_{5} \mathrm{H}_{4} \mathrm{~N}\right), 150.0\left(1 \mathrm{C}, \mathrm{C}^{6}, \mathrm{C}_{5} \mathrm{H}_{4} \mathrm{~N}\right), 137.8,142.7$, $143.2\left(3 \times 1 \mathrm{C}_{\mathrm{q}}, \mathrm{C}_{9} \mathrm{H}_{6}\right), 155.7\left(1 \mathrm{C}_{\mathrm{q}}, \mathrm{C}^{2}, \mathrm{C}_{5} \mathrm{H}_{4} \mathrm{~N}\right)$. Single crystals suitable for $\mathrm{X}$-ray diffraction analysis were prepared by a slow evaporation of $\mathrm{Et}_{2} \mathrm{O}$ solution.

Synthesis of 1,3-( $\left(\mathrm{C}_{5} \mathrm{H}_{4} \mathrm{NCH}_{2}\right)_{2} \mathrm{C}_{9} \mathrm{H}_{6} \quad$ (5). A solution of 3- $\left(\mathrm{C}_{5} \mathrm{H}_{4} \mathrm{NCH}_{2}\right) \mathrm{C}_{9} \mathrm{H}_{7}(4 ; 5.18 \mathrm{~g}, 25 \mathrm{mmol})$ was cooled to $0^{\circ} \mathrm{C}$, treated with a solution of ${ }^{\mathrm{n}} \mathrm{BuLi}$ in hexane $(15.6 \mathrm{~mL}, 1.6 \mathrm{~mol} / \mathrm{L}, 25 \mathrm{mmol})$ dropwise and stirred for $30 \mathrm{~min}$. at this temperature. The reaction mixture was treated with $\mathrm{C}_{5} \mathrm{H}_{4} \mathrm{NCH}_{2} \mathrm{Cl}(3.10 \mathrm{~g}, 25 \mathrm{mmol})$ dropwise, stirred at room temperature overnight and then poured into distilled water $(75 \mathrm{~mL})$. Crude product was extracted with $\mathrm{CH}_{2} \mathrm{Cl}_{2}$. Combined organic layers were dried with magnesium sulfate. The volatiles were evaporated on the rotavapor and crude product was purified by column chromatography on silica (ethyl acetate). Yield: $1.56 \mathrm{~g}$ (5.2 mmol, 21\%). Pale yellow liquid. Anal. Calcd. for $\mathrm{C}_{15} \mathrm{H}_{11} \mathrm{~N}$ : C, 86.50; $\mathrm{H}, 6.77 ; \mathrm{N}, 6.73$. Found: $\mathrm{C}, 86.67 ; \mathrm{H}$, 6.69; N, 6.85. ${ }^{1} \mathrm{H}$ NMR $\left(\mathrm{CDCl}_{3}, 400.13 \mathrm{MHz}\right): \delta=2.91\left(\mathrm{dd},{ }^{2} \mathrm{~J}\left({ }^{1} \mathrm{H},{ }^{1} \mathrm{H}\right)=\right.$ $\left.13.5 \mathrm{~Hz}, \quad{ }^{3} \mathrm{~J}\left({ }^{1} \mathrm{H},{ }^{1} \mathrm{H}\right)=8.8 \mathrm{~Hz}, \quad 1 \mathrm{H}, \quad 1-\left(\mathrm{C}_{5} \mathrm{H}_{4} \mathrm{NCH}_{2}\right) \mathrm{C}_{9} \mathrm{H}_{6}\right), \quad 3.25$ $\left(\mathrm{dd},{ }^{2} \mathrm{~J}\left({ }^{1} \mathrm{H},{ }^{1} \mathrm{H}\right)=13.5 \mathrm{~Hz},{ }^{3} \mathrm{~J}\left({ }^{1} \mathrm{H},{ }^{1} \mathrm{H}\right)=6.7 \mathrm{~Hz}, 1 \mathrm{H}, 1-\left(\mathrm{C}_{5} \mathrm{H}_{4} \mathrm{NCH}_{2}\right) \mathrm{C}_{9} \mathrm{H}_{6}\right)$, $4.02\left(\mathrm{dd},{ }^{3} \mathrm{~J}\left({ }^{1} \mathrm{H},{ }^{1} \mathrm{H}\right)=8.8 \mathrm{~Hz},{ }^{3} \mathrm{~J}\left({ }^{1} \mathrm{H},{ }^{1} \mathrm{H}\right)=6.7 \mathrm{~Hz}, 1 \mathrm{H}, \mathrm{C}_{9} \mathrm{H}_{6}\right), 4.06(\mathrm{~s}, 2 \mathrm{H}$, 3- $\left.\left(\mathrm{C}_{5} \mathrm{H}_{4} \mathrm{NCH}_{2}\right) \mathrm{C}_{9} \mathrm{H}_{6}\right), 6.20\left(\mathrm{~s}, 1 \mathrm{H}, \mathrm{H}^{2}, \mathrm{C}_{9} \mathrm{H}_{6}\right), 7.04-7.24\left(\mathrm{~m}, 8 \mathrm{H}, \mathrm{H}^{3,4}\right.$ of $\left(\mathrm{C}_{5} \mathrm{H}_{4} \mathrm{NCH}_{2}\right)_{2} \mathrm{C}_{9} \mathrm{H}_{6}, \mathrm{H}^{4-7}$ of $\left.\mathrm{C}_{9} \mathrm{H}_{6}\right), 7.51,7.57\left(2 \times \mathrm{td},{ }^{3} \mathrm{~J}\left({ }^{1} \mathrm{H},{ }^{1} \mathrm{H}\right)=7.6\right.$ $\left.\mathrm{Hz},{ }^{4} \mathrm{~J}\left({ }^{1} \mathrm{H},{ }^{1} \mathrm{H}\right)=1.5 \mathrm{~Hz}, 2 \mathrm{H}, \mathrm{H}^{5}, \mathrm{C}_{5} \mathrm{H}_{4} \mathrm{~N}\right), 8.53,8.59\left(2 \times \mathrm{d},{ }^{3} \mathrm{~J}\left({ }^{1} \mathrm{H},{ }^{1} \mathrm{H}\right)=4.7\right.$ $\left.\mathrm{Hz}, 2 \mathrm{H}, \mathrm{H}^{6}, \mathrm{C}_{5} \mathrm{H}_{4} \mathrm{~N}\right) .{ }^{13} \mathrm{C}\left\{{ }^{1} \mathrm{H}\right\}$ NMR $\left(\mathrm{CDCl}_{3}, 100.61 \mathrm{MHz}\right): \delta=37.4,40.4$ $\left(2 \times 1 \mathrm{C}, \mathrm{CH}_{2}\right), 49.2\left(1 \mathrm{C}, \mathrm{C}^{1}, \mathrm{C}_{9} \mathrm{H}_{6}\right), 119.9,121.4,121.6,122.9,123.2$, 
$123.7,124.9,126.7,135.6,136.4,136.6,149.3,149.4\left(13 \times 1 C, C^{2,4-7}\right.$ of $\mathrm{C}_{9} \mathrm{H}_{6}, \mathrm{C}^{3-6}$ of $\left(\mathrm{C}_{5} \mathrm{H}_{4} \mathrm{NCH}_{2}\right)_{2} \mathrm{C}_{9} \mathrm{H}_{6}, 140.9,144.5,147.9\left(3 \times 1 \mathrm{C}_{\mathrm{q}}, \mathrm{C}^{3,3 \mathrm{~A}, 7 \mathrm{~A}}\right.$, $\left.\mathrm{C}_{9} \mathrm{H}_{6}\right), 159.5,160.3\left(2 \times 1 \mathrm{C}_{\mathrm{q}}, \mathrm{C}^{2},\left(\mathrm{C}_{5} \mathrm{H}_{4} \mathrm{NCH}_{2}\right)_{2} \mathrm{C}_{9} \mathrm{H}_{6}\right)$.

Synthesis of $\left[\left(\eta^{3}-\mathrm{C}_{3} \mathrm{H}_{5}\right)\left(\eta^{5}-\mathrm{C}_{5} \mathrm{H}_{4} \mathrm{NCH}_{2} \mathrm{C}_{5} \mathrm{H}_{4}\right) \mathrm{Mo}(\mathrm{CO})_{2}\right]$ (7). A solution of $3(1.57 \mathrm{~g}, 10 \mathrm{mmol})$ in THF $(40 \mathrm{~mL})$ was cooled to $0^{\circ} \mathrm{C}$, treated with a solution of ${ }^{\mathrm{n}} \mathrm{BuLi}$ in hexane $(6.55 \mu \mathrm{L}, 1.6 \mathrm{~mol} / \mathrm{L}, 10 \mathrm{mmol})$ dropwise and stirred for $30 \mathrm{~min}$. at room temperature. The reaction mixture was cooled to $-80^{\circ} \mathrm{C}$ and treated with a solution of $\left[\left(\eta^{3}-\mathrm{C}_{3} \mathrm{H}_{5}\right) \mathrm{Mo}(\mathrm{CO})_{2}(\mathrm{NCMe})_{2} \mathrm{Cl}\right]$ $(3.1 \mathrm{~g}, 10 \mathrm{mmol})$ in THF $(30 \mathrm{~mL})$ dropwise. The mixture was stirred at room temperature overnight. The volatiles were vacuum evaporated and crude product was extracted with hexane $(3 \times 70 \mathrm{~mL})$ at $60^{\circ} \mathrm{C}$. The solvent was vacuum evaporated. The product was recrystallized from the mixture hexane $/ \mathrm{Et}_{2} \mathrm{O}$ at $-80^{\circ} \mathrm{C}$ and vacuum dried. Yield: $1.88 \mathrm{~g}(5.4$ mmol, 54\%). Yellow viscous liquid. Anal. Calcd. for $\mathrm{C}_{16} \mathrm{H}_{15} \mathrm{MoNO}_{2}$ : $\mathrm{C}$, 55.03; H, 4.33; N, 4.01. Found: C, 55.28; $\mathrm{H}, 4.48 ; \mathrm{N}, 3.86 .{ }^{1} \mathrm{H}$ NMR $\left(\mathrm{CDCl}_{3}, 400.13 \mathrm{MHz}, 3.5: 1\right.$ mixture of $\mathbf{7 a}\left(\right.$ exo- $\left.\mathrm{C}_{3} \mathrm{H}_{5}\right)$ and $\mathbf{7 b}$ (endo$\left.\left.\mathrm{C}_{3} \mathrm{H}_{5}\right)\right): \delta=0.88\left(\mathrm{~d},{ }^{3} \mathrm{~J}\left({ }^{1} \mathrm{H},{ }^{1} \mathrm{H}\right)=10.8 \mathrm{~Hz}, 2 \mathrm{H}\right.$ of $\left.\mathbf{a}, \mathrm{H}^{\text {anti }}, \mathrm{C}_{3} \mathrm{H}_{5}\right), 1.62$ $\left(\mathrm{d},{ }^{3} \mathrm{~J}\left({ }^{1} \mathrm{H},{ }^{1} \mathrm{H}\right)=10.3 \mathrm{~Hz}, 2 \mathrm{H}\right.$ of $\left.\mathbf{b}, \mathrm{H}^{\text {anti }}, \mathrm{C}_{3} \mathrm{H}_{5}\right), 2.66\left(\mathrm{~d},{ }^{3} \mathrm{~J}\left({ }^{1} \mathrm{H},{ }^{1} \mathrm{H}\right)=7.0 \mathrm{~Hz}\right.$, $2 \mathrm{H}$ of $\left.\mathbf{a}, \mathrm{H}^{\mathrm{syn}}, \mathrm{C}_{3} \mathrm{H}_{5}\right), 2.73\left(\mathrm{~s}-\mathrm{br}, 2 \mathrm{H}\right.$ of $\left.\mathbf{b}, \mathrm{H}^{\mathrm{syn}}, \mathrm{C}_{3} \mathrm{H}_{5}\right), 3.59(\mathrm{~m}, 1 \mathrm{H}$ of $\mathbf{b}$, $\left.\mathrm{H}^{\text {meso }}, \mathrm{C}_{3} \mathrm{H}_{5}\right), 3.66\left(\mathrm{~s}, 2 \mathrm{H}\right.$ of $\mathbf{a}$ and $2 \mathrm{H}$ of $\left.\mathbf{b}, \mathrm{CH}_{2}\right), 3.88\left(\mathrm{~m}, 1 \mathrm{H}\right.$ of $\mathbf{a}, \mathrm{H}^{\text {meso }}$, $\left.\mathrm{C}_{3} \mathrm{H}_{5}\right), 5.12\left(\mathrm{dd},{ }^{3} \mathrm{~J}\left({ }^{1} \mathrm{H},{ }^{1} \mathrm{H}\right)=2.1 \mathrm{~Hz},{ }^{4} \mathrm{~J}\left({ }^{1} \mathrm{H},{ }^{1} \mathrm{H}\right)=2.1 \mathrm{~Hz}, 2 \mathrm{H}\right.$ of a and $2 \mathrm{H}$ of $\left.\mathbf{b}, \mathrm{C}_{5} \mathrm{H}_{4}\right), 5.21\left(\mathrm{dd},{ }^{3} \mathrm{~J}\left({ }^{1} \mathrm{H},{ }^{1} \mathrm{H}\right)=2.1 \mathrm{~Hz},{ }^{4} \mathrm{~J}\left({ }^{1} \mathrm{H},{ }^{1} \mathrm{H}\right)=2.1 \mathrm{~Hz}, 2 \mathrm{H}\right.$ of $\mathbf{a}$ and $2 \mathrm{H}$ of $\left.\mathbf{b}, \mathrm{C}_{5} \mathrm{H}_{4}\right), 7.09$ (ddd, ${ }^{3} \mathrm{~J}\left({ }^{1} \mathrm{H},{ }^{1} \mathrm{H}\right)=7.5 \mathrm{~Hz},{ }^{3} \mathrm{~J}\left({ }^{1} \mathrm{H},{ }_{1} \mathrm{H}\right)=4.9 \mathrm{~Hz}$, ${ }^{4} \mathrm{~J}\left({ }^{1} \mathrm{H},{ }^{1} \mathrm{H}\right)=0.8 \mathrm{~Hz}, 1 \mathrm{H}$ of $\mathbf{a}$ and $1 \mathrm{H}$ of $\left.\mathbf{b}, \mathrm{H}^{5}, \mathrm{C}_{5} \mathrm{H}_{4} \mathrm{~N}\right), 7.12\left(\mathrm{~d},{ }^{3} \mathrm{~J}\left({ }^{1} \mathrm{H},{ }^{1} \mathrm{H}\right)=\right.$ $7.9 \mathrm{~Hz}, 1 \mathrm{H}$ of $\mathbf{a}$ and $1 \mathrm{H}$ of $\left.\mathbf{b}, \mathrm{H}^{3}, \mathrm{C}_{5} \mathrm{H}_{4} \mathrm{~N}\right), 7.56\left(\mathrm{ddd},{ }^{3} \mathrm{~J}\left({ }^{1} \mathrm{H},{ }^{1} \mathrm{H}\right)=7.9 \mathrm{~Hz}\right.$, ${ }^{3} \mathrm{~J}\left({ }^{1} \mathrm{H},{ }^{1} \mathrm{H}\right)=7.5 \mathrm{~Hz},{ }^{3} \mathrm{~J}\left({ }^{1} \mathrm{H},{ }^{1} \mathrm{H}\right)=1.8 \mathrm{~Hz}, 1 \mathrm{H}$ of $\mathbf{a}$ and $1 \mathrm{H}$ of $\left.\mathbf{b}, \mathrm{H}^{4}, \mathrm{C}_{5} \mathrm{H}_{4} \mathrm{~N}\right)$, $8.47\left(\mathrm{ddd},{ }^{3} \mathrm{~J}\left({ }^{1} \mathrm{H},{ }^{1} \mathrm{H}\right)=4.9 \mathrm{~Hz},{ }^{4} \mathrm{~J}\left({ }^{1} \mathrm{H},{ }^{1} \mathrm{H}\right)=1.8 \mathrm{~Hz},{ }^{5} \mathrm{~J}\left({ }^{1} \mathrm{H},{ }^{1} \mathrm{H}\right)=0.9 \mathrm{~Hz}, 1 \mathrm{H}\right.$ of $\mathbf{a}$ and $1 \mathrm{H}$ of $\left.\mathbf{b}, \mathrm{H}^{6}, \mathrm{C}_{5} \mathrm{H}_{4} \mathrm{~N}\right) .{ }^{13} \mathrm{C}\left\{{ }^{1} \mathrm{H}\right\} \mathrm{NMR}\left(\mathrm{CDCl}_{3}, 125.77 \mathrm{MHz}\right): \delta=$ $37.4\left(1 \mathrm{C}\right.$ of $\mathbf{a}$ and $\left.1 \mathrm{C} \mathbf{b}, \mathrm{CH}_{2}\right), 38.0\left(2 \mathrm{C}\right.$ of $\left.\mathbf{b}, \mathrm{C}^{1,3}, \mathrm{C}_{3} \mathrm{H}_{5}\right), 40.9(2 \mathrm{C}$ of $\mathbf{a}$, $\left.\mathrm{C}^{1,3}, \mathrm{C}_{3} \mathrm{H}_{5}\right), 68.7\left(1 \mathrm{C}\right.$ of a, $\left.\mathrm{C}^{2}, \mathrm{C}_{3} \mathrm{H}_{5}\right), 89.8\left(2 \mathrm{C}\right.$ of $\mathbf{a}$ and $\left.2 \mathrm{C} \mathrm{b}, \mathrm{C}_{4} \mathrm{H}_{5}\right)$, $92.4\left(2 \mathrm{C}\right.$ of $\mathbf{a}$ and $\left.2 \mathrm{C} \mathrm{b}, \mathrm{C}_{4} \mathrm{H}_{5}\right), 111.0\left(1 \mathrm{C}_{\mathrm{q}}\right.$ of $\mathbf{a}$ and $\left.1 \mathrm{C}_{\mathrm{q}} \mathbf{b}, \mathrm{C}_{4} \mathrm{H}_{5}\right), 121.6$ $\left(1 \mathrm{C}\right.$ of $\mathbf{a}$ and $\left.1 \mathrm{C} \mathbf{b}, \mathrm{C}^{5}, \mathrm{C}_{5} \mathrm{H}_{4} \mathrm{~N}\right), 122.7\left(1 \mathrm{C}\right.$ of $\mathbf{a}$ and $\left.1 \mathrm{C} \mathbf{b}, \mathrm{C}^{3}, \mathrm{C}_{5} \mathrm{H}_{4} \mathrm{~N}\right)$, $136.7\left(1 \mathrm{C}\right.$ of $\mathbf{a}$ and $1 \mathrm{C} \mathbf{b}, \mathrm{C}^{4}, \mathrm{C}_{5} \mathrm{H}_{4} \mathrm{~N}$ ), $149.2\left(1 \mathrm{C}\right.$ of $\mathbf{a}$ and $1 \mathrm{C} \mathbf{b}, \mathrm{C}^{6}$, $\left.\mathrm{C}_{5} \mathrm{H}_{4} \mathrm{~N}\right), 159.3\left(1 \mathrm{C}_{\mathrm{q}}\right.$ of $\mathbf{a}$ and $\left.1 \mathrm{C}_{\mathrm{q}} \mathbf{b}, \mathrm{C}^{2}, \mathrm{C}_{5} \mathrm{H}_{4} \mathrm{~N}\right), 237.6(2 \mathrm{C}$ of $\mathbf{a}$ and $2 \mathrm{C}$ b, CO). IR(ATR; $\left.\mathrm{cm}^{-1}\right)$ : 1927 vs $\left[\mathrm{v}_{\mathrm{a}}(\mathrm{CO})\right], 1838$ vs $\left[\mathrm{v}_{\mathrm{s}}(\mathrm{CO})\right]$. Single crystals of $\mathbf{7}$ suitable for $\mathrm{X}$-ray diffraction analysis were prepared by slow evaporation of hexane solution under inert atmosphere.

Synthesis of $\left[\left(\eta^{3}-\mathrm{C}_{3} \mathrm{H}_{5}\right)\left\{\eta^{5}-1-\left(\mathrm{C}_{5} \mathrm{H}_{4} \mathrm{NCH}_{2}\right) \mathrm{C}_{9} \mathrm{H}_{6}\right\} \mathrm{Mo}(\mathrm{CO})_{2}\right]$ (8). Method $\mathrm{A}$ : The reaction was carried out as described for compound 7 but with indene derivative 4 (2.07 g; $10 \mathrm{mmol})$. Yield: $2.63 \mathrm{~g}(6.6 \mathrm{mmol}, 66 \%)$. Method B: A solution of 4' $(2.05 \mathrm{~g}, 10 \mathrm{mmol})$ in $\mathrm{Et}_{2} \mathrm{O}(80 \mathrm{~mL})$ was treated with a solution of Super-Hydride in THF $(10 \mathrm{~mL}, 1.0 \mathrm{~mol} / \mathrm{L}, 10 \mathrm{mmol})$. The reaction mixture was stirred overnight. The white precipitate was decanted, washed with $\mathrm{Et}_{2} \mathrm{O}(3 \times 10 \mathrm{~mL})$ and vacuum dried. The white solid was dissolved in THF $(40 \mathrm{~mL})$, cooled to $-80^{\circ} \mathrm{C}$ and treated with a solution of $\left[\left(\eta^{3}-\mathrm{C}_{3} \mathrm{H}_{5}\right) \mathrm{Mo}(\mathrm{CO})_{2}(\mathrm{NCMe}){ }_{2} \mathrm{Cl}\right](3.1 \mathrm{~g}, 10 \mathrm{mmol})$ in THF (30 $\mathrm{mL}$ ) dropwise. The reaction mixture was stirred at room temperature overnight. The volatiles were vacuum evaporated and crude product was extracted with hexane $(3 \times 70 \mathrm{~mL})$ at $60^{\circ} \mathrm{C}$. The solvent was vacuum evaporated. The product was recrystallized from mixture hexane/ $\mathrm{Et}_{2} \mathrm{O}$ at $-80^{\circ} \mathrm{C}$ and vacuum dried. Yield: $2.48 \mathrm{~g}(6.2 \mathrm{mmol}, 62 \%)$. Yellow crystals. Mp: $64.7^{\circ} \mathrm{C}$. Anal. Calcd. for $\mathrm{C}_{20} \mathrm{H}_{17} \mathrm{MoNO}_{2}$ : C, 60.16; $\mathrm{H}, 4.29 ; \mathrm{N}, 3.01$. Found: C, 60.02; $\mathrm{H}, 4.39 ; \mathrm{N}, 2.85 .{ }^{1} \mathrm{H} \mathrm{NMR}\left(\mathrm{CDCl}_{3}, 400.13 \mathrm{MHz}, 3.8: 1\right.$ mixture of $\mathbf{8 a}\left(\right.$ exo- $\left.\mathrm{C}_{3} \mathrm{H}_{5}\right)$ and $\mathbf{8 b}\left(\right.$ endo- $\left.\left.\mathrm{C}_{3} \mathrm{H}_{5}\right)\right): \delta=-0.88\left(\mathrm{~d},{ }^{3} \mathrm{~J}\left({ }^{1} \mathrm{H}^{1}{ }^{1} \mathrm{H}\right)=\right.$ $10.9 \mathrm{~Hz}, 1 \mathrm{H}$ of $\left.\mathbf{b}, \mathrm{H}^{\text {anti }}, \mathrm{C}_{3} \mathrm{H}_{5}\right),-0.72\left(\mathrm{~d},{ }^{3} \mathrm{~J}\left({ }^{1} \mathrm{H},{ }^{1} \mathrm{H}\right)=10.7 \mathrm{~Hz}, 1 \mathrm{H}\right.$ of $\mathbf{b}$, $\left.\mathrm{H}^{\text {anti }}, \mathrm{C}_{3} \mathrm{H}_{5}\right), 0.22\left(\mathrm{~m}, 1 \mathrm{H}\right.$ of $\left.\mathbf{a}, \mathrm{H}^{\text {meso }}, \mathrm{C}_{3} \mathrm{H}_{5}\right), 0.86\left(\mathrm{~d},{ }^{3} \mathrm{~J}\left({ }^{1} \mathrm{H},{ }^{1} \mathrm{H}\right)=11.1 \mathrm{~Hz}\right.$, $1 \mathrm{H}$ of $\left.\mathbf{a}, \mathrm{H}^{\text {anti }}, \mathrm{C}_{3} \mathrm{H}_{5}\right), 0.96\left(\mathrm{~d},{ }^{3} \mathrm{~J}\left({ }^{1} \mathrm{H},{ }^{1} \mathrm{H}\right)=11.2 \mathrm{~Hz}, 1 \mathrm{H}\right.$ of $\left.\mathbf{a}, \mathrm{H}^{\text {anti }}, \mathrm{C}_{3} \mathrm{H}_{5}\right)$, $2.21\left(\mathrm{~d},{ }^{3} \mathrm{~J}\left({ }^{1} \mathrm{H}^{1}{ }^{1} \mathrm{H}\right)=7.3 \mathrm{~Hz}, 1 \mathrm{H}\right.$ of $\left.\mathrm{a}, \mathrm{H}^{\mathrm{syn}}, \mathrm{C}_{3} \mathrm{H}_{5}\right), 2.28\left(\mathrm{~d},{ }^{3} \mathrm{~J}\left({ }^{1} \mathrm{H},{ }^{1} \mathrm{H}\right)=7.4\right.$ $\mathrm{Hz}, 1 \mathrm{H}$ of $\left.\mathbf{a}, \mathrm{H}^{\text {syn }}, \mathrm{C}_{3} \mathrm{H}_{5}\right), 3.44-3.28\left(\mathrm{~m}, 3 \mathrm{H}\right.$ of $\left.\mathbf{b}, \mathrm{H}^{\text {syn }}, \mathrm{H}^{\text {meso }}, \mathrm{C}_{3} \mathrm{H}_{5}\right), 4.35$ (ABq, $\Delta \delta_{A B}=0.06,{ }^{2} \mathrm{~J}\left({ }^{1} \mathrm{H},{ }^{1} \mathrm{H}\right)=15.5 \mathrm{~Hz}, 2 \mathrm{H}$ of a, $\left.\mathrm{CH}_{2}\right), 4.39\left(\mathrm{ABq}, \Delta \delta_{\mathrm{AB}}\right.$ $=0.24,{ }^{2} \mathrm{~J}\left({ }^{1} \mathrm{H},{ }^{1} \mathrm{H}\right)=15.5 \mathrm{~Hz}, 2 \mathrm{H}$ of $\left.\mathbf{b}, \mathrm{CH}_{2}\right), 5.73\left(\mathrm{~d},{ }^{3} \mathrm{~J}\left({ }^{1} \mathrm{H},{ }^{1} \mathrm{H}\right)=2.7 \mathrm{~Hz}\right.$, $1 \mathrm{H}$ of $\left.\mathbf{b}, \mathrm{H}^{2}, \mathrm{C}_{9} \mathrm{H}_{6}\right), 5.79\left(\mathrm{~d},{ }^{3} \mathrm{~J}\left({ }^{1} \mathrm{H},{ }^{1} \mathrm{H}\right)=2.7 \mathrm{~Hz}, 1 \mathrm{H}\right.$ of $\left.\mathbf{a}, \mathrm{H}^{2}, \mathrm{C}_{9} \mathrm{H}_{6}\right), 5.83$ $\left(\mathrm{d},{ }^{3} \mathrm{~J}\left({ }^{1} \mathrm{H},{ }^{1} \mathrm{H}\right)=2.7 \mathrm{~Hz}, 1 \mathrm{H}\right.$ of $\left.\mathbf{b}, \mathrm{H}^{3}, \mathrm{C}_{9} H_{6}\right), 5.89\left(\mathrm{~d},{ }^{3} \mathrm{~J}\left({ }^{1} \mathrm{H},{ }^{1} \mathrm{H}\right)=2.7 \mathrm{~Hz}, 1 \mathrm{H}\right.$ of $\left.\mathbf{a}, \mathrm{H}^{3}, \mathrm{C}_{9} \mathrm{H}_{6}\right), 6.88-7.28\left(\mathrm{~m}, 6 \mathrm{H}\right.$ of $\mathbf{a}$ and $6 \mathrm{H}$ of $\mathbf{b}, \mathrm{H}^{4-7}$ of $\mathrm{C}_{9} \mathrm{H}_{6}$ and $\mathrm{H}^{3,5}$ of $\left.\mathrm{C}_{5} \mathrm{H}_{4} \mathrm{~N}\right), 7.57\left(\mathrm{dd}-\mathrm{br},{ }^{3} \mathrm{~J}\left({ }^{1} \mathrm{H},{ }^{1} \mathrm{H}\right)=7.8 \mathrm{~Hz},{ }^{3} \mathrm{~J}\left({ }^{1} \mathrm{H},{ }^{1} \mathrm{H}\right)=7.6 \mathrm{~Hz}, 1 \mathrm{H}\right.$ of $\mathbf{a}$ and $1 \mathrm{H}$ of $\left.\mathbf{b}, \mathrm{H}^{4}, \mathrm{C}_{5} \mathrm{H}_{4} \mathrm{~N}\right), 8.50\left(\mathrm{~d}-\mathrm{br},{ }^{3} \mathrm{~J}\left({ }^{1} \mathrm{H},{ }^{1} \mathrm{H}\right)=4.6 \mathrm{~Hz}, 1 \mathrm{H}\right.$ of $\mathbf{a}$ and $1 \mathrm{H}$ of $\left.\mathbf{b}, \mathrm{H}^{6}, \mathrm{C}_{5} \mathrm{H}_{4} \mathrm{~N}\right)$. IR(ATR; $\left.\mathrm{cm}^{-1}\right)$ : 1933 vs $\left[\mathrm{v}_{\mathrm{a}}(\mathrm{CO})\right], 1854$ vs $\left[\mathrm{v}_{\mathrm{s}}(\mathrm{CO})\right]$.
When the reaction was carried out with 4-D, 8-[D] was obtained, for which the signals at 5.83 and $5.89 \mathrm{ppm}$ in the ${ }^{1} \mathrm{H}$ NMR spectrum decreased in intensity ( $35 \%$ of initial intensity) and those at 5.73 and $5.79 \mathrm{ppm}$ were seen as a broadened singlet.

Synthesis of $\left[\left(\eta^{3}-\mathrm{C}_{3} \mathrm{H}_{5}\right)\left\{\eta^{5}-1,3-\left(\mathrm{C}_{5} \mathrm{H}_{4} \mathrm{NCH}_{2}\right)_{2} \mathrm{C}_{9} \mathrm{H}_{5}\right\} \mathrm{Mo}(\mathrm{CO})_{2}\right]$ (9). The reaction was carried out as described for compound 7 but with indene derivative 5 (2.97 g; $10 \mathrm{mmol})$. Yield: $1.14 \mathrm{~g}(3.2 \mathrm{mmol}, 32 \%)$. Yellow crystals. Mp: $133{ }^{\circ} \mathrm{C}$. Anal. Calcd. for $\mathrm{C}_{26} \mathrm{H}_{22} \mathrm{MoN}_{2} \mathrm{O}_{2}$ : C, 63.68; $\mathrm{H}, 4.52$ $\mathrm{N}, 5.71$. Found: $\mathrm{C}, 63.73 ; \mathrm{H}, 4.59 ; \mathrm{N}, 5.59 .{ }^{1} \mathrm{H} \mathrm{NMR}\left(\mathrm{CDCl}_{3}, 400.13 \mathrm{MHz}\right.$, $3.5: 1$ mixture of $9 \mathbf{a}\left(\right.$ exo- $\left.\mathrm{C}_{3} \mathrm{H}_{5}\right)$ and $9 \mathbf{b}\left(\right.$ endo- $\left.\left.\mathrm{C}_{3} \mathrm{H}_{5}\right)\right): \delta=-0,77$ $\left(\mathrm{d},{ }^{3} \mathrm{~J}\left({ }^{1} \mathrm{H},{ }^{1} \mathrm{H}\right)=10.6 \mathrm{~Hz}, 2 \mathrm{H}\right.$ of $\left.\mathbf{b}, \mathrm{H}^{\text {anti }}, \mathrm{C}_{3} \mathrm{H}_{5}\right), 0.51\left(\mathrm{tt},{ }^{3} \mathrm{~J}\left({ }^{1} \mathrm{H},{ }^{1} \mathrm{H}\right)=11.1\right.$ $\mathrm{Hz},{ }^{3} \mathrm{~J}\left({ }^{1} \mathrm{H},{ }^{1} \mathrm{H}\right)=7.3 \mathrm{~Hz}, 1 \mathrm{H}$ of $\left.\mathbf{a}, \mathrm{H}^{\text {meso }}, \mathrm{C}_{3} \mathrm{H}_{5}\right), 0.88\left(\mathrm{~d},{ }^{3} \mathrm{~J}\left({ }^{1} \mathrm{H},{ }^{1} \mathrm{H}\right)=11.1\right.$ $\mathrm{Hz}, 2 \mathrm{H}$ of $\left.\mathbf{a}, \mathrm{H}^{\text {anti }}, \mathrm{C}_{3} \mathrm{H}_{5}\right), 2.16\left(\mathrm{~d},{ }^{3} \mathrm{~J}\left({ }^{1} \mathrm{H},{ }^{1} \mathrm{H}\right)=7.3 \mathrm{~Hz}, 2 \mathrm{H}\right.$ of $\mathbf{a}, \mathrm{H}^{\text {syn }}$, $\left.\mathrm{C}_{3} H_{5}\right), 3.23-3.43\left(\mathrm{~m}, 3 \mathrm{H}\right.$ of $\left.\mathbf{b}, \mathrm{H}^{\text {syn }}, \mathrm{H}^{\text {meso }}, \mathrm{C}_{3} H_{5}\right), 4.31\left(\mathrm{ABq}, \Delta \delta_{\mathrm{AB}}=\right.$ $0.07,{ }^{2} \mathrm{~J}\left({ }^{1} \mathrm{H},{ }^{1} \mathrm{H}\right)=15.5 \mathrm{~Hz}, 2 \mathrm{H}$ of $\left.\mathbf{a}, \mathrm{CH}_{2}\right), 4.35\left(\mathrm{ABq}, \Delta \delta_{\mathrm{AB}}=\right.$ $0.19,{ }^{2} \mathrm{~J}\left({ }^{1} \mathrm{H},{ }^{1} \mathrm{H}\right)=15.5 \mathrm{~Hz}, 2 \mathrm{H}$ of $\left.\mathbf{b}, \mathrm{CH}_{2}\right), 5.93\left(\mathrm{~s}, 1 \mathrm{H}\right.$ of $\left.\mathbf{b}, \mathrm{H}^{2}, \mathrm{C}_{9} \mathrm{H}_{5}\right)$, $5.97\left(\mathrm{~s}, 1 \mathrm{H}\right.$ of $\left.\mathbf{a}, \mathrm{H}^{2}, \mathrm{C}_{9} \mathrm{H}_{5}\right), 6.93\left(\mathrm{dd},{ }^{3} \mathrm{~J}\left({ }^{1} \mathrm{H}^{1},{ }^{1} \mathrm{H}\right)=6.5 \mathrm{~Hz},{ }^{4} \mathrm{~J}\left({ }^{1} \mathrm{H},{ }^{1} \mathrm{H}\right)=3.1\right.$ $\mathrm{Hz}, 2 \mathrm{H}$ of b, $\left.\mathrm{H}^{4-7}, \mathrm{C}_{9} \mathrm{H}_{5}\right), 7.00\left(\mathrm{dd},{ }^{3} \mathrm{~J}\left({ }^{1} \mathrm{H},{ }^{1} \mathrm{H}\right)=6.5 \mathrm{~Hz},{ }^{4} \mathrm{~J}\left({ }^{1} \mathrm{H},{ }^{1} \mathrm{H}\right)=3.1 \mathrm{~Hz}\right.$ $2 \mathrm{H}$ of $\left.\mathbf{a}, \mathrm{H}^{4-7}, \mathrm{C}_{9} \mathrm{H}_{5}\right), 7.09-7.22\left(\mathrm{~m}, 6 \mathrm{H}\right.$ of $\mathbf{a}$ and $6 \mathrm{H}$ of $\mathbf{b}, \mathrm{H}^{4-7}$ of $\mathrm{C}_{9} \mathrm{H}_{5}$ and $\mathrm{H}^{3,5}$ of $\left.\mathrm{C}_{5} \mathrm{H}_{4} \mathrm{~N}\right), 7.56\left(\mathrm{~m}, 2 \mathrm{H}\right.$ of $\mathbf{a}$ and $2 \mathrm{H}$ of $\left.\mathbf{b}, \mathrm{H}^{4}, \mathrm{C}_{5} \mathrm{H}_{4} \mathrm{~N}\right), 8.50(\mathrm{~m}$, $2 \mathrm{H}$ of $\mathbf{a}$ and $2 \mathrm{H}$ of $\left.\mathbf{b}, \mathrm{H}^{6}, \mathrm{C}_{5} \mathrm{H}_{4} \mathrm{~N}\right)$. IR(ATR; $\left.\mathrm{cm}^{-1}\right): 1934$ vs [ $\left.\mathrm{v}_{\mathrm{a}}(\mathrm{CO})\right], 1853$ vs $\left[\mathrm{v}_{\mathrm{s}}(\mathrm{CO})\right]$. Raman $\left(\mathrm{cm}^{-1}\right)$ : 1919(3) $\left[\mathrm{v}_{\mathrm{a}}(\mathrm{CO})\right], 1838(10)\left[\mathrm{v}_{\mathrm{s}}(\mathrm{CO})\right]$. Single crystals of 9 suitable for $\mathrm{X}$-ray diffraction analysis were prepared by sublimation in vacuum-sealed $(1 \mathrm{~Pa})$ ampule at $110^{\circ} \mathrm{C}$.

$\left[\left(\eta^{5}-\mathrm{C}_{5} \mathrm{H}_{4} \mathrm{NHCH}_{2} \mathrm{C}_{5} \mathrm{H}_{4}\right) \mathrm{Mo}(\mathrm{CO})_{2}(\mathrm{NCMe})_{2}\right]\left[\mathrm{BF}_{4}\right]_{2} \quad(10)$. A solution of $7(0.7 \mathrm{~g}, 2 \mathrm{mmol})$ in $\mathrm{MeCN}(5 \mathrm{~mL})$ was cooled to $0^{\circ} \mathrm{C}$ and treated with $\mathrm{HBF}_{4} \cdot \mathrm{Et}_{2} \mathrm{O}(550 \mu \mathrm{L}, 4 \mathrm{mmol})$ dropwise. The reaction mixture was stirred at room temperature overnight. The volatiles were vacuum evaporated. Crude product was washed with $\mathrm{Et}_{2} \mathrm{O}(2 \times 5 \mathrm{~mL})$, recrystallized from the mixture $\mathrm{MeCN} / \mathrm{Et}_{2} \mathrm{O}$ and vacuum dried. Yield $0.49 \mathrm{~g}(0.86 \mathrm{mmol}, 43 \%)$ Red crystals. Mp: $137^{\circ} \mathrm{C}$ (dec). Anal. Calcd. for $\mathrm{C}_{17} \mathrm{H}_{17} \mathrm{~B}_{2} \mathrm{~F}_{8} \mathrm{MoN}_{3} \mathrm{O}_{2}$ : C 36.15; H, 3.03; N, 7.44. Found: C, 36.25; H, 3.16; N, 7.29. ${ }^{1} \mathrm{H}$ NMR $\left(\mathrm{CD}_{3} \mathrm{CN}, 400.13 \mathrm{MHz}\right): \delta=2.49\left(\mathrm{~s}, 6 \mathrm{H}, \mathrm{NCCH}_{3}\right), 4.06\left(\mathrm{~s}, 2 \mathrm{H}, \mathrm{CH}_{2}\right), 5.66$ (dd, $\left.{ }^{3} \mathrm{~J}\left({ }^{1} \mathrm{H},{ }^{1} \mathrm{H}\right)=2.2 \mathrm{~Hz},{ }^{4} \mathrm{~J}\left({ }^{1} \mathrm{H},{ }^{1} \mathrm{H}\right)=2.1 \mathrm{~Hz}, 2 \mathrm{H}, \mathrm{C}_{5} \mathrm{H}_{4}\right), 6.96$ (dd, $\left.{ }^{3} \mathrm{~J}\left({ }^{1} \mathrm{H},{ }^{1} \mathrm{H}\right)=2.2 \mathrm{~Hz},{ }^{4} \mathrm{~J}\left({ }^{1} \mathrm{H},{ }^{1} \mathrm{H}\right)=2.1 \mathrm{~Hz}, 2 \mathrm{H}, \mathrm{C}_{5} \mathrm{H}_{4}\right), 7.94-7.99(\mathrm{~m}, 2 \mathrm{H}$, $\left.\mathrm{H}^{3,5}, \mathrm{C}_{5} \mathrm{H}_{4} \mathrm{NH}\right), \quad 8.56$ (ddd, ${ }^{3} \mathrm{~J}\left({ }^{1} \mathrm{H},{ }^{1} \mathrm{H}\right)=8.0 \mathrm{~Hz},{ }^{3} \mathrm{~J}\left({ }^{1} \mathrm{H},{ }^{1} \mathrm{H}\right)=8.0$ $\left.\mathrm{Hz},{ }^{4} \mathrm{~J}\left({ }^{1} \mathrm{H},{ }^{1} \mathrm{H}\right)=1.0 \mathrm{~Hz}, 1 \mathrm{H}, \mathrm{H}^{4}, \mathrm{C}_{5} \mathrm{H}_{4} \mathrm{NH}\right), 8.65\left(\mathrm{t}-\mathrm{br},{ }^{3} \mathrm{~J}\left({ }^{1} \mathrm{H},{ }^{1} \mathrm{H}\right)=4.8 \mathrm{~Hz}\right.$ $1 \mathrm{H}, \mathrm{H}^{6}, \mathrm{C}_{5} \mathrm{H}_{4} \mathrm{NH}$ ), 13.2 (s-br, $\left.1 \mathrm{H}, \mathrm{C}_{5} \mathrm{H}_{4} \mathrm{NH}\right)$. IR (ATR; $\mathrm{cm}^{-1}$ ): 2324 vs $\left[\mathrm{v}_{\mathrm{a}}(\mathrm{CN})\right], 2296$ vs [ $\left.\mathrm{v}_{\mathrm{s}}(\mathrm{CN})\right], 1981$ vs [ $\left.\mathrm{v}_{\mathrm{a}}(\mathrm{CO})\right], 1905$ vs [ $\left.\mathrm{v}_{\mathrm{s}}(\mathrm{CO})\right], 1026$ vsbr [v(BF)]. Raman $\left(\mathrm{cm}^{-1}\right)$ : 2323(5) $\left[\mathrm{v}_{\mathrm{a}}(\mathrm{CN})\right], 2289(10)\left[\mathrm{v}_{\mathrm{s}}(\mathrm{CN})\right], 1984(4)$ $\left[\mathrm{v}_{\mathrm{a}}(\mathrm{CO})\right], 1917(8)\left[\mathrm{v}_{\mathrm{s}}(\mathrm{CO})\right]$. Single crystals of 10 suitable for X-ray diffraction analysis were prepared by diffusion of hexane into saturated solution of 10 in $\mathrm{CH}_{2} \mathrm{Cl}_{2}$.

[( $\left.\eta^{5}: \mathrm{KN}-\mathrm{C}_{5} \mathrm{H}_{4} \mathrm{NCH}_{2} \mathrm{C}_{5} \mathrm{H}_{4}\right) \mathrm{Mo}(\mathrm{CO})_{2}(\mathrm{NCMe})\left[\mathrm{BF}_{4}\right]$ (11). A solution of 7 $(0.7 \mathrm{~g}, 2 \mathrm{mmol})$ in the mixture of $\mathrm{CH}_{2} \mathrm{Cl}_{2}(5 \mathrm{~mL})$ and $\mathrm{MeCN}(105 \mu \mathrm{L}$ $2 \mathrm{mmol}$ ) was cooled to $0^{\circ} \mathrm{C}$ and treated with $\mathrm{HBF}_{4} \cdot \mathrm{Et}_{2} \mathrm{O}(225 \mu \mathrm{L}, 2 \mathrm{mmol})$ dropwise. The reaction mixture was stirred at room temperature overnight. The volatiles were vacuum evaporated. The remaining solid was dissolved in acetone $(10 \mathrm{~mL})$ and stirred overnight. The volatiles were vacuum evaporated, crude product was recrystallized from the mixture acetone/ $/ \mathrm{Et}_{2} \mathrm{O}$ and vacuum dried. Yield $0.64 \mathrm{~g}$ (1.48 mmol, 74\%). Purple crystals. Mp: $140{ }^{\circ} \mathrm{C}$ (dec). Anal. Calcd. for $\mathrm{C}_{15} \mathrm{H}_{13} \mathrm{BF}_{4} \mathrm{MoN}_{2} \mathrm{O}_{2}$ C, 41.31; H, 3.00; N, 6.42. Found: C, 41.16; H, 3.09; N, 6.50. Positive-ion MS (MeCN): $m / z=351(100 \%)[\mathrm{M}]^{+}, 310[\mathrm{M}-\mathrm{MeCN}]^{+} .{ }^{1} \mathrm{H}$ NMR (acetone- $\left.\mathrm{d}_{6}, 400.13 \mathrm{MHz}\right): \delta=2.66\left(\mathrm{~s}, 3 \mathrm{H}, \mathrm{NCCH}_{3}\right), 4.39\left(\mathrm{ABq}, \Delta \delta_{\mathrm{AB}}=\right.$ $\left.0.09 \mathrm{ppm},{ }^{2} \mathrm{~J}\left({ }^{1} \mathrm{H},{ }^{1} \mathrm{H}\right)=18.2 \mathrm{~Hz}, 2 \mathrm{H}, \mathrm{CH}_{2}\right), 5.19\left(\mathrm{ddd},{ }^{3} \mathrm{~J}\left({ }^{1} \mathrm{H},{ }^{1} \mathrm{H}\right)=2.6\right.$ $\left.\mathrm{Hz},{ }^{3} \mathrm{~J}\left({ }^{1} \mathrm{H},{ }^{1} \mathrm{H}\right)=2.6 \mathrm{~Hz},{ }^{4} \mathrm{~J}\left({ }^{1} \mathrm{H},{ }^{1} \mathrm{H}\right)=1.6 \mathrm{~Hz}, \quad 1 \mathrm{H}, \mathrm{C}_{5} \mathrm{H}_{4}\right), \quad 5.80$ (ddd, ${ }^{3} \mathrm{~J}\left({ }^{1} \mathrm{H},{ }^{1} \mathrm{H}\right)=2.7 \mathrm{~Hz},{ }^{3} \mathrm{~J}\left({ }^{1} \mathrm{H},{ }^{1} \mathrm{H}\right)=2.7 \mathrm{~Hz},{ }^{4} \mathrm{~J}\left({ }^{1} \mathrm{H},{ }^{1} \mathrm{H}\right)=1.6 \mathrm{~Hz}, 1 \mathrm{H}$, $\left.\mathrm{C}_{5} \mathrm{H}_{4}\right), 6.23$ (ddd, ${ }^{3} \mathrm{~J}\left({ }^{1} \mathrm{H},{ }^{1} \mathrm{H}\right)=2.7 \mathrm{~Hz},{ }^{4} \mathrm{~J}\left({ }^{1} \mathrm{H},{ }^{1} \mathrm{H}\right)=1.6 \mathrm{~Hz},{ }^{4} \mathrm{~J}\left({ }^{1} \mathrm{H},{ }^{1} \mathrm{H}\right)=1.6$ $\left.\mathrm{Hz}, \quad 1 \mathrm{H}, \quad \mathrm{C}_{5} \mathrm{H}_{4}\right), \quad 6.65$ (ddd, ${ }^{3} \mathrm{~J}\left({ }^{1} \mathrm{H}^{1},{ }^{1} \mathrm{H}\right)=2.8 \mathrm{~Hz},{ }^{4} \mathrm{~J}\left({ }^{1} \mathrm{H},{ }^{1} \mathrm{H}\right)=1.6$ $\left.\mathrm{Hz},{ }^{4} \mathrm{~J}\left({ }^{1} \mathrm{H},{ }^{1} \mathrm{H}\right)=1.6 \mathrm{~Hz}, 1 \mathrm{H}, \mathrm{C}_{5} \mathrm{H}_{4}\right), 7.38\left(\mathrm{dd},{ }^{3} \mathrm{~J}\left({ }^{1} \mathrm{H},{ }^{1} \mathrm{H}\right)=7.5 \mathrm{~Hz},{ }^{3} \mathrm{~J}\left({ }^{1} \mathrm{H},{ }^{1} \mathrm{H}\right)\right.$ $\left.=5.8 \mathrm{~Hz}, 1 \mathrm{H}, \mathrm{H}^{5}, \mathrm{C}_{5} \mathrm{H}_{4} \mathrm{~N}\right), 7.48\left(\mathrm{ddd},{ }^{3} \mathrm{~J}\left({ }^{1} \mathrm{H}^{1}{ }^{1} \mathrm{H}\right)=8.1 \mathrm{~Hz},{ }^{4} \mathrm{~J}\left({ }^{1} \mathrm{H},{ }^{1} \mathrm{H}\right)=1.5\right.$ $\left.\mathrm{Hz},{ }^{5} \mathrm{~J}\left({ }^{1} \mathrm{H},{ }^{1} \mathrm{H}\right)=0.8 \mathrm{~Hz}, 1 \mathrm{H}, \mathrm{H}^{3}, \mathrm{C}_{5} \mathrm{H}_{4} \mathrm{~N}\right), 7.95$, (ddd, ${ }^{3} \mathrm{~J}\left({ }^{1} \mathrm{H},{ }^{1} \mathrm{H}\right)=7.9 \mathrm{~Hz}$, $\left.{ }^{3} \mathrm{~J}\left({ }^{1} \mathrm{H},{ }^{1} \mathrm{H}\right)=7.9 \mathrm{~Hz},{ }^{4} \mathrm{~J}\left({ }^{1} \mathrm{H},{ }^{1} \mathrm{H}\right)=1.6 \mathrm{~Hz}, 1 \mathrm{H}, \mathrm{H}^{4}, \mathrm{C}_{5} \mathrm{H}_{4} \mathrm{~N}\right), 8.43$ (ddd, ${ }^{3} \mathrm{~J}\left({ }^{1} \mathrm{H},{ }^{1} \mathrm{H}\right)=5.9 \mathrm{~Hz},{ }^{4} \mathrm{~J}\left({ }^{1} \mathrm{H},{ }^{1} \mathrm{H}\right)=1.5 \mathrm{~Hz},{ }^{5} \mathrm{~J}\left({ }^{1} \mathrm{H},{ }^{1} \mathrm{H}\right)=0.7 \mathrm{~Hz}, 1 \mathrm{H}, \mathrm{H}^{6}$, $\mathrm{C}_{5} \mathrm{H}_{4} \mathrm{~N}$ ). ${ }^{13} \mathrm{C}\left\{{ }^{1} \mathrm{H}\right\}$ NMR (acetone- $\left.\mathrm{d}_{6}, 125.77 \mathrm{MHz}\right): \delta=36.3\left(1 \mathrm{C}, \mathrm{CH}_{2}\right.$ ), 
86.7, 87.8, 88.1, $104.0\left(4 \times 1 \mathrm{C}, \mathrm{C}_{5} \mathrm{H}_{4}\right), 124.7\left(1 \mathrm{C}, \mathrm{C}^{5}, \mathrm{C}_{5} \mathrm{H}_{4} \mathrm{~N}\right), 125.8$ $\left(1 \mathrm{C}, \mathrm{C}^{3}, \mathrm{C}_{5} \mathrm{H}_{4} \mathrm{~N}\right), 133.1\left(1 \mathrm{C}_{\mathrm{q}}, \mathrm{C}_{5} \mathrm{H}_{4}\right), 140.2\left(1 \mathrm{C}, \mathrm{C}^{4}, \mathrm{C}_{5} \mathrm{H}_{4} \mathrm{~N}\right), 155.6(1 \mathrm{C}$, $\left.\mathrm{C}^{6}, \mathrm{C}_{5} \mathrm{H}_{4} \mathrm{~N}\right), 175.8\left(1 \mathrm{C}_{\mathrm{q}}, \mathrm{C}^{2}, \mathrm{C}_{5} \mathrm{H}_{4} \mathrm{~N}\right), 248.8,251.8(2 \times 1 \mathrm{C}, \mathrm{CO}) . \mathrm{IR}$ $\left(A T R ; \mathrm{cm}^{-1}\right): 2285$ vs [v(CN)], 1982 vs [ $\left.\mathrm{v}_{\mathrm{a}}(\mathrm{CO})\right], 1866$ vs [ $\left.\mathrm{v}_{\mathrm{s}}(\mathrm{CO})\right], 1030$ vs-br [v(BF)]. Raman $\left(\mathrm{cm}^{-1}\right)$ : 2285(6) [v(CN)], 1982(7) [va $\left.(\mathrm{CO})\right], 1898(10)$ $\left[\mathrm{v}_{\mathrm{s}}(\mathrm{CO})\right]$. Single crystals of $\mathbf{1 1}$ suitable for $\mathrm{X}$-ray diffraction analysis were prepared by diffusion of hexane into saturated solution of 11 in $\mathrm{CH}_{2} \mathrm{Cl}_{2}$.

\section{Synthesis of $\left[\left(\eta^{5}: K N-\mathrm{C}_{5} \mathrm{H}_{4} \mathrm{NCH}_{2} \mathrm{C}_{5} \mathrm{H}_{4}\right) \mathrm{Mo}(\mathrm{CO})_{2}(\mathrm{py})\right]\left[\mathrm{BF} \mathrm{F}_{4}\right]$ (12). A} solution of $11(0.87 \mathrm{~g}, 2 \mathrm{mmol})$ in $\mathrm{CH}_{2} \mathrm{Cl}_{2}(5 \mathrm{~mL})$ was treated with pyridine ( $1 \mathrm{~mL}, 12 \mathrm{mmol}$ ) and stirred at room temperature overnight. The volatiles were vacuum evaporated. Crude product was washed with $\mathrm{Et}_{2} \mathrm{O}$ $(2 \times 10 \mathrm{~mL})$, recrystallized from the mixture $\mathrm{CH}_{2} \mathrm{Cl}_{2} / \mathrm{Et}_{2} \mathrm{O}$ and vacuum dried. Yield: $0.85 \mathrm{~g}(1.8 \mathrm{mmol}, 90 \%)$. Mp: $130{ }^{\circ} \mathrm{C}$ (dec). Red crystals. Anal. Calcd. for $\mathrm{C}_{18} \mathrm{H}_{15} \mathrm{BF}_{4} \mathrm{MoN}_{2} \mathrm{O}_{2}$ : C, 45.60; H, 3.19; N, 5.91. Found: C, 45.73; H, 3.22; N, 5.83. Positive-ion MS (MeCN): $\mathrm{m} / \mathrm{z}=389(100 \%)$ $[\mathrm{M}]^{+}, 351[\mathrm{M}-\mathrm{py}+\mathrm{MeCN}]^{+}, 310[\mathrm{M}-\mathrm{py}]^{+} .{ }^{1} \mathrm{H}$ NMR (acetone- $\mathrm{d}_{6}, 400.13$ $\left.\mathrm{MHz}): \delta=4.40,4.70\left(2 \times \mathrm{d},{ }^{2} \mathrm{~J}\left({ }^{1} \mathrm{H},{ }^{1} \mathrm{H}\right)=18.2 \mathrm{~Hz}\right), 2 \mathrm{H}, \mathrm{CH}_{2}\right), 5.35$ (ddd, ${ }^{3} \mathrm{~J}\left({ }^{1} \mathrm{H},{ }^{1} \mathrm{H}\right)=2.8 \mathrm{~Hz},{ }^{3} \mathrm{~J}\left({ }^{1} \mathrm{H},{ }^{1} \mathrm{H}\right)=2.8 \mathrm{~Hz},{ }^{4} \mathrm{~J}\left({ }^{1} \mathrm{H},{ }^{1} \mathrm{H}\right)=1.6 \mathrm{~Hz}, 1 \mathrm{H}$, $\left.\mathrm{C}_{5} \mathrm{H}_{4}\right), 5.89$ (ddd, ${ }^{3} \mathrm{~J}\left({ }^{1} \mathrm{H},{ }^{1} \mathrm{H}\right)=2.7 \mathrm{~Hz},{ }^{3} \mathrm{~J}\left({ }^{1} \mathrm{H},{ }^{1} \mathrm{H}\right)=2.7 \mathrm{~Hz},{ }^{4} \mathrm{~J}\left({ }^{1} \mathrm{H},{ }^{1} \mathrm{H}\right)=1.6$ $\left.\mathrm{Hz}, \quad 1 \mathrm{H}, \quad \mathrm{C}_{5} \mathrm{H}_{4}\right), 6.16\left(\mathrm{ddd},{ }^{3} \mathrm{~J}\left({ }^{1} \mathrm{H},{ }^{1} \mathrm{H}\right)=2.9 \mathrm{~Hz},{ }^{4} \mathrm{~J}\left({ }^{1} \mathrm{H},{ }^{1} \mathrm{H}\right)=1.6\right.$ $\left.\mathrm{Hz}, \quad{ }^{4} \mathrm{~J}\left({ }^{1} \mathrm{H},{ }^{1} \mathrm{H}\right)=1.6 \mathrm{~Hz}, \quad 1 \mathrm{H}, \quad \mathrm{C}_{5} \mathrm{H}_{4}\right), 6.77$ (ddd, ${ }^{3} \mathrm{~J}\left({ }^{1} \mathrm{H},{ }^{1} \mathrm{H}\right)=2.9$ $\left.\mathrm{Hz},{ }^{4} \mathrm{~J}\left({ }^{1} \mathrm{H},{ }^{1} \mathrm{H}\right)=1.6 \mathrm{~Hz},{ }^{4} \mathrm{~J}\left({ }^{1} \mathrm{H},{ }^{1} \mathrm{H}\right)=1.6 \mathrm{~Hz}, 1 \mathrm{H}, \mathrm{C}_{5} \mathrm{H}_{4}\right), 7.17\left(\mathrm{dd},{ }^{3} \mathrm{~J}\left({ }^{1} \mathrm{H},{ }^{1} \mathrm{H}\right)\right.$ $\left.=7.5 \mathrm{~Hz},{ }^{3} \mathrm{~J}\left({ }^{1} \mathrm{H},{ }_{1}^{1} \mathrm{H}\right)=6.0 \mathrm{~Hz}, 1 \mathrm{H}, \mathrm{H}^{5}, \mathrm{C}_{5} \mathrm{H}_{4} \mathrm{~N}\right), 7.53$, (ddd, ${ }^{3} \mathrm{~J}\left({ }^{1} \mathrm{H},{ }^{1} \mathrm{H}\right)=8.1$ $\left.\mathrm{Hz},{ }^{4} \mathrm{~J}\left({ }^{1} \mathrm{H},{ }^{1} \mathrm{H}\right)=1.5 \mathrm{~Hz},{ }^{5} \mathrm{~J}\left({ }^{1} \mathrm{H},{ }^{1} \mathrm{H}\right)=0.7 \mathrm{~Hz}, 1 \mathrm{H}, \mathrm{H}^{3}, \mathrm{C}_{5} \mathrm{H}_{4} \mathrm{~N}\right), 7.61(\mathrm{dt}$, $\left.{ }^{3} \mathrm{~J}\left({ }^{1} \mathrm{H},{ }^{1} \mathrm{H}\right)=7.7 \mathrm{~Hz},{ }^{3} \mathrm{~J}\left({ }^{1} \mathrm{H},{ }^{1} \mathrm{H}\right)=6.4 \mathrm{~Hz}, \quad 2 \mathrm{H}, \mathrm{H}^{3,5}, \mathrm{C}_{5} \mathrm{H}_{5} \mathrm{~N}\right), 7.87$ $\left(\mathrm{dd},{ }^{3} \mathrm{~J}\left({ }^{1} \mathrm{H},{ }^{1} \mathrm{H}\right)=7.8 \mathrm{~Hz},{ }^{3} \mathrm{~J}\left({ }^{1} \mathrm{H},{ }^{1} \mathrm{H}\right)=7.8 \mathrm{~Hz},{ }^{4} \mathrm{~J}\left({ }^{1} \mathrm{H},{ }^{1} \mathrm{H}\right)=1.6 \mathrm{~Hz}, 1 \mathrm{H}, \mathrm{H}^{4}\right.$, $\left.\mathrm{C}_{5} \mathrm{H}_{4} \mathrm{~N}\right), 8.07$, (tt, $\left.{ }^{3} \mathrm{~J}\left({ }^{1} \mathrm{H},{ }^{1} \mathrm{H}\right)=7.7 \mathrm{~Hz},{ }^{4} \mathrm{~J}\left({ }^{1} \mathrm{H},{ }^{1} \mathrm{H}\right)=1.5 \mathrm{~Hz}, 1 \mathrm{H}, \mathrm{H}^{4}, \mathrm{C}_{5} \mathrm{H}_{5} \mathrm{~N}\right)$ $8.19\left(\mathrm{~d},{ }^{3} \mathrm{~J}\left({ }^{1} \mathrm{H},{ }^{1} \mathrm{H}\right)=5.9 \mathrm{~Hz},{ }^{4} \mathrm{~J}\left({ }^{1} \mathrm{H},{ }^{1} \mathrm{H}\right)=1.5 \mathrm{~Hz},{ }^{5} \mathrm{~J}\left({ }^{1} \mathrm{H},{ }^{1} \mathrm{H}\right)=0.7 \mathrm{~Hz}, \quad 1 \mathrm{H}\right.$, $\left.\mathrm{H}^{6}, \mathrm{C}_{5} \mathrm{H}_{4} \mathrm{~N}\right), 9.11\left(\mathrm{dd},{ }^{3} \mathrm{~J}\left({ }^{1} \mathrm{H},{ }^{1} \mathrm{H}\right)=6.4 \mathrm{~Hz},{ }^{4} \mathrm{~J}\left({ }^{1} \mathrm{H},{ }^{1} \mathrm{H}\right)=1.5 \mathrm{~Hz}, 2 \mathrm{H}, \mathrm{H}^{2,6}\right.$, $\left.\mathrm{C}_{5} \mathrm{H}_{5} \mathrm{~N}\right) .{ }^{13} \mathrm{C}\left\{{ }^{1} \mathrm{H}\right\}$ NMR (acetone-d $6,125.77 \mathrm{MHz}$ ): $\delta=36.6\left(1 \mathrm{C}, \mathrm{CH}_{2}\right)$, 86.5, 87.1, 88.1, $106.8\left(4 \times 1 \mathrm{C}, \mathrm{C}_{5} \mathrm{H}_{4}\right), 124.7\left(1 \mathrm{C}, \mathrm{C}^{5}, \mathrm{C}_{5} \mathrm{H}_{4} \mathrm{~N}\right), 126.1$ $\left(1 \mathrm{C}, \mathrm{C}^{3}, \mathrm{C}_{5} \mathrm{H}_{4} \mathrm{~N}\right), 127.7\left(2 \mathrm{C}, \mathrm{C}^{3,5}, \mathrm{C}_{5} \mathrm{H}_{5} \mathrm{~N}\right), 133.3\left(1 \mathrm{C}_{\mathrm{q}}, \mathrm{C}_{5} \mathrm{H}_{4}\right), 140.3(1 \mathrm{C}$ $\left.\mathrm{C}^{4}, \mathrm{C}_{5} \mathrm{H}_{4} \mathrm{~N}\right), 140.5\left(1 \mathrm{C}, \mathrm{C}^{4}, \mathrm{C}_{5} \mathrm{H}_{5} \mathrm{~N}\right), 154.5\left(1 \mathrm{C}, \mathrm{C}^{6}, \mathrm{C}_{5} \mathrm{H}_{4} \mathrm{~N}\right), 158.3(2 \mathrm{C}$, $\left.\mathrm{C}^{2,6}, \mathrm{C}_{5} \mathrm{H}_{5} \mathrm{~N}\right), 175.4\left(1 \mathrm{C}_{\mathrm{q}}, \mathrm{C}^{2}, \mathrm{C}_{5} \mathrm{H}_{4} \mathrm{~N}\right), 249.5,250.1(2 \times 1 \mathrm{C}, \mathrm{CO}) . \mathrm{IR}$ $\left(A T R ; \mathrm{cm}^{-1}\right)$ : 1997 vs [ $\left.\mathrm{va}_{\mathrm{a}}(\mathrm{CO})\right], 1840$ vs [v $\left.(\mathrm{CO})\right], 1030$ vs-br [v(BF)]. Raman $\left(\mathrm{cm}^{-1}\right)$ : 2009(4) [ $\left.\mathrm{v}_{\mathrm{a}}(\mathrm{CO})\right]$, 2003(4) [ $\left.\mathrm{v}_{\mathrm{a}}(\mathrm{CO})\right], 1851(10)$ [ $\left.\mathrm{v}_{\mathrm{s}}(\mathrm{CO})\right]$. Single crystals of 12 suitable for $\mathrm{X}$-ray diffraction analysis were prepared by diffusion of hexane into saturated solution of 12 in $\mathrm{CH}_{2} \mathrm{Cl}_{2}$.

Synthesis of $\left[\left(\eta^{5}: \kappa N-\mathrm{C}_{5} \mathrm{H}_{4} \mathrm{NCH}_{2} \mathrm{C}_{5} \mathrm{H}_{4}\right) \mathrm{Mo}(\mathrm{CO})_{2} \mathrm{Cl}\right]$ (13). A solution of $11(0.87 \mathrm{~g}, 2 \mathrm{mmol})$ in acetone $(5 \mathrm{~mL})$ was treated with $\left[\mathrm{Me}_{4} \mathrm{~N}\right] \mathrm{Cl}(0.22 \mathrm{~g}$, $2 \mathrm{mmol}$ ) and stirred at room temperature overnight. The volatiles were vacuum evaporated and remaining solid was extracted with $\mathrm{CH}_{2} \mathrm{Cl}_{2}(7$ $\mathrm{mL}$ ). The white precipitate of $\left[\mathrm{Me}_{4} \mathrm{~N}\right]\left[\mathrm{BF}_{4}\right]$ was filtrated off and the volatiles of the filtrate were vacuum evaporated. The crude product was recrystallized from acetone/ $\mathrm{Et}_{2} \mathrm{O}$ and vacuum dried. Yield: $0.63 \mathrm{~g}(1.83$ mmol, 92\%). Purple crystals. Mp: $150{ }^{\circ} \mathrm{C}$ (dec). Anal. Calcd. for $\mathrm{C}_{13} \mathrm{H}_{10} \mathrm{ClMoNO}_{2}$ : C, 45.44; $\mathrm{H}, 2.93 ; \mathrm{N}, 4.07$. Found: $\mathrm{C}, 45.62 ; \mathrm{H}, 2.85 ; \mathrm{N}$ 3.94. ${ }^{1} \mathrm{H}$ NMR (acetone- $\left.\mathrm{d}^{6}, 400.13 \mathrm{MHz}\right): \delta=4.46\left(\mathrm{ABq}, \Delta \delta_{\mathrm{AB}}=0.05\right.$ ppm, $\left.{ }^{2} \mathrm{~J}\left({ }^{1} \mathrm{H},{ }^{1} \mathrm{H}\right)=18.0 \mathrm{~Hz}, 2 \mathrm{H}, \mathrm{CH}_{2}\right), 5.98\left(\mathrm{ddd},{ }^{3} \mathrm{~J}\left({ }^{1} \mathrm{H},{ }^{1} \mathrm{H}\right)=2.5\right.$ $\left.\mathrm{Hz},{ }^{3} \mathrm{~J}\left({ }^{1} \mathrm{H},{ }^{1} \mathrm{H}\right)=2.5 \mathrm{~Hz},{ }^{4} \mathrm{~J}\left({ }^{1} \mathrm{H},{ }^{1} \mathrm{H}\right)=1.6 \mathrm{~Hz}, \quad 1 \mathrm{H}, \mathrm{C}_{5} \mathrm{H}_{4}\right), \quad 5.62$ (ddd, ${ }^{3} \mathrm{~J}\left({ }^{1} \mathrm{H},{ }^{1} \mathrm{H}\right)=2.7 \mathrm{~Hz},{ }^{3} \mathrm{~J}\left({ }^{1} \mathrm{H},{ }^{1} \mathrm{H}\right)=2.7 \mathrm{~Hz},{ }^{4} \mathrm{~J}\left({ }^{1} \mathrm{H},{ }^{1} \mathrm{H}\right)=1.6 \mathrm{~Hz}, 1 \mathrm{H}$, $\left.\mathrm{C}_{5} \mathrm{H}_{4}\right), 6.01$ (ddd, ${ }^{3} \mathrm{~J}\left({ }^{1} \mathrm{H},{ }^{1} \mathrm{H}\right)=2.9 \mathrm{~Hz},{ }^{4} \mathrm{~J}\left({ }^{1} \mathrm{H},{ }^{1} \mathrm{H}\right)=1.7 \mathrm{~Hz},{ }^{4} \mathrm{~J}\left({ }^{1} \mathrm{H},{ }^{1} \mathrm{H}\right)=1.7$ $\left.\mathrm{Hz}, \quad 1 \mathrm{H}, \quad \mathrm{C}_{5} \mathrm{H}_{4}\right), \quad 6.03$ (ddd, ${ }^{3} \mathrm{~J}\left({ }^{1} \mathrm{H},{ }^{1} \mathrm{H}\right)=2.8 \mathrm{~Hz},{ }^{4} \mathrm{~J}\left({ }^{1} \mathrm{H},{ }^{1} \mathrm{H}\right)=1.7$ $\left.\mathrm{Hz},{ }^{4} \mathrm{~J}\left({ }^{1} \mathrm{H},{ }^{1} \mathrm{H}\right)=1.7 \mathrm{~Hz}, 1 \mathrm{H}, \mathrm{C}_{5} \mathrm{H}_{4}\right), 7.22\left(\mathrm{dd},{ }^{3} \mathrm{~J}\left({ }^{1} \mathrm{H},{ }^{1} \mathrm{H}\right)=7.6 \mathrm{~Hz},{ }^{3} \mathrm{~J}\left({ }^{1} \mathrm{H},{ }^{1} \mathrm{H}\right)\right.$ $\left.=5.7 \mathrm{~Hz}, 1 \mathrm{H}, \mathrm{H}^{5}, \mathrm{C}_{5} \mathrm{H}_{4} \mathrm{~N}\right), 7.31\left(\mathrm{~d},{ }^{3} \mathrm{~J}\left({ }^{1} \mathrm{H},{ }^{1} \mathrm{H}\right)=7.9 \mathrm{~Hz}, 1 \mathrm{H}, \mathrm{H}^{3}, \mathrm{C}_{5} \mathrm{H}_{4} \mathrm{~N}\right)$, $7.79\left(\mathrm{td},{ }^{3} \mathrm{~J}\left({ }^{1} \mathrm{H},{ }^{1} \mathrm{H}\right)=7.8 \mathrm{~Hz},{ }^{4} \mathrm{~J}\left({ }^{1} \mathrm{H},{ }^{1} \mathrm{H}\right)=1.7 \mathrm{~Hz}, 1 \mathrm{H}, \mathrm{H}^{4}, \mathrm{C}_{5} \mathrm{H}_{4} \mathrm{~N}\right), 8.34$ $\left(\mathrm{d},{ }^{3} \mathrm{~J}\left({ }^{1} \mathrm{H},{ }^{1} \mathrm{H}\right)=5.7 \mathrm{~Hz}, 1 \mathrm{H}, \mathrm{H}^{6}, \mathrm{C}_{5} \mathrm{H}_{4} \mathrm{~N}\right) \cdot{ }^{13} \mathrm{C}\left\{{ }^{1} \mathrm{H}\right\}$ NMR $\left(\mathrm{CD}_{3} \mathrm{CN}, 125.77\right.$ $\mathrm{MHz}): \delta=36.2\left(1 \mathrm{C}, \mathrm{CH}_{2}\right), 86.2,87.02,87.04,108.3\left(4 \times 1 \mathrm{C}, \mathrm{C}_{5} \mathrm{H}_{4}\right)$, $123.7\left(1 \mathrm{C}, \mathrm{C}^{5}, \mathrm{C}_{5} \mathrm{H}_{4} \mathrm{~N}\right), 124.6\left(1 \mathrm{C}, \mathrm{C}^{3}, \mathrm{C}_{5} \mathrm{H}_{4} \mathrm{~N}\right), 131.1\left(1 \mathrm{C}_{\mathrm{q}}, \mathrm{C}_{5} \mathrm{H}_{4}\right)$, $139.2\left(1 \mathrm{C}, \mathrm{C}^{4}, \mathrm{C}_{5} \mathrm{H}_{4} \mathrm{~N}\right), 156.7\left(1 \mathrm{C}, \mathrm{C}^{6}, \mathrm{C}_{5} \mathrm{H}_{4} \mathrm{~N}\right), 173.6\left(1 \mathrm{C}_{\mathrm{q}}, \mathrm{C}^{2}, \mathrm{C}_{5} \mathrm{H}_{4} \mathrm{~N}\right)$, 252.8, $264.3(2 \times 1 \mathrm{C}, \mathrm{CO})$. IR (ATR; $\left.\mathrm{cm}^{-1}\right): 1945$ vs [ $\left.\mathrm{v}_{\mathrm{a}}(\mathrm{CO})\right], 1827$ vs [ $\left.\mathrm{v}_{\mathrm{s}}(\mathrm{CO})\right]$. Raman $\left(\mathrm{cm}^{-1}\right)$ : 1950(8) $\left[\mathrm{v}_{\mathrm{a}}(\mathrm{CO})\right]$, 1846(10) [ $\left.\mathrm{v}_{\mathrm{s}}(\mathrm{CO})\right]$. Single crystals of 13 suitable for $\mathrm{X}$-ray diffraction analysis were prepared by diffusion of hexane into saturated solution of 13 in $\mathrm{CH}_{2} \mathrm{Cl}_{2}$.

Synthesis of $\left[\left\{\eta^{3}: K N-1-\left(\mathrm{C}_{5} \mathrm{H}_{4} \mathrm{NCH}_{2}\right) \mathrm{C}_{9} \mathrm{H}_{6}\right\} \mathrm{Mo}(\mathrm{CO})_{2}(\mathrm{NCMe})_{2}\right]\left[\mathrm{BF}{ }_{4}\right]$ (14). A solution of $8(0.8 \mathrm{~g}, 2 \mathrm{mmol})$ in the mixture of $\mathrm{CH}_{2} \mathrm{Cl}_{2}(5 \mathrm{~mL})$ and
MeCN $(208 \mu \mathrm{L}, 4 \mathrm{mmol})$ was cooled to $0^{\circ} \mathrm{C}$ and treated with $\mathrm{HBF}_{4} \cdot \mathrm{Et}_{2} \mathrm{O}$ $(275 \mu \mathrm{L}, 2 \mathrm{mmol})$ dropwise. The reaction mixture was stirred at room temperature overnight and volatiles were vacuum evaporated. The remaining solid was dissolved in acetone $(7 \mathrm{~mL})$, stirred at room temperature overnight and vacuum evaporated. This step was repeated with $\mathrm{MeCN}$. The obtained crude product was washed with $\mathrm{CH}_{2} \mathrm{Cl}_{2}(5 \mathrm{~mL})$ and recrystallized from $\mathrm{MeCN} / \mathrm{Et}_{2} \mathrm{O}$ and vacuum dried. Yield: 0.59 (1.12 mmol, 56\%). Mp: $138{ }^{\circ} \mathrm{C}$ (dec). Red crystals. Anal. Calcd. for $\mathrm{C}_{21} \mathrm{H}_{18} \mathrm{BF}_{4} \mathrm{MoN}_{3} \mathrm{O}_{2}: \mathrm{C}, 47.85 ; \mathrm{H}, 3.44 ; \mathrm{N}, 7.97$. Found: C, 47.61; $\mathrm{H}$, 3.42; N, 7.87. Positive-ion MS (MeCN): $m / z=414[\mathrm{M}-\mathrm{CO}]^{+}, 401(100 \%)$ $[\mathrm{M}-\mathrm{MeCN}]^{+}, 373\left[\mathrm{M}-\mathrm{MeCN}-\mathrm{CO}^{+}, 360[\mathrm{M}-2 \mathrm{MeCN}]^{+} .{ }^{1} \mathrm{H} \mathrm{NMR}\right.$ $\left(\mathrm{CD}_{3} \mathrm{CN}, 400.13 \mathrm{MHz}\right): \delta=4.03,4.27\left(2 \times \mathrm{d},{ }^{2} \mathrm{~J}\left({ }^{1} \mathrm{H},{ }^{1} \mathrm{H}\right)=19.8 \mathrm{~Hz}, 2 \mathrm{H}\right.$, $\left.\mathrm{CH}_{2}\right), 5.14\left(\mathrm{~d},{ }^{3} \mathrm{~J}\left({ }^{1} \mathrm{H},{ }_{1} \mathrm{H}\right)=3.9 \mathrm{~Hz}, 1 \mathrm{H}, \mathrm{H}^{3}, \mathrm{C}_{9} \mathrm{H}_{6}\right), 6.45-6.61\left(\mathrm{~m}, 4 \mathrm{H}, \mathrm{H}^{4-7}\right.$ $\left.\mathrm{C}_{9} \mathrm{H}_{6}\right), 6.83\left(\mathrm{~d},{ }^{3} \mathrm{~J}\left({ }^{1} \mathrm{H},{ }^{1} \mathrm{H}\right)=3.9 \mathrm{~Hz}, 1 \mathrm{H}, \mathrm{H}^{2}, \mathrm{C}_{9} \mathrm{H}_{6}\right), 7.33\left(\mathrm{dd},{ }^{3} \mathrm{~J}\left({ }^{1} \mathrm{H},{ }^{1} \mathrm{H}\right)=\right.$ $\left.7.6 \mathrm{~Hz},{ }^{3} \mathrm{~J}\left({ }^{1} \mathrm{H},{ }^{1} \mathrm{H}\right)=5.6 \mathrm{~Hz}, 1 \mathrm{H}, \mathrm{H}^{5}, \mathrm{C}_{5} \mathrm{H}_{4} \mathrm{~N}\right), 7.62\left(\mathrm{~d},{ }^{3} \mathrm{~J}\left({ }^{1} \mathrm{H},{ }^{1} \mathrm{H}\right)=7.8 \mathrm{~Hz}\right.$ $\left.1 \mathrm{H}, \mathrm{H}^{3}, \mathrm{C}_{5} \mathrm{H}_{4} \mathrm{~N}\right), 7.84\left(\mathrm{~d},{ }^{3} \mathrm{~J}\left({ }^{1} \mathrm{H},{ }^{1} \mathrm{H}\right)=5.6 \mathrm{~Hz}, 1 \mathrm{H}, \mathrm{H}^{6}, \mathrm{C}_{5} \mathrm{H}_{4} \mathrm{~N}\right), 7.93$ (ddd, ${ }^{3} \mathrm{~J}\left({ }^{1} \mathrm{H},{ }_{1}^{1} \mathrm{H}\right)=7.7 \mathrm{~Hz},{ }^{3} \mathrm{~J}\left({ }^{1} \mathrm{H},{ }^{1} \mathrm{H}\right)=7.7 \mathrm{~Hz},{ }^{4} \mathrm{~J}\left({ }^{1} \mathrm{H},{ }^{1} \mathrm{H}\right)=1.6 \mathrm{~Hz}, 1 \mathrm{H}, \mathrm{H}^{4}$ $\left.\mathrm{C}_{5} \mathrm{H}_{4} \mathrm{~N}\right) .{ }^{13} \mathrm{C}\left\{{ }^{1} \mathrm{H}\right\}$ NMR $\left(\mathrm{CD}_{3} \mathrm{CN}, 125.77 \mathrm{MHz}\right): \delta=35.8\left(1 \mathrm{C}, \mathrm{CH}_{2}\right), 73.1$ $\left(1 \mathrm{C}, \mathrm{C}^{3}, \mathrm{C}_{9} \mathrm{H}_{6}\right), 86.0\left(1 \mathrm{C}_{\mathrm{q}}, \mathrm{C}^{1}, \mathrm{C}_{9} \mathrm{H}_{6}\right), 98.8\left(1 \mathrm{C}, \mathrm{C}^{2}, \mathrm{C}_{9} \mathrm{H}_{6}\right), 116.1,117.2$ 124.8, $124.9\left(4 \times 1 \mathrm{C}, \mathrm{C}^{4-7} \mathrm{C}_{9} \mathrm{H}_{6}\right), 123.8\left(1 \mathrm{C}, \mathrm{C}^{5}, \mathrm{C}_{5} \mathrm{H}_{4} \mathrm{~N}\right), 124.5\left(1 \mathrm{C}, \mathrm{C}^{3}\right.$, $\left.\mathrm{C}_{5} \mathrm{H}_{4} \mathrm{~N}\right), 139.5\left(1 \mathrm{C}, \mathrm{C}^{4}, \mathrm{C}_{5} \mathrm{H}_{4} \mathrm{~N}\right), 146.0,147.6\left(2 \times 1 \mathrm{C}_{\mathrm{q}}, \mathrm{C}^{3 \mathrm{a}, 7 \mathrm{a}}, \mathrm{C}_{9} \mathrm{H}_{6}\right)$, $150.2\left(1 \mathrm{C}, \mathrm{C}^{6}, \mathrm{C}_{5} \mathrm{H}_{4} \mathrm{~N}\right), 161.8\left(1 \mathrm{C}_{\mathrm{q}}, \mathrm{C}^{2}, \mathrm{C}_{5} \mathrm{H}_{4} \mathrm{~N}\right), 221.1,221.4(2 \times$ $1 \mathrm{C}, \mathrm{CO})$. IR (ATR; $\left.\mathrm{cm}^{-1}\right): 2317$ vs $\left[\mathrm{V}_{\mathrm{a}}(\mathrm{CN})\right], 2284$ vs $\left[\mathrm{v}_{\mathrm{s}}(\mathrm{CN})\right], 1967$ vs [ $\left.\mathrm{v}_{\mathrm{a}}(\mathrm{CO})\right], 1904$ vs [ $\left.\mathrm{v}_{\mathrm{s}}(\mathrm{CO})\right], 1029 \mathrm{vs}-\mathrm{br}[\mathrm{v}(\mathrm{BF})]$. Raman $\left(\mathrm{cm}^{-1}\right):$ :2316(3) $\left[\mathrm{V}_{\mathrm{a}}(\mathrm{CN})\right], 2284(10)\left[\mathrm{v}_{\mathrm{s}}(\mathrm{CN})\right], 1988(2)\left[\mathrm{v}_{\mathrm{a}}(\mathrm{CO})\right], 1900(4)$ [ $\left.\mathrm{v}_{\mathrm{s}}(\mathrm{CO})\right]$. Single crystals of $14 \cdot \mathrm{CH}_{2} \mathrm{Cl}_{2}$ suitable for X-ray diffraction analysis were prepared by diffusion of $\mathrm{Et}_{2} \mathrm{O}$ into saturated solution of 14 in $\mathrm{CH}_{2} \mathrm{Cl}_{2}$. When the reaction was carried out with 8-[D], 14-[D] was obtained, for which the signal at $5.14 \mathrm{ppm}$ in the ${ }^{1} \mathrm{H}$ NMR spectrum decreased in intensity ( $35 \%$ of initial intensity) and that at $6.83 \mathrm{ppm}$ was seen as a broadened singlet.

Synthesis of $\left[\left\{\eta^{3}: K N-1-\left(\mathrm{C}_{5} \mathrm{H}_{4} \mathrm{NCH}_{2}\right) \mathrm{C}_{9} \mathrm{H}_{6}\right\} \mathrm{Mo}(\mathrm{CO})_{2}(\right.$ phen $\left.)\right]\left[B \mathrm{BF}_{4}\right]$ (15). A solution of $14(1.05,2 \mathrm{mmol})$ in $\mathrm{MeCN}(5 \mathrm{~mL})$ was treated with 1,10 phenanthroline $(0.36 \mathrm{~g}, 2 \mathrm{mmol})$. The reaction mixture was stirred at room temperature overnight. The volatiles were vacuum evaporated. Crude product was washed with $\mathrm{CH}_{2} \mathrm{Cl}_{2}(3 \times 5 \mathrm{~mL})$, recrystallized from $\mathrm{MeCN} / \mathrm{Et}_{2} \mathrm{O}$ and vacuum dried. Yield: $1.11 \mathrm{~g}$ (1.78 mmol, 89\%). Brown crystals. $\mathrm{Mp}: 155^{\circ} \mathrm{C}$ (dec). Anal. Calcd. for $\mathrm{C}_{29} \mathrm{H}_{20} \mathrm{BF}_{4} \mathrm{MoN}_{3} \mathrm{O}_{2}$ : C, 55.71; H, 3.22; N, 6.72. Found: C, 55.55; H, 3.09; N, 6.64. Positive-ion MS (MeCN): $m / z=540(100 \%)[\mathrm{M}]^{+}, 512\left[\mathrm{M}-\mathrm{CO}^{+}, 484\left[\mathrm{M}-2 \mathrm{CO}^{+} .{ }^{1} \mathrm{H}\right.\right.$ NMR (acetone- $\left.\mathrm{d}_{6}, 400.13 \mathrm{MHz}\right): \delta=4.37,4.66\left(2 \times \mathrm{d},{ }^{2} \mathrm{~J}\left({ }^{1} \mathrm{H},{ }^{1} \mathrm{H}\right)=19.8\right.$ $\left.\mathrm{Hz}, 2 \mathrm{H}, \mathrm{CH}_{2}\right), 5.51\left(\mathrm{~d},{ }^{3} \mathrm{~J}\left({ }^{1} \mathrm{H}^{1}{ }^{1} \mathrm{H}\right)=3.9 \mathrm{~Hz}, 1 \mathrm{H}, \mathrm{H}^{3}, \mathrm{C}_{9} \mathrm{H}_{6}\right), 5.99$ (ddd, ${ }^{3} \mathrm{~J}\left({ }^{1} \mathrm{H},{ }^{1} \mathrm{H}\right)=5.2 \mathrm{~Hz},{ }^{4} \mathrm{~J}\left({ }^{1} \mathrm{H},{ }^{1} \mathrm{H}\right)=1.1 \mathrm{~Hz},{ }^{4} \mathrm{~J}\left({ }^{1} \mathrm{H},{ }^{1} \mathrm{H}\right)=1.1 \mathrm{~Hz}, 1 \mathrm{H}, \mathrm{H}^{6}$, $\left.\mathrm{C}_{5} \mathrm{H}_{4} \mathrm{~N}\right), 6.51-6.70\left(\mathrm{~m}, 2 \mathrm{H}\right.$ of $\mathrm{C}_{9} \mathrm{H}_{6}\left(\mathrm{H}^{4-7}\right)$ and $2 \mathrm{H}$ of $\left.\mathrm{C}_{5} \mathrm{H}_{4} \mathrm{~N}\left(\mathrm{H}^{4,5}\right)\right), 6.71$ (dd, $\left.{ }^{3} \mathrm{~J}\left({ }^{1} \mathrm{H},{ }^{1} \mathrm{H}\right)=7.2 \mathrm{~Hz},{ }^{4} \mathrm{~J}\left({ }^{1} \mathrm{H},{ }^{1} \mathrm{H}\right)=0.7 \mathrm{~Hz}, \mathrm{H}^{3}, \mathrm{C}_{5} \mathrm{H}_{4} \mathrm{~N}\right), 7.40$ $\left(\mathrm{d},{ }^{3} \mathrm{~J}\left({ }^{1} \mathrm{H},{ }^{1} \mathrm{H}\right)=3.9 \mathrm{~Hz}, 1 \mathrm{H}, \mathrm{H}^{2}, \mathrm{C}_{9} H_{6}\right), 7.81\left(\mathrm{~m}, 2 \mathrm{H}, \mathrm{H}^{4-7}, \mathrm{C}_{9} H_{6}\right), 8.14$ $\left(\right.$ dd, $\left.{ }^{3} \mathrm{~J}\left({ }^{1} \mathrm{H},{ }^{1} \mathrm{H}\right)=8.2 \mathrm{~Hz},{ }^{3} \mathrm{~J}\left({ }^{1} \mathrm{H},{ }^{1} \mathrm{H}\right)=5.2 \mathrm{~Hz}, 1 \mathrm{H}, \mathrm{H}^{3 / 8}, \mathrm{C}_{12} \mathrm{H}_{8} \mathrm{~N}_{2}\right), 8.39$ $\left(\mathrm{dd},{ }^{3} \mathrm{~J}\left({ }^{1} \mathrm{H},{ }^{1} \mathrm{H}\right)=8.3 \mathrm{~Hz},{ }^{3} \mathrm{~J}\left({ }^{1} \mathrm{H}^{1}{ }^{1} \mathrm{H}\right)=5.2 \mathrm{~Hz}, 1 \mathrm{H}, \mathrm{H}^{3 / 8}, \mathrm{C}_{12} \mathrm{H}_{8} \mathrm{~N}_{2}\right), 8.43$ (ABq, $\Delta \delta_{A B}=0.04 \mathrm{ppm},{ }^{3} \mathrm{~J}\left({ }^{1} \mathrm{H},{ }^{1} \mathrm{H}\right)=8.7 \mathrm{~Hz}, 2 \mathrm{H}, \mathrm{H}^{5,6}, \mathrm{C}_{12} \mathrm{H}_{8} \mathrm{~N}_{2}$ ), 8.93 $\left(\mathrm{dd},{ }^{3} \mathrm{~J}\left({ }^{1} \mathrm{H},{ }_{1}^{1} \mathrm{H}\right)=8.2 \mathrm{~Hz},{ }^{4} \mathrm{~J}\left({ }^{1} \mathrm{H},{ }^{1} \mathrm{H}\right)=1.3 \mathrm{~Hz}, 1 \mathrm{H}, \mathrm{H}^{4 / 7}, \mathrm{C}_{12} \mathrm{H}_{8} \mathrm{~N}_{2}\right), 9.11$ (dd, ${ }^{3} \mathrm{~J}\left({ }^{1} \mathrm{H},{ }^{1} \mathrm{H}\right)=8.3 \mathrm{~Hz},{ }^{4} \mathrm{~J}\left({ }^{1} \mathrm{H}^{1}{ }^{1} \mathrm{H}\right)=1.4 \mathrm{~Hz}, 1 \mathrm{H}, \mathrm{H}^{4 / 7}, \mathrm{C}_{12} \mathrm{H}_{8} \mathrm{~N}_{2}$ ), 9.51 (dd, $\left.{ }^{3} \mathrm{~J}\left({ }^{1} \mathrm{H},{ }^{1} \mathrm{H}\right)=5.2 \mathrm{~Hz},{ }^{4} \mathrm{~J}\left({ }^{1} \mathrm{H},{ }^{1} \mathrm{H}\right)=1.3 \mathrm{~Hz}, 1 \mathrm{H}, \mathrm{H}^{2 / 9}, \mathrm{C}_{12} \mathrm{H}_{8} \mathrm{~N}_{2}\right), 10.1$ $\left(\mathrm{dd},{ }^{3} \mathrm{~J}\left({ }^{1} \mathrm{H},{ }^{1} \mathrm{H}\right)=5.2 \mathrm{~Hz},{ }^{4} \mathrm{~J}\left({ }^{1} \mathrm{H},{ }^{1} \mathrm{H}\right)=1.3 \mathrm{~Hz}, 1 \mathrm{H}, \mathrm{H}^{2 / 9}, \mathrm{C}_{12} \mathrm{H}_{8} \mathrm{~N}_{2}\right) \cdot{ }^{13} \mathrm{C}\left\{{ }^{1} \mathrm{H}\right\}$ NMR $\left(\mathrm{CD}_{3} \mathrm{CN}, 125.77 \mathrm{MHz}\right): \delta=36.8\left(1 \mathrm{C}, \mathrm{CH}_{2}\right), 73.0\left(1 \mathrm{C}, \mathrm{C}^{3}, \mathrm{C}_{9} \mathrm{H}_{6}\right)$, $86.5\left(1 \mathrm{C}_{\mathrm{q}}, \mathrm{C}^{1}, \mathrm{C}_{9} \mathrm{H}_{6}\right), \quad 98.6\left(1 \mathrm{C}, \mathrm{C}^{2}, \mathrm{C}_{9} \mathrm{H}_{6}\right), 116.6\left(1 \mathrm{C}, \mathrm{C}^{3}, \mathrm{C}_{4} \mathrm{H}_{5} \mathrm{~N}\right)$, $118.4,124.8,125.7,125.9,126.0\left(5 \times 1 \mathrm{C}, \mathrm{C}_{4} \mathrm{H}_{5} \mathrm{~N}\left(\mathrm{C}^{4,5}\right), \mathrm{C}_{9} \mathrm{H}_{6}\left(\mathrm{C}^{4-7}\right)\right.$ $126.5\left(1 \mathrm{C}, \mathrm{C}^{3 / 8}, \mathrm{C}_{12} \mathrm{H}_{8} \mathrm{~N}_{2}\right), 127.5\left(1 \mathrm{C}, \mathrm{C}^{3 / 8}, \mathrm{C}_{12} \mathrm{H}_{8} \mathrm{~N}_{2}\right), 128.9\left(1 \mathrm{C}, \mathrm{C}^{5 / 6}\right.$, $\left.\mathrm{C}_{12} \mathrm{H}_{8} \mathrm{~N}_{2}\right), 129.4\left(1 \mathrm{C}, \mathrm{C}^{5 / 6}, \mathrm{C}_{12} \mathrm{H}_{8} \mathrm{~N}_{2}\right), 132.0,132.2,142.0,144.7(4 \times$ $\left.1 \mathrm{C}_{\mathrm{q}}, \mathrm{C}_{12} \mathrm{H}_{8} \mathrm{~N}_{2}\right), 140.2\left(1 \mathrm{C}, \mathrm{C}^{4 / 7}, \mathrm{C}_{12} \mathrm{H}_{8} \mathrm{~N}_{2}\right), 140.4\left(1 \mathrm{C}, \mathrm{C}^{4-7}, \mathrm{C}_{9} \mathrm{H}_{6}\right)$, $141.4\left(1 \mathrm{C}, \mathrm{C}^{4 / 7}, \mathrm{C}_{12} \mathrm{H}_{8} \mathrm{~N}_{2}\right), 147.4,148.6\left(2 \times 1 \mathrm{C}_{\mathrm{q}}, \mathrm{C}^{3 \mathrm{a}, 7 \mathrm{a}}, \mathrm{C}_{9} \mathrm{H}_{6}\right), 147.9$ $\left(1 \mathrm{C}, \mathrm{C}^{6}, \mathrm{C}_{4} \mathrm{H}_{5} \mathrm{~N}\right), 153.8\left(1 \mathrm{C}, \mathrm{C}^{2 / 9}, \mathrm{C}_{12} \mathrm{H}_{8} \mathrm{~N}_{2}\right), 158.5\left(1 \mathrm{C}, \mathrm{C}^{2 / 9}, \mathrm{C}_{12} \mathrm{H}_{8} \mathrm{~N}_{2}\right)$, $163.5\left(1 \mathrm{C}_{\mathrm{q}}, \mathrm{C}^{2}, \mathrm{C}_{4} \mathrm{H}_{5} \mathrm{~N}\right), 224.7,222.4(2 \times 1 \mathrm{C}, \mathrm{CO}) . \mathrm{IR}\left(\mathrm{ATR} ; \mathrm{cm}^{-1}\right): 1921$ vs $\left[\mathrm{v}_{\mathrm{a}}(\mathrm{CO})\right], 1861$ vs $\left[\mathrm{v}_{\mathrm{s}}(\mathrm{CO})\right], 1030$ vs-br $[\mathrm{v}(\mathrm{BF})]$. Raman $\left(\mathrm{cm}^{-1}\right)$ : $1941(10)\left[v_{a}(C O)\right], 1846(5)\left[v_{s}(C O)\right]$. Single crystals of 15 suitable for $X-$ ray diffraction analysis were prepared by diffusion of $\mathrm{Et}_{2} \mathrm{O}$ into saturated solution of 15 in MeCN. When the reaction was carried out with 14-[D], 15-[D] was obtained, for which the signal at $5.51 \mathrm{ppm}$ in the ${ }^{1} \mathrm{H}$ NMR 
spectrum decreased in intensity (35\% of initial intensity) and that at 7.40 ppm was seen as a broadened singlet.

Synthesis of $\left[\mathrm{Me}_{4} \mathrm{~N}\right]\left[\left\{\eta^{3}: \kappa N-1-\left(\mathrm{C}_{5} \mathrm{H}_{4} \mathrm{NCH}_{2}\right) \mathrm{C}_{9} \mathrm{H}_{6}\right\} \mathrm{Mo}(\mathrm{CO})_{2} \mathrm{Cl}_{2}\right]$ (16). A solution of $14(1.05,2 \mathrm{mmol})$ in acetone $(5 \mathrm{~mL})$ was treated with $\left[\mathrm{Me}_{4} \mathrm{~N}\right] \mathrm{Cl}(440 \mathrm{mg}, 4 \mathrm{mmol})$. The reaction mixture was stirred at room temperature overnight. The volatiles were vacuum evaporated. The remaining solid was extracted with $\mathrm{CH}_{2} \mathrm{Cl}_{2}(7 \mathrm{~mL})$ and white precipitate of $\left[\mathrm{Me}_{4} \mathrm{~N}\right]\left[\mathrm{BF}_{4}\right]$ was filtrated off. The volatiles of the filtrate were vacuum evaporated. Crude product was recrystallized from $\mathrm{CH}_{2} \mathrm{Cl}_{2} / \mathrm{Et}_{2} \mathrm{O}$ and vacuum dried. Yield: $0.78 \mathrm{~g}(1.56 \mathrm{mmol}, 78 \%) . \mathrm{Mp}: 147^{\circ} \mathrm{C}$ (dec). Light orange crystals. Anal. Calcd. for $\mathrm{C}_{21} \mathrm{H}_{24} \mathrm{Cl}_{2} \mathrm{MoN}_{2} \mathrm{O}_{2}$ : C, $50.12 ; \mathrm{H}, 4.81$ $\mathrm{N}$, 5.57. Found: $\mathrm{C}, 50.04 ; \mathrm{H}, 4.88 ; \mathrm{N}, 5.43$. Negative-ion MS (MeCN): $\mathrm{m} / \mathrm{z}$ $=429(100 \%)[\mathrm{M}]^{-} .{ }^{1} \mathrm{H}$ NMR (acetone- $\left.\mathrm{d}_{6}, 500.20 \mathrm{MHz}\right): \delta=3.43(\mathrm{~s}, 12 \mathrm{H}$, $\left.\left(\mathrm{CH}_{3}\right)_{4} \mathrm{~N}\right), 3.74,4.04\left(2 \times \mathrm{d},{ }^{2} \mathrm{~J}\left({ }^{1} \mathrm{H},{ }^{1} \mathrm{H}\right)=19.1 \mathrm{~Hz}, 2 \mathrm{H}, \mathrm{CH}_{2}\right), 4.58$ $\left(\mathrm{d},{ }^{3} \mathrm{~J}\left({ }^{1} \mathrm{H},{ }^{1} \mathrm{H}\right)=3.9 \mathrm{~Hz}, 1 \mathrm{H}, \mathrm{H}^{3}, \mathrm{C}_{9} H_{5}\right), 6.24-6.37\left(\mathrm{~m}, 4 \mathrm{H}, \mathrm{H}^{4-7}, \mathrm{C}_{9} H_{6}\right)$, $6.88\left(\mathrm{~d},{ }^{3} \mathrm{~J}\left({ }^{1} \mathrm{H},{ }^{1} \mathrm{H}\right)=3.9 \mathrm{~Hz}, 1 \mathrm{H}, \mathrm{H}^{2}, \mathrm{C}_{9} \mathrm{H}_{6}\right), 7.14\left(\mathrm{dd},{ }^{3} \mathrm{~J}\left({ }^{1} \mathrm{H},{ }^{1} \mathrm{H}\right)=7.6\right.$ $\left.\mathrm{Hz},{ }^{3} \mathrm{~J}\left({ }^{1} \mathrm{H},{ }^{1} \mathrm{H}\right)=5.6 \mathrm{~Hz}, 1 \mathrm{H}, \mathrm{H}^{5}, \mathrm{C}_{5} \mathrm{H}_{4} \mathrm{~N}\right), 7.47\left(\mathrm{~d},{ }^{3} \mathrm{~J}\left({ }^{1} \mathrm{H},{ }^{1} \mathrm{H}\right)=7.8 \mathrm{~Hz}, 1 \mathrm{H}\right.$, $\left.\mathrm{H}^{3}, \mathrm{C}_{5} \mathrm{H}_{4} \mathrm{~N}\right), 7.77\left(\mathrm{ddd},{ }^{3} \mathrm{~J}\left({ }^{1} \mathrm{H},{ }^{1} \mathrm{H}\right)=7.8 \mathrm{~Hz},{ }^{3} \mathrm{~J}\left({ }^{1} \mathrm{H},{ }^{1} \mathrm{H}\right)=7.6 \mathrm{~Hz},{ }^{4} \mathrm{~J}\left({ }^{1} \mathrm{H},{ }^{1} \mathrm{H}\right)=\right.$ $\left.1.7 \mathrm{~Hz}, 1 \mathrm{H}, \mathrm{H}^{4}, \mathrm{C}_{5} \mathrm{H}_{4} \mathrm{~N}\right), 8.58\left(\mathrm{dd},{ }^{3} \mathrm{~J}\left({ }^{1} \mathrm{H},{ }^{1} \mathrm{H}\right)=5.6 \mathrm{~Hz},{ }^{4} \mathrm{~J}\left({ }^{1} \mathrm{H},{ }^{1} \mathrm{H}\right)=1.5\right.$ $\left.\mathrm{Hz}, 1 \mathrm{H}, \mathrm{H}^{6}, \mathrm{C}_{5} \mathrm{H}_{4} \mathrm{~N}\right)$. IR $\left(\mathrm{ATR} ; \mathrm{cm}^{-1}\right): 1928$ vs [v $\left.(\mathrm{CO})\right], 1842$ vs [v $\left.(\mathrm{CO})\right]$. Single crystals of $16 \cdot{ }_{2} \mathrm{Me}_{2} \mathrm{CO}$ suitable for $\mathrm{X}$-ray diffraction analysis were prepared by diffusion of $\mathrm{Et}_{2} \mathrm{O}$ into saturated solution of $\mathbf{1 6}$ in acetone. When the reaction was carried out with 14-[D], 16-[D] was obtained, for which the signal at $4.58 \mathrm{ppm}$ in the ${ }^{1} \mathrm{H}$ NMR spectrum decreased in intensity ( $35 \%$ of initial intensity) and that at $6.88 \mathrm{ppm}$ was seen as a broadened singlet.

\section{Synthesis} of $\left[\left\{\eta^{3}: K N-1-\left(\mathrm{C}_{5} \mathrm{H}_{4} \mathrm{NCH}_{2}\right)-3\right.\right.$ $\left.\left(\mathrm{C}_{5} \mathrm{H}_{4} \mathrm{NHCH}_{2}\right) \mathrm{C}_{9} \mathrm{H}_{5}\right\} \mathrm{Mo}(\mathrm{CO})_{2}\left(\mathrm{NCMe}_{2}\right]\left[\mathrm{BF}_{4}\right]_{2}$ (17). A solution of 9 $(0.98 \mathrm{~g}, 2 \mathrm{mmol})$ in $\mathrm{MeCN}(5 \mathrm{~mL})$ was cooled at $0^{\circ} \mathrm{C}$ and treated with $\mathrm{HBF}_{4} \cdot \mathrm{Et}_{2} \mathrm{O}(0.82 \mathrm{~mL}, 6 \mathrm{mmol})$ dropwise. The reaction mixture was stirred at room temperature overnight. The volatiles were vacuum evaporated and remaining solid was washed with $\mathrm{Et}_{2} \mathrm{O}(5 \mathrm{~mL})$ and $\mathrm{CH}_{2} \mathrm{Cl}_{2}(5 \mathrm{~mL})$. Crude product was recrystallized from $\mathrm{MeCN} / \mathrm{Et}_{2} \mathrm{O}$ and vacuum dried. Yield: $1.08 \mathrm{~g}(1.54 \mathrm{mmol}, 77 \%)$. Red crystals. Mp: $133^{\circ} \mathrm{C}$ (dec). Anal. Calcd. for $\mathrm{C}_{27} \mathrm{H}_{23} \mathrm{~B}_{2} \mathrm{~F}_{8} \mathrm{MoN}_{4} \mathrm{O}_{2}$ : C, 46.00; $\mathrm{H}, 3.29 ; \mathrm{N}, 4.75$. Found: C, 45.88; $\mathrm{H}, 3.32 ; \mathrm{N}, 4.84 .{ }^{1} \mathrm{H}$ NMR $\left(\mathrm{CD}_{3} \mathrm{CN}, 400.13 \mathrm{MHz}\right): \delta=$ 4.05, $4.33\left(2 \times \mathrm{d},{ }^{2} \mathrm{~J}\left({ }^{1} \mathrm{H},{ }^{1} \mathrm{H}\right)=19.9 \mathrm{~Hz}, 2 \mathrm{H}, \mathrm{C}_{5} \mathrm{H}_{4} \mathrm{NCH}_{2}\right), 4.18\left(\mathrm{ABq}, \Delta \delta_{\mathrm{AB}}\right.$ $\left.=0.04 \mathrm{ppm},{ }^{2} \mathrm{~J}\left({ }^{1} \mathrm{H},{ }^{1} \mathrm{H}\right)=16.9 \mathrm{~Hz}, 2 \mathrm{H}, \mathrm{C}_{5} \mathrm{H}_{4} \mathrm{NHCH}_{2}\right), 6.33\left(\mathrm{~d},{ }^{3} \mathrm{~J}\left({ }^{1} \mathrm{H},{ }^{1} \mathrm{H}\right)=\right.$ $\left.7.2 \mathrm{~Hz}, 1 \mathrm{H}, \mathrm{H}^{4 / 7}, \mathrm{C}_{9} \mathrm{H}_{5}\right), 6.45\left(\mathrm{dd},{ }^{3} \mathrm{~J}\left({ }^{1} \mathrm{H},{ }^{1} \mathrm{H}\right)=7.5 \mathrm{~Hz},{ }^{3} \mathrm{~J}\left({ }^{1} \mathrm{H},{ }^{1} \mathrm{H}\right)=7.3 \mathrm{~Hz}\right.$, $\left.1 \mathrm{H}, \mathrm{H}^{5 / 6}, \mathrm{C}_{9} \mathrm{H}_{5}\right), 6.58\left(\mathrm{dd},{ }^{3} \mathrm{~J}\left({ }^{1} \mathrm{H},{ }^{1} \mathrm{H}\right)=7.5 \mathrm{~Hz},{ }^{3} \mathrm{~J}\left({ }^{1} \mathrm{H},{ }^{1} \mathrm{H}\right)=7.2 \mathrm{~Hz}, 1 \mathrm{H}, \mathrm{H}^{5 / 6}\right.$ $\left.\mathrm{C}_{9} H_{5}\right), 6.64\left(\mathrm{~d},{ }^{3} \mathrm{~J}\left({ }^{1} \mathrm{H},{ }^{1} \mathrm{H}\right)=7.1 \mathrm{~Hz}, 1 \mathrm{H}, \mathrm{H}^{4 / 7}, \mathrm{C}_{9} H_{5}\right), 7.18\left(\mathrm{~s}, 1 \mathrm{H}, \mathrm{H}^{2}\right.$, $\left.\mathrm{C}_{9} \mathrm{H}_{5}\right), 7.29-7.55\left(\mathrm{~m}, 4 \mathrm{H}\right.$ of $\mathrm{C}_{5} \mathrm{H}_{4} \mathrm{~N}$ and $4 \mathrm{H}$ of $\left.\mathrm{C}_{5} \mathrm{H}_{4} \mathrm{NH}\right), 13.1(\mathrm{~m}, 1 \mathrm{H}$, $\left.\mathrm{C}_{5} \mathrm{H}_{4} \mathrm{NH}\right)$. IR (ATR; $\left.\mathrm{cm}^{-1}\right)$ : 1958 vs [ $\left.\mathrm{v}_{\mathrm{a}}(\mathrm{CO})\right], 1873$ vs [ $\left.\mathrm{v}_{\mathrm{s}}(\mathrm{CO})\right]$.

Synthesis of $\left[\left\{\eta^{3}: K N, N-1,3-\left(\mathrm{C}_{5} \mathrm{H}_{4} \mathrm{NCH}_{2}\right)_{2} \mathrm{C}_{9} \mathrm{H}_{5}\right\} \mathrm{Mo}(\mathrm{CO})_{2}(\mathrm{NCMe})\right]\left[\mathrm{BF}_{4}\right]$ (18). Complex $17(0.49,1 \mathrm{mmol})$ was dissolved in pyridine $(5 \mathrm{~mL})$. The reaction mixture was stirred at room temperature overnight. The excess of the pyridine was vacuum evaporated and remaining solid was extracted with $\mathrm{CH}_{2} \mathrm{Cl}_{2}(7 \mathrm{~mL})$. The white precipitate of the pyridinium salt was filtrated off and volatiles of the filtrate were vacuum evaporated. Crude product was recrystallized from $\mathrm{MeCN} / \mathrm{Et}_{2} \mathrm{O}$ and vacuum dried. Yield: $0.27 \mathrm{~g}(0.46 \mathrm{mmol}, 46 \%)$. Red crystals. $\mathrm{Mp}: 137{ }^{\circ} \mathrm{C}$ (dec). Anal. Calcd. for $\mathrm{C}_{25} \mathrm{H}_{20} \mathrm{BF}_{4} \mathrm{MoN}_{3} \mathrm{O}_{2}$ : C, 52.02; $\mathrm{H}, 3.49 ; \mathrm{N}, 7.28$. Found: $\mathrm{C}$, 52.10; H, 3.41; N, 7.44. Positive-ion MS (MeCN): 492 (100\%) [M] $]^{+}, 464$ $\left[\mathrm{M}-\mathrm{CO}^{+}, 451[\mathrm{M}-\mathrm{MeCN}]^{+}, 423[\mathrm{M}-\mathrm{CO}-\mathrm{MeCN}]^{+}, 395[\mathrm{M}-2 \mathrm{CO}-\right.$ $\mathrm{MeCN}]^{+} .{ }^{1} \mathrm{H}$ NMR $\left(\mathrm{CD}_{3} \mathrm{CN}, 500.20 \mathrm{MHz}\right): \delta=4.04,4.31\left(2 \times \mathrm{d},{ }^{3} \mathrm{~J}\left({ }^{1} \mathrm{H},{ }^{1} \mathrm{H}\right)\right.$ $\left.=19.6 \mathrm{~Hz}, 4 \mathrm{H}, \mathrm{CH}_{2}\right), 6.38\left(\mathrm{~s}, 1 \mathrm{H}, \mathrm{H}^{2}, \mathrm{C}_{9} H_{5}\right), 6.58\left(\mathrm{~m}, 4 \mathrm{H}, \mathrm{H}^{4-7}, \mathrm{C}_{9} H_{5}\right)$, $7.34\left(\mathrm{dd},{ }^{3} \mathrm{~J}\left({ }^{1} \mathrm{H},{ }^{1} \mathrm{H}\right)=7.6 \mathrm{~Hz},{ }^{3} \mathrm{~J}\left({ }^{1} \mathrm{H},{ }^{1} \mathrm{H}\right)=5.8 \mathrm{~Hz}, 2 \mathrm{H}, \mathrm{H}^{5}, \mathrm{C}_{5} \mathrm{H}_{4} \mathrm{~N}\right), 7.60$ $\left(\mathrm{d},{ }^{3} \mathrm{~J}\left({ }^{1} \mathrm{H},{ }^{1} \mathrm{H}\right)=8.0 \mathrm{~Hz}, 2 \mathrm{H}, \mathrm{H}^{3}, \mathrm{C}_{5} \mathrm{H}_{4} \mathrm{~N}\right), 7.90\left(\mathrm{dd},{ }^{3} \mathrm{~J}\left({ }^{1} \mathrm{H},{ }^{1} \mathrm{H}\right)=8.0\right.$ $\left.\mathrm{Hz},{ }^{3} \mathrm{~J}\left({ }^{1} \mathrm{H},{ }^{1} \mathrm{H}\right)=7.6 \mathrm{~Hz}, 2 \mathrm{H}, \mathrm{H}^{4}, \mathrm{C}_{5} \mathrm{H}_{4} \mathrm{~N}\right), 8.05\left(\mathrm{~d},{ }^{3} \mathrm{~J}\left({ }^{1} \mathrm{H},{ }^{1} \mathrm{H}\right)=5.8 \mathrm{~Hz} ; 2 \mathrm{H}\right.$, $\left.\mathrm{H}^{6}, \mathrm{C}_{5} \mathrm{H}_{4} \mathrm{~N}\right)$. IR $\left(\mathrm{ATR} ; \mathrm{cm}^{-1}\right)$ : 1952 vs $\left[\mathrm{v}_{\mathrm{a}}(\mathrm{CO})\right], 1874$ vs [ $\left.\mathrm{v}_{\mathrm{s}}(\mathrm{CO})\right]$. Single crystals of 18 suitable for $\mathrm{X}$-ray diffraction analysis were prepared by diffusion of $\mathrm{Et}_{2} \mathrm{O}$ into saturated solution of $\mathbf{1 4} \mathrm{in} \mathrm{MeCN}$.

Synthesis of $\left[\left\{\eta^{3}: K N, N-1,3-\left(\mathrm{C}_{5} \mathrm{H}_{4} \mathrm{NCH}_{2}\right)_{2} \mathrm{C}_{9} \mathrm{H}_{5}\right\} \mathrm{Mo}(\mathrm{CO})_{2} \mathrm{Cl}\right]$ (19). A solution of $17(0.58 \mathrm{~g}, 1 \mathrm{mmol})$ in acetone $(5 \mathrm{~mL})$ was treated with
$\left[\mathrm{Me}_{4} \mathrm{~N}\right] \mathrm{Cl}(0.11 \mathrm{~g}, 1 \mathrm{mmol})$. The reaction mixture was stirred at room temperature overnight. The light brown solution was decanted. Remaining orange precipitate was washed with methanol $(3 \times 5 \mathrm{~mL})$ and vacuum dried. Yield: $0.38 \mathrm{~g}(0.78 \mathrm{mmol}, 78 \%)$. Orange crystals. Mp: $139{ }^{\circ} \mathrm{C}$ (dec). Anal. Calcd. for $\mathrm{C}_{23} \mathrm{H}_{17} \mathrm{ClMoN}_{2} \mathrm{O}_{2}$ : C, 56.98; $\mathrm{H}, 3.54 ; \mathrm{N}$, 5.78. Found: $\mathrm{C}, 57.18 ; \mathrm{H}, 3.45 ; \mathrm{N}, 5.65 .{ }^{1} \mathrm{H}$ NMR (DMSO- $\mathrm{d}_{6}, 500.20$ $\mathrm{MHz}): \delta=3.82,4.21\left(2 \times \mathrm{d},{ }^{3} \mathrm{~J}\left({ }^{1} \mathrm{H},{ }^{1} \mathrm{H}\right)=19.4 \mathrm{~Hz}, 4 \mathrm{H}, \mathrm{CH}_{2}\right), 6.26(\mathrm{~s}, 1 \mathrm{H}$, $\left.\mathrm{H}^{2}, \mathrm{C}_{9} H_{5}\right), 6.46\left(\mathrm{~m}, 4 \mathrm{H}, \mathrm{H}^{4-7}, \mathrm{C}_{9} H_{5}\right), 7.37\left(\mathrm{dd},{ }^{3} \mathrm{~J}\left({ }^{1} \mathrm{H},{ }^{1} \mathrm{H}\right)=7.4\right.$ $\left.\mathrm{Hz},{ }^{3} \mathrm{~J}\left({ }^{1} \mathrm{H},{ }^{1} \mathrm{H}\right)=5.6 \mathrm{~Hz}, 2 \mathrm{H}, \mathrm{H}^{5}, \mathrm{C}_{5} \mathrm{H}_{4} \mathrm{~N}\right), 7.62\left(\mathrm{~d},{ }^{3} \mathrm{~J}\left({ }^{1} \mathrm{H},{ }^{1} \mathrm{H}\right)=7.7 \mathrm{~Hz}, 2 \mathrm{H}\right.$, $\left.\mathrm{H}^{3}, \mathrm{C}_{5} \mathrm{H}_{4} \mathrm{~N}\right), 7.91$ (ddd, ${ }^{3} \mathrm{~J}\left({ }^{1} \mathrm{H},{ }^{1} \mathrm{H}\right)=7.7 \mathrm{~Hz},{ }^{3} \mathrm{~J}\left({ }^{1} \mathrm{H},{ }^{1} \mathrm{H}\right)=7.4 \mathrm{~Hz},{ }^{4} \mathrm{~J}\left({ }^{1} \mathrm{H},{ }^{1} \mathrm{H}\right)=$ $\left.1.6 \mathrm{~Hz}, 2 \mathrm{H}, \mathrm{H}^{4}, \mathrm{C}_{5} \mathrm{H}_{4} \mathrm{~N}\right), 8.38\left(\mathrm{dd},{ }^{3} \mathrm{~J}\left({ }^{1} \mathrm{H},{ }^{1} \mathrm{H}\right)=5.6 \mathrm{~Hz} ;{ }^{4} \mathrm{~J}\left({ }^{1} \mathrm{H},{ }^{1} \mathrm{H}\right)=1.3 \mathrm{~Hz}\right.$; $\left.2 \mathrm{H}, \mathrm{H}^{6}, \mathrm{C}_{5} \mathrm{H}_{4} \mathrm{~N}\right)$. IR (ATR; $\left.\mathrm{cm}^{-1}\right): 1935$ vs [va(CO)], 1862 vs $\left[\mathrm{v}_{\mathrm{s}}(\mathrm{CO})\right]$, 1850 vs $\left[v_{s}(C O)\right]$

X-ray crystallography: The $\mathrm{X}$-ray data for the crystals of the compounds $4,7,9,10,11,12,13,14 \cdot \mathrm{CH}_{2} \mathrm{Cl}_{2}, 15,16 \cdot{ }_{1}{ }_{2} \mathrm{Me}_{2} \mathrm{CO}$ and 18 were obtained at $150 \mathrm{~K}$ using an Oxford Cryostream low-temperature device on a Nonius KappaCCD diffractometer with Mo Ka radiation $(\lambda=0.71073$ $\AA$ ) and a graphite monochromator. Data reductions were performed with DENZO-SMN. ${ }^{[34]}$ The absorption was corrected by integration methods. ${ }^{[35]}$ Structures were solved by direct methods (Sir92) ${ }^{[36]}$ and refined by full-matrix least squares based on $F^{2}$ (SHELXL97). ${ }^{[37]}$ Hydrogen atoms were mostly localized on a difference Fourier map. However, to ensure uniformity of the treatment of the crystal, all hydrogen atoms were recalculated into idealized positions (riding model) and assigned temperature factors $U_{\text {iso }}(\mathrm{H})=1.2\left[U_{\text {eq }}\right.$ (pivot atom) $]$ or $1.5 U_{\text {eq }}$ for the methyl moiety with $\mathrm{C}-\mathrm{H}=0.96,0.97$, and $0.93 \AA$ for methyl, methylene, and hydrogen atoms in aromatic rings or the allyl moiety, respectively Thermal ellipsoids of fluorine atoms of tetrafluoroborate anion in $\mathbf{1 1}$ were improved with standard ISOR instruction implemented in SHELXL97 software. ${ }^{[37]}$ In 10 , the same problem was solved by splitting of four fluorine atoms to two positions with nearly equal occupancy by using SAME, RIGU and EADP instructions in SHELXL-2013. ${ }^{[38]}$ There are residual electron maxima and small cavities within the unit cell probably originated from the disordered solvent (acetonitrile) in the structure of $\mathbf{1 5}$. PLATON/SQUEZZE ${ }^{[39]}$ was used to correct the data for the presence of disordered solvent. A potential solvent volume of $306 \AA^{3}$ was found. 78 electrons per unit cell worth of scattering were located in the void. The calculated stoichiometry of solvent was calculated to be three molecules of acetonitrile per unit cell which results in 66 electrons per unit cell. The same procedure was used for structure of $\mathbf{1 4}$ resulting in a potential solvent volume of $100 \AA^{3}$ and 46 electrons. The calculated stoichiometry of solvent was calculated to be one molecule of dichloromethane per unit cell which results in 42 electrons per unit cell. Moreover, the fluorine atoms in disordered tetrafluoroborate anion were split into two positions with occupancy 7:3. CCDC 1486921-1486931 contain the supplementary crystallographic data for this paper. These data can be obtained free of charge from The Cambridge Crystallographic Data Centre.

Computational details: All calculations were performed with the GAUSSIAN 09 software package ${ }^{[40]}$ using the B3LYP gradient-corrected exchange-correlation functional ${ }^{[41]}$ in combination with the LanL2TZ basis set ${ }^{[42]}$ augmented with an f-polarization function ${ }^{[43]}$ for Mo and the standard $6-31 G(d, p)$ basis set ${ }^{[44]}$ for the remaining elements. The geometry optimizations were carried out without symmetry constrains. Transition state optimizations were performed with synchronous transitguided quasi-Newton method (STQN). ${ }^{[45]}$ Frequency calculations were performed to confirm the nature of minima and stationary points. One imaginary frequency was observed for each transition state and none for minima. Each transition state was further confirmed by following the intrinsic reaction coordinate (IRC) on both sides. ${ }^{[46]}$ The solvent effects were considered in all energy calculations using polarizable continuum model $(\mathrm{PCM}){ }^{[47]}$ The free energy changes at $298.15 \mathrm{~K}$ were then calculated from equation: $\Delta G=\Delta H-T \Delta S$.

\section{Acknowledgements}


This work was supported by Ministry of Education of the Czech Republic (Project no. SG350004). Access to computing and storage facilities owned by parties and projects contributing to the National Grid Infrastructure MetaCentrum, provided under the programme "Projects of Large Research, Development, and Innovations Infrastructures" (CESNET LM2015042), is greatly appreciated.

Keywords: hapticity $\bullet$ cyclopentadienyl $\bullet$ indenyl $\bullet$ molybdenum - intramolecular coordination

[1] T. J. Kealy, P. L. Pauson, Nature 1951, 168, 1039-1040; E. O. Fischer, W. Pfab, Z. Naturforsch. B 1952, 7, 377-379; S. A. Miller, J. A. Tebboth, J. F. Tremaine, J. Chem. Soc. 1952, 632-635; H. Werner, Angew. Chem. Int. Ed. 2012, 51, 6052-6058.

[2] B. Topolinski, B. M. Schmidt, S. Higashibayashi, H. Sakurai, D. Lentz, Dalton Trans. 2013, 42, 13809-13812; J. M. Speck, M. Korb, A. Schade S. Spange, H. Lang, Organometallics 2015, 34, 3788-3798; C. He, J. Wang, Z. Gu, J. Org. Chem. 2015, 80, 7865-7875; W. Geng, C. Wang, J. Guang, W. Hao, W. X. Zhang, Z. Xi, Chem. Eur. J. 2013, 19, 8657 8664; A. Donoli, A. Bisello, R. Cardena, M. Crisma, L. Orian, S. Santi, Organometallics 2015, 34, 4451-4463; A. Zirakzadeh, A. Herlein, M. A. Groß, K. Mereiter, Y. Wang, W. Weissensteiner, Organometallics 2015, 34, 3820-3832; M. Roemer, K. Y. Kang, Y. K. Chung, D. Lentz, Chem. Eur. J. 2012, 18, 3371-3389; Y. Yan, T. M. Deaton, J. Zhang, H. He, J. Hayat, P. Pageni, K. Matyjaszewski, C. Tang, Macromolecules 2015 , 48, 1644-1650; S. Ursillo, D. Can, H. W. P. N'Dongo, P. Schmutz, B. Spingler, R. Alberto, Organometallics 2014, 33, 6945-6952; A. R. Petrov, K. Jess, M. Freytag, P. G. Jones, M. Tamm, Organometallics 2013, 32, 5946-5954.

[3] J. Schejbal, J. Honzíček, J. Vinklárek, M. Erben, Z. Růžičková, Eur. J. Inorg. Chem. 2014, 5895-5907; W. Y. Wang, N. N. Ma, S. L. Sun, Y. Q. Qiu, Phys. Chem. Chem. Phys. 2014, 16, 4900-4910; X. Wang, D. Li, W. Deuther-Conrad, J. Lu, Y. Xie, B. Jia, M. Cui, J. Steinbach, P. Brust B. Liu, H. Jia, J. Med. Chem. 2014, 57, 7113-7125; H. Li, H. Zhang, Q. Zhang, Q. W. Zhang, D. H. Qu, Org. Lett. 2012, 14, 5900-5903; Z. Liu, A. Habtemariam, A. M. Pizarro, S. A. Fletcher, A. Kisova, O. Vrana, L. Salassa, P. C. A. Bruijnincx, G. J. Clarkson, V. Brabec, P. J. Sadler, J. Med. Chem. 2011, 54, 3011-3026; G. Jaouen, A. Vessieres, S. Top Chem. Soc. Rev. 2015, 44, 8802-8817; Y. Yokota, Y. Mino, Y. Kanai, T. Utsunomiya, A. Imanishi, K. Fukui, J. Phys. Chem. C 2015, 119, 1846718480; A. Schmied, A. Straube, T. Grell, S. Jähnigen, E. Hey-Hawkins, Dalton Trans. 2015, 44, 18760-18768.

[4] B. Ye, N. Cramer, Science 2012, 338, 504-506; B. Ye, N. Cramer, J. Am. Chem. Soc. 2013, 135, 636-639; K. Sünkel, S. Weigand, A. Hoffmann, S. Blomeyer, C. G. Reuter, Y. V. Vishnevskiy, N. W. Mitzel, J. Am. Chem. Soc. 2015, 137, 126-129; S. Harder, D. Naglav, C. Ruspic, C. Wickleder, M. Adlung, W. Hermes, M. Eul, R. Pöttgen, D. B. Rego, F. Poineau, K. R. Czerwinski, R. H. Herber, I. Nowik, Chem. Eur. J. 2013 19, 12272-12280; L. D. Field, C. M. Lindall, A. F. Masters, G. K. B. Clentsmith, Coord. Chem. Rev. 2011, 255, 1733-1790; M. Erben, D. Veselý, J. Vinklárek, J. Honzíček, J. Mol. Catal. A: Chem. 2012, 353354, 13-21; S. Heinl, M. Scheer, Chem. Sci. 2014, 5, 3221-3225; T. Liu, X. Wang, C. Hoffmann, D. L. DuBois, M. R. Bullock, Angew. Chem. Int. Ed. 2014, 53, 5300-5304; M. Fang, E. S. Wiedner, W. G. Dougherty, W. S. Kassel, T. Liu, D. L. DuBois, M. R. Bullock, Organometallics 2014 33, 5820-5833; A. Iordache, M. Oltean, A. Milet, F. Thomas, B. Baptiste, E. Saint-Aman, C. Bucher, J. Am. Chem. Soc. 2012, 134, 2653-2671; D.
Patel, A. Wooles, A. D. Cornish, L. Steven, E. S. Davies, D. J. Evans, J. McMaster, W. Lewis, A. J. Blake, S. T. Liddle, Dalton Trans. 2015, 44, 14159-14177.

[5] A. J. Hart-Davis, R. J. Mawby, J. Chem. Soc. A 1969, 2403-2407.

[6] M. J. Calhorda, C. C. Romăo, L. F. Veiros, Chem. Eur. J. 2002, 8, 868875.

[7] A. J. Hart-Davis, C. White, R. J. Mawby, Inorg. Chim. Acta 1970, 4 441-446; D. J. Jones, R. J. Mawby, Inorg. Chim. Acta 1972, 6, 157-160.

[8] C. A. Bradley, I. Keresztes, E. Lobkovsky, V. G. Young, P. J. Chirik, J. Am. Chem. Soc. 2004, 126, 16937-16950; L. F. Veiros, J. Honzíček, C. C. Romão, M. J. Calhorda, Inorg. Chim. Acta 2010, 363, 555-561.

[9] L. F. Veiros, M. J. Calhorda, Dalton Trans. 2011, 40, 11138-11146.

[10] M. J. Calhorda, C. A. Gamelas, I. S. Gonçalves, E. Herdtweck, C. C. Romão, L. F. Veiros, Organometallics 1998, 17, 2597-2611.

[11] C. A. Gamelas, N. A. G. Bandeira, C. C. L. Pereira, M. J. Calhorda, E. Herdtweck, M. Machuqueiro, C. C. Romão, L. F. Veiros, Dalton Trans. 2011, 10513-10525

[12] J. Lodinský, J. Vinklárek, L. Dostál, Z. Růžičková, J. Honziččk, RSC Adv. 2015, 5, 27140-27153

[13] J. Honziček, J. Vinklárek, M. Erben, J. Lodinský, L. Dostál, Z Padělková, Organometallics 2013, 32, 3502-3511.

[14] C. C. Romão, Appl. Organomet. Chem. 2000, 14, 539-548.

[15] J. W. Faller, C. C. Chen, M. J. Mattina, A. Jakubowski, J. Organomet. Chem. 1973, 52, 361-386.

[16] P. R. Mitchell, R. V. Parish, Journal of Chemical Education 1969, 46 , 811-814; I. Langmuir, Science 1921, 54, 59-67.

[17] T. F. Wang, T. Y. Lee, J. W. Chou, C. W. Ong, J. Organomet. Chem. 1992, 423, 31-38.

[18] A. Avey, T. J. R. Weakley, D. R. Tyler, J. Am. Chem. Soc. 1993, 115 7706-7715.

[19] O. Mrózek, L. Šebestová, J. Vinklárek, M. Řezáčová, A. Eisner, Z. Růžičková, J. Honzíček, Eur. J. Inorg. Chem. 2016, accepted.

[20] S. M. Bruno, A. C. Gomes, C. A. Gamelas, M. Abrantes, M. C. Oliveira, A. A. Valente, F. A. A. Paz, M. Pillinger, C. C. Romão, I. S. Gonçalves, New J. Chem. 2014, 38, 3172-3180; A. C. Gomes, C. A. Gamelas, J. A. Fernandes, F. A. A. Paz, P. Nunes, M. Pillinger, I. S. Gonçalves, C. C. Romão, M. Abrantes, Eur. J. Inorg. Chem. 2014, 3681-3689; J. Honziček, I. Honzičková, J. Vinklárek, Z. Růžičková, J. Organomet. Chem. 2014, 772-773, 299-306.

[21] Y. Pan, W. Rong, Z. Jian, D. Cui, Macromolecules 2012, 45, 1248 1253; S. Wang, Y. Feng, L. Mao, E. Sheng, G. Yang, M. Xie, S. Wang, Y. Wei, Z. Huang, J. Organomet. Chem. 2006, 691, 1265-1274; C. Qian, H. Li, J. Sun, W. Nie, J. Organomet. Chem. 1999, 585, 59.

[22] C. J. Wu, S. H. Lee, S. T. Yu, S. J. Na, H. Yun, B. Y. Lee Organometallics 2008, 27, 3907-3917; Z. Ziniuk, I. Goldberg, M. Kol, J. Organomet. Chem. 1997, 545-546, 441-446; M. L. Buil, M. A. Esteruelas, A. M. López, A. C. Mateo, E. Onate, Organometallics 2007 26, 554-565.

[23] L. F. Groux, D. Zargarian, Organometallics 2003, 22, 3124-3133.

[24] J. W. Faller, R. H. Crabtree, A. Habib, Organometallics 1985, 4, 929935.

[25] J. R. Ascenso, I. S. Gonçalves, E. Herdtweck, C. C. Romão, J. Organomet. Chem. 1996, 508, 169-181.

[26] M. J. Calhorda, L. F. Veiros, Coord. Chem. Rev. 1999, 185-186, 37-51.

[27] J. Honziček, J. Vinklárek, Z. Padělková, L. Šebestová, K. Foltánová, M. Řezáčová, J. Organomet. Chem. 2012, 716, 258-268.

[28] K. B. Wiberg, Tetrahedron 1968, 24, 1083-1096. 
[29] W. L. F. Armarego, D. D. Perrin, in Purification of Laboratory Chemicals, Butterworth-Heinemann, Oxford, 1996.

[30] G. Wilkinson, Org. Synth., Coll. Vol 1963, 4, 473.

[31] L. Meurling, Acta Chem. Scand. B 1974, 28, 295-300.

[32] P. W. Hickmott, S. Wood, P. Murray-Rust, J. Chem. Soc., Perkin Trans. 1 1985, 2033-2038.

[33] P. W. Causey, M. C. Baird, S. P. C. Cole, Organometallics 2004, 23 , 4486-4494.

[34] Z. Otwinowski, W. Minor, Methods Enzymol. 1997, 276, 307-326.

[35] P. Coppens, in Crystallographic Computing (Eds.: F. R. Ahmed, S. R. Hall, C. P. Huber), Munksgaard, Copenhagen, 1970, pp. 255-270.

[36] A. Altomare, G. Cascarano, C. Giacovazzo, A. Guagliardi, M. C. Burla, G. Polidori, M. Camalli, J. Appl. Cryst. 1994, 27, 435-436.

[37] G. M. Sheldrick, in SHELXL97, University of Göttingen, Germany, 2008

[38] G. M. Sheldrick, Acta Cryst. C 2015, 71, 3-8.

[39] A. L. Spek, Acta Cryst. C 2015, 71, 9-18.

[40] M. J. Frisch, G. W. Trucks, H. B. Schlegel, G. E. Scuseria, M. A. Robb, J. R. Cheeseman, G. Scalmani, V. Barone, B. Mennucci, G. A Petersson, H. Nakatsuji, M. Caricato, X. Li, H. P. Hratchian, A. F. Izmaylov, J. Bloino, G. Zheng, J. L. Sonnenberg, M. Hada, M. Ehara, K. Toyota, R. Fukuda, J. Hasegawa, M. Ishida, T. Nakajima, Y. Honda, O. Kitao, H. Nakai, T. Vreven, J. Montgomery, J. A., J. E. Peralta, F. Ogliaro, M. Bearpark, J. J. Heyd, E. Brothers, K. N. Kudin, V. N. Staroverov, R. Kobayashi, J. Normand, K. Raghavachari, A. Rendell, J. C. Burant, S. S. lyengar, J. Tomasi, M. Cossi, N. Rega, N. J. Millam, M Klene, J. E. Knox, J. B. Cross, V. Bakken, C. Adamo, J. Jaramillo, R. Gomperts, R. E. Stratmann, O. Yazyev, A. J. Austin, R. Cammi, C. Pomelli, J. W. Ochterski, R. L. Martin, K. Morokuma, V. G. Zakrzewski, G. A. Voth, P. Salvador, J. J. Dannenberg, S. Dapprich, A. D. Daniels, Ö. Farkas, J. B. Foresman, J. V. Ortiz, J. Cioslowski, D. J. Fox, Gaussian, Inc., Wallingford CT, 2009.

[41] A. D. Becke, Physical Review A 1988, 38, 3098-3100; A. D. Becke, J. Chem. Phys. 1993, 98, 5648-5652; C. T. Lee, W. T. Yang, R. G. Parr, Phys. Rev. B 1988, 37, 785-789; B. Miehlich, A. Savin, H. Stoll, H. Preuss, Chem. Phys. Lett. 1989, 157, 200-206.

[42] L. E. Roy, P. J. Hay, R. L. Martin, J. Chem. Theory Comput. 2008, 4 , 1029-1031.; P. J. Hay, W. R. Wadt, J. Chem. Phys. 1985, 82, 299-310.

[43] A. W. Ehlers, M. Böhme, S. Dapprich, A. Gobbi, A. Höllwarth, V. Jonas, K. F. Köhler, R. Stegmann, A. Veldkamp, G. Frenking, Chem. Phys. Lett. 1993, 208, 111-114

[44] W. J. Hehre, R. Ditchfield, J. A. Pople, J. Chem. Phys. 1972, 56, 2257; P. C. Hariharan, J. A. Pople, Theor. Chem. Acc. 1973, 28, 213-222.

[45] C. Peng, H. B. Schlegel, Isr. J. Chem. 1994, 33, 449-454; C. Peng, P. Y. Ayala, H. B. Schlegel, M. J. Frisch, J. Comp. Chem. 1996, 17, 49-56.

[46] K. Fukui, Acc. Chem. Res. 1981, 14, 363-368; H. P. Hratchian, H. B. Schlegel, J. Chem. Phys. 2004, 120, 9918-9924

[47] J. Tomasi, B. Mennucci, R. Cammi, Chem. Rev. 2005, 105, 2999-3093. 


\section{FULL PAPER}

The unusual example of a low hapticity lock is reported on indenyl compounds with intramolecularly coordinated pyridine arms. The combined experimental and theoretical study reveals a high stability of $\eta^{3}: K N$ - and $\eta^{3}: K N, N$ coordination compounds toward $\eta^{3}$ to $\eta^{5}$ haptotropic rearrangement.

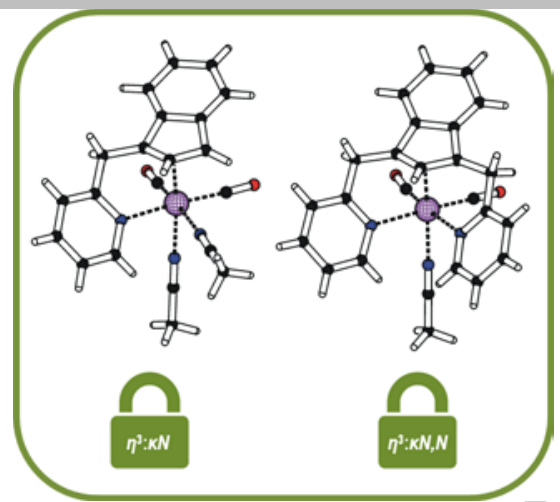

O. Mrózek, J. Vinklárek, Z. Růžičková, J. Honzíček*

Page No. - Page No.

Indenyl compounds with constrained hapticity: effect of strong intramolecular coordination. 